University of Florida Levin College of Law

UF Law Scholarship Repository

UF Law Faculty Publications

Faculty Scholarship

Winter 1997

\title{
Out Yet Unseen: A Racial Critique of Gay and Lesbian Legal Theory and Political Discourse
}

Darren Lenard Hutchinson

University of Florida Levin College of Law, hutchinson@law.ufl.edu

Follow this and additional works at: https://scholarship.law.ufl.edu/facultypub

Part of the Civil Rights and Discrimination Commons, Legal History Commons, and the Sexuality and the Law Commons

Recommended Citation

Darren Lenard Hutchinson, Out Yet Unseen: A Racial Critique of Gay and Lesbian Legal Theory and Political Discourse, 29 Conn. L. Rev. 561 (1997), available at http://scholarship.law.ufl.edu/facultypub/418

This Article is brought to you for free and open access by the Faculty Scholarship at UF Law Scholarship Repository. It has been accepted for inclusion in UF Law Faculty Publications by an authorized administrator of UF Law Scholarship Repository. For more information, please contact kaleita@law.ufl.edu. 


\section{CONNECTICUT \\ LAW REVIEW}

NUMBER 2

\section{Out Yet Unseen: A Racial Critique of Gay and Lesbian Legal Theory and Political Discourse}

\section{DARREN LENARD HUTCHINSON"}

i'm clear about why $i$ am and how $i$ am-i cannot extri-

cate the lesbian from my soul no more than $i$ could the chicana-i have always been both. ${ }^{1}$

I was mute, tongue-tied,

burdened by shadows and silence.

Now I speak

and my burden is lightened

lifted

free. $^{2}$

* B.A. University of Pennsylyania, 1990; J.D., Yale Law School, 1993; Law Clesk for Honorable Mary Johnson Lowe, United States District Court, Southem DLtrict of New York, 1994-1996. Presently, Assaciate, Cleary, Gottleb, Steen \& Hamllion I would like to thank Hubert L. Allen, Robin D. Bantes, I. Bennett Capers, Harlon L. Dalton, Bonnil Scott Jones, Terry Smith and James $Q$. Walker for their insightful comments on earliter versions of this Article.

1. Noomi Littlebear, Earth-Lover, Sunvivor, Musiclan, in ThS BRIDGe Called MY BACR: RADICAL WRITINGS BY WOMEN OF COLOR 157 (Chertic Moraga and Gloria Anzalduia eds., 1981) [hereinafter THIS BRIDGE CALIED MY BACK].

2. Marlon T. Riggs, Tongues Untied, in BROTHER to Brother: New Wammics By Black GaY MEN 200, 205 (Essex Hemphill ed., 1991) [hereinafter BROTHER TO BROTHER]. The original souree of this excerpt is Riggs' film Tongues Untled. MARLON T. RIGGs, TONGUES UNmED (1987) (dosumentary on black gay men) The film Tongues Untied presents postry of several authors. Marlon Riggs died on April 5, 1994, due to AIDS. Marlon Riggs Dles, Films Maker WWas 37, N.Y. TMES, Apr. 6, 1994, at B9. 


\section{INTRODUCTION: “TONGUES UNTIED”}

In the poem "Tongues Untied," Marlon T. Riggs, a black gay filmmaker and writer, recounts childhood confrontations with racism and homophobia. Riggs remembers being labelled a "nigger" and excluded by white students at Hepzibah Junior High in Augusta, Georgia, where he was "bused" at age twelve, and being called a "homo" by the older brother of a childhood friend. ${ }^{3}$ Through these "coming-of-age" experiences, a young Riggs learns to "[dis]claim"4 his marginalized racial and sexual statuses: he hides "deep inside [him]self where it is still. Silent, safe ...."

While living in the largely white gay and lesbian community of San Francisco, an adult Riggs begins to acknowledge his gay identity. Riggs, however, tries to ignore the "absence of black images" in the "Castro" or the fact that the "few" existing images-"joke, fetish, cartoon, caricature or disco diva adored from a distance ${ }^{p /}$-affirm racial hierarchy. Nevertheless, Riggs eventually learns that in the Castro, he is "an alien, unseen, and seen, unwanted."

The turning point in the poem-and in Riggs' lifo-occurs when, after persistent introspection and reclaiming of suppressed racial identity, Riggs escapes "delusion, pain, alienation, [and] silence" - and integrates (instead of treating as separate) his black and gay identities. Thus, at the poem's conclusion, the knots of silence and invisibility caused by interlocking racism and homophobia are "untied."

The symbolic meaning of the phrase "tongues untied" has grown to identify a small, yet expanding, cultural, intellectual, and artistic "movement" aimed at revealing-or ending the silence around-the interactions of race, class, gender, and sexuality, ${ }^{9}$ what one participant in the

3. Riggs, Tongues Untied, in BROTHER TO BROTHER, supra note 2, at 201.

4. Id.

5. Id. at 202.

6. Id. at 203.

7. Id.

8. Id. at 204.

9. See Introduction to TONGUES UNMED 7 (Martin Humphries ed., 1987) (explores racism, sexism and homophobia through poetry in order to "end $[$ the silence that has surrounded the lives of Black gay men.") While the phrase "tongues untied" has been associated primarily with work by black gay men, a broader and related movement has formed across racial and gender 
movement described as "the transformation of silence into language and action." The work of this movement contrasts starkly with that of the "dominant" gay and lesbian culture and scholarship, where issues of racial and class subordination are neglected or rejected and where a universal gay and lesbian experience is assumed. ${ }^{11}$ The work of this movement highlights the need for an examination of racial, gender, and class subordination within gay and lesbian political discourse and legal theory. These concerns, however, remain largely outside of traditional legal fora. ${ }^{12}$

lines. In fact, women of color published the earliest scholarship in this movement See, e.g., AFREKETE (Catherine E McKinley \& E Joyce DeLaney eds, 1995) (black lesbian anthology); BLACX MEN/WHTE MEN: A GAY ANTHOLOGY (Michael Smith ed, 1983) (black gay themes); KeTrH BOYKR, ONE MORE RTVER TO CROSS: BLACK AND GAY DN AMIERICA (1990) (same); THIS BRIDGE CALLED MY BACK, supra note 1 (Homen of color feministhesbian anthology); BROTHER TO BROTHER, supra note 2 (black gay themes); CIICANA LESBIANS: THE GRLS OUR MOTHERS WARNED US ABOUT (Carla Trujillo ed., 1991) (anthology) [hereinafter CrICANA LESBLANS]; CONGAŇERAs: LATnNA LESBIaNs (Juanita Ramos ed., 1987) (anthology); StEven Corbn, Fragments That RevenN (1993) (novel with black gay themes); MELVIN DIXON, VANISHNG ROOMS (1991) (novel with black gay themes); JEWELLE GOMEZ, FORTY-THREE SEPTEMBERS (1993) (essays with black lesbian themes); ESSEX HEMPHILL, CEREMONIES: PROSE AND POETRY (1992) (black gay themes) [hereinafter CERENoNIES]; HOME GIRLS: A BLACK FEIINIST ANTHOLOGY (Barbara Smilh cd., 1983) (black feminist/esbian anthology) [hereinafter HOME GIRLS]; IN THE LIFE A BLACK GAY ANTHOLOGY (Joseph Beam ed, 1986) Thereinafter IN THE LIFE]; RANDALL KENAN, A VISTTATION OF SPIPJTS (1989) (novel with black gay themes); AUDRE LORDE, SISTER OUTSIDER: ESSAYS AND SPEECHES thereinafier SISTER OUTSIDER] (1984) (black feministlesbian anthology); AUDRE LORDE, ZA3a: A NEW SPELING OF MY NAME (1982) (autobiography of black lesbian writer); A LOTUS OF ANOTHER COLOR: AN UNFOLORSG OF THE SOUTH ASLAN GAY AND LESBLAN EXPERIENCE (Rakesh Ratti ed, 1993) (anthology) Thereinafter A LOTUS OF ANOTHER COLOR]; PIECE OF MY HEART: A LESBIAN OF COLOUR ANTHOLOOY (MLAkeda Silvera ed, 1991); THE ROAD BEFORE US: 100 GAY POETS (Assoto Saint ed, 1991) (black gay poetry); DARIECK SCOTT, TRATTOR TO THE RACE (1995) (novel with black gay themes); SHADE: AN ANTHOLOGY OF FICTION BY GAY MEN OF AFRICAN DESCENT (Bruce Morrow \& Charles H. Ropiell eds, 1996); SOJOURNER: BLACK GAY VoICES IN THE AGE OF AIDS (B. Michrel Hunter ed, 1993) (poetry); TALKING BLACR: LESBIANS OF AFRICAN AND ASIAN DESCENT SFEAK OUT (Valeric Mrson-John ed, 1995) (anthology); WALTER L. WILLIAss, THE SPIRT AND THE FLESH: SEXUAL DIVERSTT DN AMERICAN INDIAN CULTURE (1986). See also URVASHi VAD, VIRTUAL EQUALTT: THE MaRSTREA3ITIG OF GAY \& LESBLAN LIBERATION (1995) (a critique and historical sketch of gay and lesbian politics, written by an Indian lesbian and former head of the National Gay and Lesbian Task Force, which urges gay rights movement to locate itself within broader movements for social change-including racial, gender and class equality).

10. LORDE, The Transformation of Silence Inlo Longuoge and dcllon, in SISTER OUTSDER, supra note 9, at 44. Audre Lorde died on November 17, 1992 of breast cancer. Audre Lorde, 58, a Poet, Memoirist and Lecturer, Dles, N.Y. TwIEs, Nov. 20, 1992, at A23.

11. See VAD, supra note 9, at 286 ("A false assumption underlies all gay and lesbian organizing: that there is something at once singular and universal that can be called gay or lesbian or bisexual or even transgendered identity.").

12. The body of legal scholarship on the interaction of mee and sexuality remains in its infancy-much of the scholarship published during the completion of this Article-and is not formaliy linked. Also, most of the articles in this area offer only a brief exposition of the 
This Article introduces the concerns of this movement ${ }^{13}$ into legal

issue. For a sampling of literature exploring the subject, see Mary Eaton, Homosexual Unmodlfied: Speculation on Law's Discourse, Race, and the Construction of Sexual Identity thereinafler Homosexual Unmodified], in LEGAL INVERSIONS: LESBIANS, GAY MEN AND THE POLMICS OF LAW 46. 76 (Didi Herman \& Carl Stychin eds., 1995) (arguing that homosexuality is coded as "white" in judicial opinions) [hereinafter Legal INVERsions]; Cynthia Petersen, Envisioning a Lesblan Equality Jurisprudence, in LEGAL INVERSIONS, supra at 118.37 (criticizing omission of race in lesbian legal analysis); Elvia R. Arriola, Fairies, Marimachas, Queens and Lezzies: The Construction of Homosexuality Before the 1969 Stonewall Riots, 5 COLUM. J. GENDER \& L. 33 (1995) (attributing police harassment of gay participants in New York City's Stonewall riots to their race, class, and gender role nonconformance); Elvia R. Arriole, Gendered Ineguality: Lesbians, Gays, and Feminist Legal Theory, 9 BERK. WOMEN's L.J. 103, 132-35 (1994) (discussing omission of race and class in lesbian legal theory) [hereinafter Gendered Inequality]; Mary Eaton, At the Intersection of Gender and Sexual Orientation: Toward Lesblan Jurlsprudence, 3 S. CAL. REV. L. \& WOMEN's STUD. 183, 212-18 (1995) (criticizing omission of race in lesbian legal analysis) [hereinafter $A t$ the Intersection] Angela Gilmore, They're Just Funny That Woy: Lesbians, Gay Men and African-American Communities As Vieved Through the Privacy Prism, 38 How. LJ. 231 (1994) (discussing relationship of black gays and lesbians with the black community); Eric Heinze, Gay and Poor, 38 How. L.J. 433 (1995) (arguing that poor gays and lesbians may have specific needs requiring further sociological and legal analysis); Darren Rosenblum, Queer Intersectionality and the Failure of Recent Lesbian and Gay "Victories," 4 LAW \& SE.UALTYY 83 (1994) (arguing that gay and lesbian litigation "victories" may not uniformly benefit the gay and lesbian community due to race, class, gender, and gender identity differences). The Southern California Review of Law and Women's Studies has also published a series of essays, presented at a symposium, that add to this literature. See Sheila M. Aguilar, Los Angeles Asian Pacific Islander Sisters (LAAPIS), 5 S. CAL. REv. L. \& WOMEN's STUD. 75 (1995) (discussing political and social activities of Asian lesbian organization); Isabelle R. Gunning, Stories from Home: Tales from the Intersection of Race, Gender and Sexual Orlentation, 5 S. CAL. REV. L. \& WOMEN's STUD. 143 (1995) (discussing impact of racism and homophobia on black lesbians); Joan W. Howarth, First and Last Chance: Looking for Lesbians in Fifies Bar Cases, 5 S. CAL. REv. L. \& WOMEN's STUD. 153 (1995) (discussing issues of race, class, and gender status implicated in 1950s California cases challenging state efforts to close gay bars); D. Lisa Powell, Uniled Lesbians of African Herilage, 5 S. CAL. REV. L. \& WOMEN's STUD. 81 (1995) (discussing political and social activities of black lesbjan organization); Ruthann Robson, To Market, To Market: Considering Class in the Context of Lesbian Legal Theorles and Reforms, 5 S. CAL. REV. L. \& WOMEN's STUD. 173 (1995) (discussing impact of class and economic markets upon lesbians); Francisco Valdes, Sex and Race in Queer Legal Culture: Ruminations on Identities and Interconnectivities, 5 S. CAL. REV. L. \& WOMEN'S STUD. 25 (1995) (arguing that sex and race create internal conflicts within "sexual minority communities" and that these communities must, therefore, develop a discourse on the connections between race, gender, and sexuality).

13. This Article is also greatly inspired by a body of critical race, antiracist, and feminist scholarship that explores the relationship between race and gender. See, e.g., ALL THE WOMEN ARE WhITE, All the Blacks ARE MEN, BUT SOME OF US ARE BRAVE (Gloria Hull \& Patricia B. Scott eds., 1982); ANGEla DAvis, WOMEN, RACE \& Class (1981); PaUla GIDDINGS, When aNd WHERE I ENTER: THE IMPACT OF BLACK WOMEN ON RACE AND SEX IN AMERICA (1984); BELL HOOKS, AN'T I A WOMAN? BLACK WOMEN AND FEMINISM (1981) [hereinafter AIN'T I A WOMAN?]; BELL HOOKS, FEMINIST THEORY: FROM MARGIN TO CENIER (1984) [hereinafter FROM MARGN TO CENTER]; BELl HOOKS, YEARNING: RACE, GENDER AND CULTURAL POLMCS (1991); ELIZABETH V. SPELMAN, INESSEN-

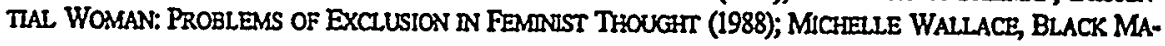


discourse in an attempt to initiate a dialogue around issues of race and class $^{14}$ between those scholars presently engaged in the construction of gay and lesbian legal theories. ${ }^{15}$ Part II examines specific acts of violence and discrimination against gay, or perceived as gay, people of color, and the legal and political challenges to these acts, in order to demonstrate the ready interplay between race, class, and sexual subordination-or the multidimensionality of oppression. Part III contrasts the

CHO AND THE MYTH OF THE SUPERHOMAN (1979); Linda L. Ammons, Afules, Mfadonnas, Bables, Bath Hater, Racial Imageny and Stereotypes: The African-American IFoman and the Battered Foman Syndrome, 1995 Wis. L. REv. 1003; Amii Larkin Bamard, The Appllealion of Crilical Race Feminism to the Anti-Lynching Movement: Black Homen's Fight Against Race and Gender Ideology 1892-1920, 3 UCLA WOMEN's LJ. 1 (1993); Darci E Burrell, Rfyth, Stereothpe, and the Rape of Black Women, 4 UCLA WOMEN's LJ. 87 (1993); Kimberle Crenshaw, Demerginalizing the Intersection of Race and Sex A Black Feminist Criltque of Antidiscrimination Doctrine, Feminist Theory and Antiracist Pollites, 1989 U. Chi. LEGAL F. 139 [hereinafter Demarginalizing the Intersection]; Kimberie Crenshaw, Mopping the Mfargins: Intersectlonalib; Identity Polities, and Violence Against Women of Color, 43 STAN. L. REV. 1241 (1993) thereinafter Mapping the Margins]; Angela P. Harris, Race and Essentialism in Feminist Legal Theon; 42 STAN. L. REV. 581 (1990); Marlee Kline, Race, Racism and Feminist Legal Theon; 12 HARV. Women's L.J. 115 (1989); Maria L. Ontiveros, Three Perspectives on IForkplace Harassment of Fomen of Color, 23 Golden GATE U. L. REv. 817 (1993); Dorolhy E Roberts, Punlshing Drug Addicts tho Have Babies: Women of Color, Equality, and the Right of Privag, 104 HARV. L REV. 1419 (1991); Judy Scales-Trent, Black Homen and the Constitullon: Finding Our Place, Asserting Our Rights, 24 HARV. C.R-C.L. L. REV. 9 (1989); Peggie R. Smith, Separate Identities: Black Women, Work, and Tille VII, 14 HARV. Wostex's LJ. 21 (1991); Debonh J. Krauss, Note, Regulating Women's Bodies: The Ad'erse Effect of Fetal Rights Theory on Chlldbirth Decisions and Women of Color, 26 HARV. C.R-C.L. L. REV. 523 (1991); Calhy Scarborough, Note, Conceptualizing Black Women's Employment Expertences, 98 YaLE LJ. 1457 (1989).

14. Because race and class are interlocking forces, I have included a significant discussion of class inequality and poverty in this "racial" critique of gay and lesbian legal theory and political discourse. This Article, however, does not "extensively" analyze "female" status and patriarchy-although they also inform sexual subordination. Because this Article largely omils patriarchy from analysis, it essentializes, to some degree, the experiences of people of color and is subject to the criticism that it tends to reflect gay male experiences. I do not intend, hoprever, to represent the experiences of all gay people of color. Accordingly, I have explicitly stated, where appropriate, how "maleness," the negative construction of men of color, and female status-rather than the essentialist notion of "race"-have informed my discussion of anti-gay discrimination.

Furthermore, even though this Article attempts to portray incidents in the lives of gay men of color, it cannot fully capture the complexity of their experiences. No single article could complete such a feat. Instead, I hope this Article will serve as a starting point for a more intense examination of the various complexities of gay life. Accordingly, I invite and encourage similar discussions, including feminist critiques of this Articie, surrounding gender, class, race, and other sources of disemporierment.

15. For an excellent compilation of the rapidly growing body of legal scholership pertaining to gay and lesbian issues, see Standing Comm. on Lesbian and Gay Issues, Am. Assoc. Law Libraries, Sexual Orientation and the Law: A Selectrie Blbliogrophy on Homosensally and the Lat: 1969-1993, 86 LAW LIBR. J. 1 (1994). 
multidimensional nature of these gay and lesbian experiences with gay and lesbian legal theory and political discourse, which, by excluding issues of racial and class subordination from analysis, have a narrow and essentialist ${ }^{16}$ focus. In Part III, I argue that gay and lesbian essentialism negates and obscures the experiences of people of color and the poor, centralizes the experiences of race- and class-privileged individuals, renders inadequate the theories and solutions proposed to explain and confront sexual subordination, and fosters tension with antiracist political agendas and with people of color. In Part IV, I locate my racial critique of gay and lesbian legal theory and political discourse within the extensive and ongoing anti-essentialist debates in feminist legal theory and critical race theory. ${ }^{17}$ I also demonstrate how this Article develops and extends these debates. Finally, I invite gay and lesbian legal theorists and political activists to engage in a conversation around sexual, racial, and class inequality and to adopt a "multidimensional framework"- or multidimensionality-to analyze and challenge sexual subordination. By offering multidimensionality to gay and lesbian legal theorists and political activists, I wish to provide them with a methodology by which to analyze the impact of racial and class oppression (and other sources of social inequality) upon sexual subordination and gay and lesbian experience and to cease treating these forces as separable, mutually exclusive, or even conflicting phenomena. In time, gay and lesbian scholars and activists may begin to see the terms "gay," "lesbian," and "homophobia" as multilayered. Furthermore, a multidimensional construction of sexual identity oppression can enrich gay and lesbian legal theory and political action by permitting a deeper analysis of power inequality among gays and lesbians and between gays, lesbians, and heterosexuals. Finally, multidimensionality will allow gay and lesbian legal theorists and political activists to reformulate their theories and activism so that they no longer relegate people

16. In this Article, "essentialism" refers to an attempt to define a group as unitary despile its members' diverse, as opposed to "essential," experiences. See Richard Delgado, Rodrigo's Sixth Chronicle: Intersections, Essences, and the Dilemma of Social Reform, 68 N.Y.U. L. Rev. 639, 674 n.4 (1993); Harris, supra note 13, at 584. The discussion of essentialism in this Article is, therefore, distinct from the essentialism/constructivism debates in gay and lesbian legal theory which discuss whether a "homosexual orientation" is an "essential," "decp-rooted, fixed, and intrinsic feature of individuals" or whether "it is a contingent, socially malleable trait .... Janet E. Halley, Sexual Orientation and the Politics of Biology: A Criltque of the Argument from Immutability, 46 STAN. L. REV. 503, 547 (1994). I do not wish to imply, however, that these debates are necessarily distinct.

17. See supra note 13. 
of color and the poor (and racism and poverty) to "shadows and silence."

For the wages of sin were visible everywhere, in every winestained and urine-splashed hallway, in every clanging ambulance bell, in every scar on the faces of the pimps and their whores, in every helpless, newbom baby being brought into this danger, in every knife and pistol fight on the Avenue, and in every disastrous bulletin: a cousin, mother of six, suddenly gone mad, the children parcelled out here and there; an indestructible aunt rewarded for years of hard labor by a slow, agonizing death in a terrible small room; someone's bright son blown into etemity by his own hand; another turned robber and carried off to jail. ${ }^{18}$

\section{HETEROSEXISM AND HOMOPHOBIA:}

\section{a Combination of Racial, Class, and SeXual Oppression}

In the early morning dawn in Queens, New York, June 2, 1990, three male members of a neo-Nazi, white supremacist gang murdered Julio Rivera-a 29-year-old, gay, Puerto Rican male. ${ }^{19}$ Rivera's killers attacked him repeatedly with a hammer, wrench, beer bottle, and knife. One of the white supremacist assailants later confessed, in connection with a plea agreement, that they killed Rivera "because he was gay."20 Rivera's murder tragically reminded gay and lesbian people of their vulnerability to hate-inspired violence. Rivera's death also presented intersecting issues of racial, class, and sexual marginalization-issues that were largely omitted from political discourse surrounding his death.

Immediately following Rivera's death, gay and lesbian activists monitored and criticized the police investigation. In particular, they objected to the police refusal to classify the murder as an anti-gay crime. $^{21}$ The police refused to characterize the crime as gay-related

18. JAMES BaLDWIN, THE FIRE Next TIME 20 (1963).

19. For a detailed account of the murder, see Alessandra Stanley, The Symbols Sparmed by' a Killing, N.Y. TWES, Nov. 18, 1991, at B1.

20. Joseph P. Fried, A Murder Verdict Becomes a Ralbying Coj, N.Y. TnES, Nov. 24, $1991, \S 4$, at 6.

21. See id. at 6. Under New York law, persons who commit acts of violence on the basis of sexual orientation are not subject to any enhanced or special penalties. See Martin S. Zwerling, Legislating Against Hale in New York Blas Crimes ard the Lesblan and Gay Community, 11 TOURO L. REV. 529, 561 (1995) (ciling Arthur S. Leonasd, Blas Molhated Crime Requires New Law; N.Y. L.J., Sept. 25, 1989, at 2). Rnther, the statule only provides cn- 
despite its extreme brutality and its occurrence in an isolated schoolyard known as a meeting place for gay men. ${ }^{22}$ Instead, the police insisted that the crime was drug-related, noting Rivera's "cocaine habit" and the fact that "drug dealers" also frequented the park. ${ }^{23}$ The police never assigned a full-time investigator to the case. ${ }^{24}$ The police's response to the crime outraged gay and lesbian groups, which proclaimed Rivera's murder "the Gay Howard Beach."25

Although gay and lesbian activists compared Rivera's slaying to the racially motivated Howard Beach incident, the racial and class subordination issues implicated by Rivera's killing and the police response escaped analysis. ${ }^{26}$ The most obvious reason for believing that racism

hanced penalties for acts of violence based on the "race, color, religion, or national origin" of the victim. See 39 N.Y. Penal Law \& 240.30 (McKinney 1996 Supp.). Furthermore, "the current penalty scheme does not cover [any] acts motivated by the defendant's prejudico which result in the death of the victim." Zwerling, supra, at 562. Nevertheless, classification of Rivera's murder (and other acts of anti-gay violence) as "gay-related," could have bolstered political efforts to make "sexual orientation" a protected status under New York penal law.

22. See Fried, supra note 20, at 6 . In his groundbreaking study of homophobic violence, Gary David Comstock notes that such violence often involves torture, mutilation, and excessive physical assault, and that many of these crimes against gay men occur in gay cruising areas by groups of perpetrators. GARY DAVID COMSTOCK, VIOLENCE AGAINST LESBLANS AND GAY MEN 46-51, 66 (1991).

23. See Fried, supra note 20 , at 6.

24. See Donna Minkowitz, It's Still Open Season on Gays: Prosecution of Gay Bashers, 254 THE NATION 368 (1992).

25. See Joseph P. Fried, Trial in Gay Man's Killing Opens in Court in Queens, N.Y. ThMES, Nov. 7, 1991, at B3. Gay and lesbian activists compared Rivera's slaying to the racially motivated attack of three black men by a group of whites in Howard Beach, Queens, on December 20, 1986. The gang of whites beat the black men with bats and sticks and then chased them into a road where one of the black men was struck by a car and killed. Police characterized the attack as a bias crime. One of the survivors reported that the gang shouled "niggers, you don't belong here," as they attacked the men. See Robert D. McFadden, Black Man Dies After Beating by Whiles in Queens, N.Y. TMMES, Dec. 21, 1986, §1, at 1 .

26. See infra pp. 584-85, 626-34 (discussing how use of sex-race analogies by gay and lesbian political activists preclude discussions of race). Although gay and lesbian activists responded to Rivera's murder with needed vigor, they explained his victimization and the police responses largely as manifestations of homophobia. See, e.g., sources cited supra notes 19-21, 24-25. See also THE QUESTION OF EQUALITY (1995) (documentary on gay civil rights movement); Robert Vazquez-Pacheco, In Their OHn Words, in THE QUESTION OF EQUALITY 124 (David Deitcher ed., 1995) (companion book to documentary) ("No one wanted to discuss race in relation to the Rivera case, even though race was one of the most blatant things about it."). But see Gays Seek Justice for Victim of Hate, ORLANDO SENTINEl TRIB,, Dec. 1 1991, at A13 (reporting activist's belief that the police "branded Julio as a Latino, dojg user, hustler and therefore not worthy of anything . . . .) (quoting Matt Foreman, head of the New York City Gay and Lesbian Anti-Violence Project); Vazquez-Pacheco, supra, at 124 (noting racial activism of Latino gay men in the aftermath of Rivera's death). Consequently, issues of race and class which led to his murder and shaped the police response remained unexamined and unchal- 
may have contributed to Rivera's slaying is the fact that he was killed by members of a white supremacist organization. Although one of the assailants testified that the group killed Rivera because he was gay, Rivera's Latino status likely rendered him particularly vulnerable to the homophobic attack. ${ }^{27}$ Viewed in this manner, Rivera's assault can be characterized as an act of "racist-homophobia," rather than a "gay" bashing.

Newspaper articles reporting the murder, and the public and police responses to it, vividly highlight racial and class aspects of the crime. Several articles emphasize that Rivera was a Puerto Rican man with a cocaine addiction who grew up "in a South Bronx project"28 - a combination resulting in the archetype of urban violence. They also report that Rivera was "very Latin [and] very macho."20 Thus, as one article reports, "Rivera ... was the most improbable gay martyr-a Hispanic drug user from Queens who lived on the far fringes of gay society. These articles use racial and heterosexist stereotypes of men of color to construct a portrait of Rivera as a "hot, macho, Latin"31 - a man whose

lenged.

27. See Julie Inness, Going to the Bottom, 9 BERK. WOMEN'S LJ. 162, 170 (1994) ("When a Black lesbian is called a 'dyke,' the rord cannot be understood as directed at her only as a lesbian; her attacker wishes to harm her because he sees her as a Black lesbian . . . ."). Members of the skinhead group denied charges of racism, see Peg Tyre, Formar "Stinhizads" Deny Racism, NEwsday, Nov. 14, 1991, at 19, as well as homophobia, see Curtis L. Taylor, Accused Killer: I'm Not Homophobic, NewsDay, Nov. 8, 1991, at 21. Given the conlext in which they were made-the wake of a criminal trial-these statements were likely selfeserving, offered only to garner public support for the assailants and, thus, devold of any credibility.

28. Stanley, supra note 19, at Bl. The "South Bronx" refers to a largely poor and Puerto Rican neighbornood in the Bromx, New York.

29. Id. See also Donatella Lorch, An Unllkely Marthr Focuses Ga' Anger, N.Y. TnuEs, Nov. 15, 1991, at B1 (reporting that Rivera "loved to "play mecho"').

30. Stanley, supra note 19 at $\mathrm{Bl}$.

31. Jenny Rivera comments that

[h]istorically, Latinos have been stereotyped as violent and allen. This misrepresentition of the "Latino character" has developed during the past century, and non-Latino society today continues to express and exploit ineccurate images of Latinos and Latino family life.

Popular myth has become accepted as truth; Latino males are believed to be irrational and reactive. The standard description of Latino males as hot-blooded, passionate, and prone to emotional outbursts is legendary. Wocho' is the accepted -and expected-single-word description smomyous with Lalino men and male culture. Consequenty, it is natural to expand and apply this construct to the entire Latino community, and thereby justify the assumptions that Latinos are violent.

Jenny Rivera, Domestic Fiolence Against Latinas by Latino Males: An Arabysis of Race, National Origin, and Gender Differentials, 14 B.C. THIRD WORLD LJ. 231, 240 (1994) (discussing racial stereotyping of Latino males) (citations omitted) (emphasis added). 
status as a symbol of sexual subordination was, therefore, deemed "unlikely" and "improbable."32

While the subtext of race and class clearly impacted the reporting of Rivera's murder, the conclusion that racial and class biases may have also influenced the police reaction can be inferred from the circumstances of the crime, the nature of the police response, and the greater social context of racial, class, and sexual subordination. There are at least two possible explanations for the police department's initial failure to classify the crime as an anti-gay murder. Each involves a combination of racial, class, and sexual oppression issues. First, the police may not have actually believed Rivera was gay. Second, the police may have known or discovered Rivera was gay but, despite the compelling evidence of anti-gay motive, decided against labelling the crime a gay bashing. ${ }^{33}$

Under the first explanation, the police did not believe Rivera was gay. Such disbelief possibly resulted from competing stereotypical images which construct "gay" men as effeminate and weak" and poor "Latin" men as "macho" and violent ${ }^{35}$ - thus heterosexual. ${ }^{36}$ These negative class, racial, gender, and sexual constructs may have made it difficult-or impossible-for the officers to comprehend that Rivera was actually "gay" and the victim of anti-gay violence. ${ }^{37}$ Under these competing stereotypes, a "Latino gay man" becomes an oxymoron. Hence, as one newspaper reports, Rivera's victimization "do[es] not hold up to . . . perfunctory logic."38 Under racial and class hierarchy,

32. Lorch, supra note 29 , at $\mathrm{B1}$.

33. These explanations are not necessarily exclusive of each other; that is, both may explain the police response.

34. See RICHARd A. ISAY, BEng HoMOSEXUAL: GAY MEN AND THEIR DEVELOPMENT 20 (1989); A.P. MacDonald, Jr., Homophobia: Its Roots and Meanings, 3 HomosexuAl CoUNSEING J. 23, 30 (1976).

35. See Rivera, supra note 31 , at 240.

36. The clash between Rivera's "Latino" and "gay" statuses reveals that "gay" stereotypes are culturally, racially and class contingent. See infra pp. $609-13$ (discussing multilayered nature of gay and lesbian stereotypes).

37. Under racial hierarchy, Rivera could possibly not be a "victim" at all, but rather a threat and a criminal. For a more extensive discussion of this point, see generally Stephen L. Carter, When Victions Happen to Be Black, 97 YALE LJ. 420, 421 (1988), which argues that the "meaning of victimhood in our society is constructed by a dominant culture that often displays difficulty conceiving that important hams can come in varieties unlikely to afflict its members."

38. Stanley, supra note 19 , at B1. This article suggests that the status of Rivera as a "victim" and Daniel Doyle, one of his assailants, as a killer, is ironic because "[i]t was Mr. Rivera, a longtime cocaine user, whom close friends describe as deeply troubled and unhappy," $i d$, while Mr. Doyle had a 3.4 grade point average and was "very smart, very sweet, very 
however, one has less difficulty visualizing a poor, heterosexual, "macho," Latino drug addict killed in an illegal narcotics transaction.

The second explanation assumes that the police actually knew Rivera was gay-either after their own investigation or the activists' forceful protests-but declined to classify the crime as a "gay" bashing, despite evidence of anti-gay motive. Racial, class, and sexual bias again may have informed the police inaction. Homophobic police would not want to draw greater public attention to the problems of homophobic violence by truthfully labelling the crime as an act of antigay bias. ${ }^{39}$ The police, if they were homophobic, needed an alternative interpretation of the crime- one that diminished or erased the significance of Rivera's sexuality. Rivera's race and class provided this necessary diversion and helped the police reconstruct the facts of Rivera's murder and negate his homosexuality. The police invoked the classand race-based images of poor Latinos as "criminals" and "drug-users" to detract from Rivera's victimization and to recast him as responsible for his own murder. The police then manipulated these racial and class constructs to suppress the homophobic nature of the crime and to excuse their own inaction. Consequently, racism served to reinforce homophobia.

The activists' essentialist framing of the crime as a "gay" bashing, rather than a racist-homophobic attack, may actually have invited the police to use Rivera's race to erase his gayness. Had the activists stressed both the homophobic and racial motivations of the skinhead assailants and portrayed Rivera as a gay. Latino victim, the police's racially-coded explanation would have backfired: it would have buttressed a claim that racial bias contributed to Rivera's death and to their own indifference to his attack. A multidimensional response, by contrast, exposes and confronts the negative class, racial, and heterosexist forces that may have informed the police inaction. Under a multidimensional framework, the police's race- and class-based explanation would have failed or been problematic from the outset. ${ }^{10}$

The race and class issues implicated by Rivera's death demonstrate

committed to his work," id. (quoting Doyle's college English professor).

39. The activists' focus on homophobia suggests that they believe this reason explains the police response.

40. I do not wish to imply that a multidimensional response would have prevented the offcers' manipulation of race and class. Given the irrationality of racism, such a response may have occurred even under multidimensional activism. Rather, I believe that multidimensionality would have provided a more accurate and possibly more effective political response to the officers' inaction. 
the importance of considering multiple sources of disempowerment when responding legally and politically to sexual subordination." Rivera, however, suffered a violent combination of class, racial, and sexual subordination during his life as well. Placing Rivera's death in the context of his life, instead of viewing him solely at the moment he was killed, permits a better understanding of the interplay between racial, class, and sexual subordination. Rivera, like scores of Puerto Ricans in New York City, was poor, ${ }^{42}$ unemployed, ${ }^{43}$ uneducated (formally), ${ }^{44}$ and gay. During his short life, Rivera attempted to "deal" with these statuses. In order to escape poverty-and "the far fringes of gay society"-an adolescent Rivera entered into a series of relationships with "wealthy, older men who introduced him to the theater, fine food and wine, designer clothes, cocaine and the club scene."\$5 Soon Rivera grew to "like[ the best of everything . . . and he got it from the men in his life; Armani suits, crystal, the best colognes. Once he saw the good side of life, he could never go back to where he came from"- the South Bronx. ${ }^{46}$ Rivera, however, "was never a really happy person [due to the homophobia of] his uncles and aunts . . . [and] the stigma of being from the South Bronx."47 Instead, Rivera developed self-destructive habits, eventually succumbing to a cocaine addiction and apparently sustaining this addiction by exchanging sex for "money or drugs" in risky, anonymous encounters. ${ }^{48}$ Rivera's self-destructive be-

-41. Under a multidimensional paradigm, for example, gay and lesbian legal theorists and civil rights attomeys might challenge police inaction to violence against gays and lesbians by filing claims of racial discrimination. See infra pp. 578-81 (discussing racial discrimination suit brought to remedy police inaction in wake of a physical assault on person of color whom police perceived as "gay").

42. A sampling of social statistics with respect to the Latino community shows that Rivera's plight was all too common. In 1990, $25 \%$ of Latino families lived below the poverty level, compared to $9.5 \%$ of non-Latinos. See U.S. Dep't of Commerce, Econ. and Stat. Admin., Bureau of the Census, The Hispanic Population in the Uniled States 8 (Current Population Reports Population Characteristics Series P-20, No. 455, Mar. 1990). Also, Latino children accounted for $21 \%$ of children living in poverty although they represented only $11 \%$ of the total population of children. See id. Among Latinos, Puerto Rican families had the highest rate of poverty-37.5\%.

43. In 1990 the Latino unemployment rate was $10 \%$ compared to $6.9 \%$ for non-Latinos. See id. at 3.

44. In 1991 only $51 \%$ of Latinos had completed at least four years of high school. Only $10 \%$ had completed four years of college. See id.

45. Stanley, supra note 19, at B1.

46. Id. (quoting Rivera's sister).

47. Id.

48. Curtis L. Taylor, Witness Recounts Gay Man's Death, NEwSDAY, Nov. 7, 1991, at 8 (the assailants "us[ed] money or diugs for sex to lure Rivera into a hidden alcove in the school- 
haviors, possibly spawned by the oppression he faced, ${ }^{49}$ helped to create the circumstances surrounding his death. ${ }^{50}$ Rivera never overcame the combination of homophobia, racism, and poverty in his life, and he died without "ever lik[ing] himself."

Thus, a "re-reading" of Rivera's life reveals that the debilitating forces of racial, class, and sexual subordination worked violence against him long before his death. These forces limited his life choices, contributed to his murder, and explain the ambivalent police response to the crime. ${ }^{52}$

Another tragedy of racial, class, and sexual subordination is presented by the life and death of Venus Xtravaganza, a young, poor, Puerto Rican, transsexual male featured in the film Paris Is Burning, ${ }^{53}$ a documentary on poor, gay and transgendered blacks and Latinos who live in New York City. Paris Is Burning examines Harlem's "drag ball" culture, which has its roots in the Harlem Renaissance." Venus, a partici-

yard").

49. Several studies have linked alcohol and substance abuse to stress associated with sexual subordination. See Dennis Anderson, Fanily and Peer Relatlons of Goy Adoleseents, 14 ADOLESCENT PSYCHIATRY: DEV. AND CLINICAL STUD. 162, 176 (1987); Robert J. Kus, Alcokollsm and Non-dcceptance of Goy Self: The Crilical Link, 15 J. HoslosexualmY 25, $25-26$ (1988); David J. McKirnan \& Peggy Peterson, Stress, Expectancies, and Vulnerability to Substance Abuse: A Test of a Model Among Homosexual Men, 97 J. ABNorMel PsYcrol 461, 465 (1988); Rosurio, Hunter \& Rotheram-Borus, HIV Center for Clinical and Behavioral Studies, New York State Psychiatric Institute, Unpublished Data on Lesbian Adolescents (1992).

50. See Taylor, supra note 48 , at 8.

51. Stanley, supra note 19, at BI (quoting Rivera's sister).

52. Two of Rivera's assailants were convicted by a jury of second-degree murder. The third, who testified against the other trio, pleaded guilty to manslaughter. Joseph P. Fried, 2 Accomplices Guilty of Murder in "Gay Bashing" Case in Queers, N.Y. TMEs, Nov. 21, 1991, at A1. During the trial, the judge sparked a controversy by privately questioning prospective jurors regarding their sexual orientation and their attitudes toward gays and Iesbians. Joseph P. Fried, Judge in Queens Murder Trial Admils Asking Juror Whelther She Is Homosexual, N.Y. TaMes, Nov. 5, 1991, at BI. The judge did not permit defense counsel or prosecutors to attend the questioning. Id. An appellate court subsequently reversed the convictions, finding that the private questioning denied defendants their right to a "public trial" under the Sixth and Fourteenth Amendments of the United States Constitution. See New York Y. Bici, 621 N.Y.S.2d 666 (App. Div. 1995); New York v. Brown, 621 N.Y.S.2d 668 (App. Div. 1995). Brown, one of the defendants whose conviction was overtumed, subsequently pleaded guilty to a reduced charge of first-degree manslaughter and agreed to testify for the prosecution in the re-trial of the remaining co-defendant. See Joseph P. Fried, Man Gullh' in '90 kJlling in Queens, N.Y. Thes, May 14, 1996, at B3. Bici, the remaining co-defendant, friled to appear for a court hearing after his accomplice agreed to cooperate with authorities. Defendant in Xilling Fails to Appear, N.Y. Tares, May 15, 1996, at B6. A judge subsequently revoked Bici's bail and ordered his arrest. See id Bici, however, remains missing. See Scoth Fallon, Gay Activists Blast Sigj-Case Release, NewSDAY, June 23, 1996, at A29.

53. Paris Is BurNING (Prestige Films 1991).

54. See Her.phII, To Be Real, in Cerearonies, supra note 9, at 119 (citing Eric Garber, A 
pant in the balls, wants to taste "power," which life has taught her is clustered around whiteness, wealth, and heterosexuality. To this end, she desires to become "a spoiled, rich white girl [because t] hey get what they want whenever they want it ... a and they don't have to really struggle with finances."5s Other individuals in the film share Venus' desires. Participants in the drag balls competitively "mock[] and play[ out the rituals of a fashion show." the "high" fashion world they mimic,

power remains almost exclusively defined in materialistic, Caucasian, and consumer terms. Many long to be rich and famous. Some long to be white and female, clearly an escapist longing, a longing that if realized would then place them in collusion with white supremacy-the primary source of their present disempowerment. They want to be stars in a world that barely wants to see them alive and thriving. They want things in a world that has caused more than a few of them to not want themselves. ${ }^{57}$

The fantasy of drag ball culture, however, cannot negate the reality

Spectacle in Color: The Lesbian and Gay Subculture of Jazz Age Harlem, in HIDDEN From HistoRY: RECLAIMING THE GAY AND LesBiAN PAST (Duberman, Vicinus \& Chauncey cds., 1990). All references in this Article to Paris Is Buming are taken from Ceremonies in which Hemphill discusses the film at length. See id. at 111-21. Hemphill, a black gay poet, died on November 4, 1995, due to complications from AIDS. Essex Hemphill, 38, Poet and Performer, N.Y. TIMES, Nov. 10, 1995, at B7.

55. HEMPHIL, supra note 54 , at 118.

56. Id. at 111 .

57. Id. at 116. See also BELl HOOKS, Is Paris Burning?, in BLACK LOOKS: RACE AND REPRESENTATION 147-48 (1992) ("What viewers [of Paris Is Burning] witness is not black men longing to impersonate or even to become like "real" black women but their obsession with an ldealized, fetishized vision of femininity that is white."). Hemphill draws a parallel between the oppression-induced fantasy of drag ball culture and similar manifestations in rap music. He argues that

[i]t would be inaccurate to suggest that using illusion to construct identity is unique to Black gay reality. Everyone is capable of creating and employing illusion and fantasy for whatever purpose. An immediate example can be cited in a style of rap music known as "gangsta rap." The rapper boasts of being an oullaw, of having control and power, guns and money; again, things longed for by the disempowcred . ... They are seductive longings, mutated dreams forged from the multitudinous oppressions constructing American society.

HEMPHLL, supra note 54, at 116. Although I agree with Hemphill's observation that rap music often expresses a longing for masculinist power, I disagree with his implicit, though possibly unintended, assumption that rap culture is external to "Black gay reality." For a fictional, "popular culture" account of the relationship between "hip-hop" and black gay and bisexual culture, see JAMES EARL HARDY, B-BOY BLUES (1994). 
of multilayered subordination-but can only "temper" and "obscure" it. $^{58}$ Thus, Venus never realizes her escapist longings. Instead, she begins to engage in sex work to survive: "she always took a chance. She always went into a stranger's car. She always did what she wanted to get what she wanted .... ."s9 Later, Venus, as a friend recounts, is murdered, and police discover "her dead after four days, strangled, under a bed in a sleazy hotel in New York City . . . . But that's part of life; that's part of being a transsexual in New York City and surviving.'\$0 Venus' disempowerment was caused by an active interplay of poverty, racism, and sexual subordination, and her life and death may not be understood without considering these multiple sources of oppression. ${ }^{6 !}$

One final illustration of the multidimensional nature of oppression is provided by the case of Jeffrey Dahmer. In July 1991 Dahmer, a young white male, confessed to police that he had killed and dismembered seventeen males in his Milwaukee apartment. ${ }^{62}$ Most of

58. HEMPHILL, supra note 54, at 116. The balls, however, do not only temper oppression through fantasy. Rather, they may offer concrete support as participants, organized as teams (or "houses"), sometimes "function as surogate families for Black and Puerto Rican gay youth who may be homeless, orphaned, or rejected by their [biological] families because of their gayness." Id. at 119.

59. Id. at 118 (quoting friend of Venus).

60. Id. (quoting friend of Venus) (emphasis added).

61. The murder of Moses Preston Waller, a black, transgendered sex piorker, also illustrates the intersection of race, class, and sexuality in acts of violence against transgendered, lesbian, and gay people, particularly, the vulnerability of transgendered sex workers to ects of violence. Waller, nicknamed "Silver," was robbed and stabbed in the chest by a prospective client. Andrew Jacobs, No Burial Aid Jor Moses Preston Waller, N.Y. Thus, June 2, 1996, § 13, at 6.

The New York State Crime Victims Board denied a request by Silver's grandmother, Rosalie Roots, for reimbursement of Silver's burial expenses. See id. The bourd denied her request on the grounds that Silver "contributed to the infliction of his injury." Id. A board attomey, however, stated that "it was not common practice for members to reject claims for victims who had engaged in prostitution." Id. (quoting Everett A. Mayhew). Furthermore, Roots claims that a board spokesperson informed her that the board has previously reimbursed families of white heterosexual female prostitutes. See id.

The New York Gay and Lesbian Anti-Violence Project has filed an appenl on Roots' behalf. Id. Windy Brown, the attomey representing Roots, recognizes the meial and sexul aspects of the board's ruling. Brown asks: "Why is a straight white prostitute any more innocent than an African-American prostitute?" See id. The board's decision adds further support for my thesis that discrimination on the basis of sexual orientation is linked wilh rasism and class oppression.

62. See Sinthasomphone v. Milwaukee, 838 F. Supp. 1320, 1321-22 (ED. Wis. 1993). On November 28, 1994, while serving fifteen consecutive life sentences for the murders, Dahmer was beaten to death by a fellow inmate. See Don Terry, Jeffey Dahmer, Mfultiple Killer, Is Bludgeoned to Death in Prison, N.Y. ThIES, Nov. 29, 1994, at Al. 
Dahmer's victims were black gay men. ${ }^{63}$ Dahmer lived in an economically depressed neighborhood. ${ }^{64}$ Like Rivera and Venus Xtravaganza, many of Dahmer's victims were lured to their deaths by promises of money for sexual favors, namely, posing nude for photographs. ${ }^{65}$

Dahmer's confession stunned the nation. Perhaps more surprising than the murders, however, was the revelation that three white police officers had once (prior to Dahmer's confession) responded to emergency calls by Dahmer's neighbors-two black women-and found fourteen year-old Konerak Sinthasomphone, a Laotian youth, drugged, naked, bleeding, and fleeing Dahmer's apartment. ${ }^{66}$ Despite the imperiled condition in which they found Konerak, two of the officers returned him to the apartment after Dahmer convinced them that he and Konerak were "lovers involved in a spat."57 When the officers returned to the police station, they described the case as a "boy-boy" incident and joked that they needed "de-lousing." The officers also failed to enter Dahmer's name into police computers or file an official report of the incident. ${ }^{69}$ Dahmer killed Konerak after the police left. ${ }^{70}$ Subsequent to Dahmer's confession, it was revealed that he had previously been convicted of molesting an older brother of Konerak in 1988. ${ }^{71}$

63. See Edward Walsh, Swreping Changes Urged in Mlwaukee Police Department: Civilian's Report Prompted by Dahmer Case, WASH. POST, Oct. 16, 1991, at A3. Eleven of Dahmer's victims were black. Sinthasomphone, 838 F. Supp. at 1321. I found no sources that verify the exact number of gay men among Dahmer's victims.

64. See Don Terry, Milwaukee Grasping for Answers As Horror Mounts Over Killings, N.Y. TIMES, July 29, 1991, at A1.

65. See William Booth, Dahmer Charged in 8 More Murders, WASH. Post, Aug. 7, 1991, at A1. I have not located any helpful sociological or criminological analysis on the relationship between class, race, sexuality, gay male sex work, and anti-gay violence. The discussion in this Article, however, suggests that this relationship warrants examination.

66. See James Barron, Milswakee Police Once Queried Suspect, N.Y. TIMES, July 21, 1991, $\S 1$, at 6 . Dahmer met Konerak at a Milwaukee mall and enticed the child to accompany him to his apartment with promises of money in exchange for his posing nude or semi-nude for photos. See Sinthasomphone, 838 F. Supp. at 1322. Dahmer testified that he had "drilled a hole" in Konerak's head and drugged him with hydrochloric acid before the youth attempled to escape. Id.

67. Debbie Howlett, Police Were in Dahmer's Room, USA TODAY, Aug. 2, 1991, at 3A.

68. Id.

69. See Barron, supra note $66, \S 1$, at 6 . The officers were suspended for failing to execute these procedures. See $i d$. The two officers who retumed Konerak to Dahmer's apartment were subsequently fired but won reinstatement after a judge found the dismissals "shocking to one's sense of faimess." Victory for Two in Dahmer Case, N.Y. TMMES, Apr. 28, 1994, at B10 (quoting Judge Robert Parins).

70. See Barron, supra note $66, \S 1$, at 6 .

71. See William Celis III, Family Sought New Life Only to Find New Pain, N.Y. TMMES, July 31, 1991, at Al4. Dahmer received an eight-year prison term for this crime, but he was 
Had the police officers conducted a computer search of Dahmer's name, they would have discovered his prior molestation conviction. ${ }^{2}$ The police inaction implicates a combination of racial, class, gender, and sexual subordination issues.

The police officers dismissed the concerns of the two poor black women who reported their fear that a "child [was] being raped and molested by [Dahmer]. ${ }^{373}$ Instead, one officer tried to assure the women that "it wasn't a child, it was an adult . . . I can't do anything about somebody's sexual preferences in life." ${ }^{374}$ An officer also threatened to arrest one of the black women if she persisted in seeking help for Konerak. ${ }^{75}$ Finally, the officers turned away an ambulance crew that arrived on the scene-although one of the paramedics concluded that Konerak needed medical treatment. ${ }^{76}$

Thus, the police ignored Konerak's obvious injuries, denied him necessary medical care, portrayed the incident pejoratively, dismissed the black women, and accepted Dahmer's characterization of the horrible scene they discovered as a lovers' quarrel. Furthermore, the officers apparently believed that violence, drugs, and dramatic differences in age are common features of "boy-boy" relationships-a patently homophobic conclusion. ${ }^{77}$ The officers may have also acted on racist stereotypes of Asian men as effeminate-thus "homosexual"78 - when they "read" the scene as a domestic dispute.

In response to the officers' egregious conduct, Konerak's estate and several of his family members have filed a lawsuit against the officers and the City of Milwaukee under Title 42 U.S.C. Section 1983 ("Sec-

released and placed on probation after serving one year of the sentence. See id.

72. See Barron, supra note $66, \S 1$, at 6 .

73. See Howlett, supra note 67 , at $3 A$ (quoting police transcript).

74. Id. (quoting police transcript) (emphasis added).

75. Sinthasomphone, 838 F. Supp. 1324. Historically, black romen have been pereeived as Iacking credibility as witnesses in legal proceedings due to intersecting reial and gender stereotypes, particularly when they allege that they have suffered sexual assault or harassment. Kimberlé Crenshaw, Race, Gender, and Sexual Harasment, S. CAL. L. REv. 1467, 1470 (1992). In this case, however, they lacked credibility as witnesses of a third-paryy's sexual assault.

76. See Sinthosomphone, 838 F. Supp. at 1324.

77. Neither Dahmer's nor Konerak's sexual orientation is publicly known. In any event, this information is irrelevant for my analysis. The relevant facts in this scenario ase the officers' belief and Dahmer's declaration that he and Konerak were lovers (read "gay") and the officers" anti-gay and racial bias.

78. See Petersen, supra note 12 , at 122 (discussing "racist iconogrophy of manhood" that "typically depicts Asian men as effeminate and passive"); David Mur, How Amertea Unsexes the Astan Male, N.Y. TMMES, Aug. 22, 1996, at C9 (discussing sexual stereotyping of Asian men). 
tion 1983"). ${ }^{79}$ The complaint alleges that the officers' failure to provide protection for Konerak resulted from discrimination on the basis of race and sexual orientation in violation of the Equal Protection Clause of the Fourteenth Amendment of the United States Constitution. ${ }^{80}$ The complaint also alleges that the City of Milwaukee maintained a policy or custom of discrimination against people of color and sexual minorities, pursuant to which the officers acted. ${ }^{81}$ Thus, this litigation is one

79. This statute provides, in relevant part, that

[e]very person who, under color of any statute, ordinance, regulation, custom, or usage, of any State or Territory or the District of Columbia, subjects, or causes to be subjected, any citizen of the United States or other person within the jurisdiction thereof to the deprivation of any rights, privileges, or immunities secured by the Constitution and laws, shall be liable to the party injured in an action at law, suit in equity, or other proper proceeding for redress.

42 U.S.C. \& 1983 (1994). The term "person" used in the statute includes "municipalities" and other local government units. See Monell v. Department of Soc. Serys. of City of Ncw York, 436 U.S. $658,690^{\circ}(1978)$.

80. Although the published decisions in this case do not make clear, through conversations with plaintiffs' attomey, I discovered, as the facts of the case suggest, that plaintiffs' race claim is based on discrimination against Konerak and the two black women and the sexual orientation claim is based on Konerak's perceived sexual orientation.

Police officers generally have no affirmative duty to provide protection. See DeShancy v. Winnebago County Dep't. of Soc. Servs., 489 U.S. 189, 197 (1989). If they discriminate in providing such protection, they may nevertheless violate the Equal Protection Clause of the Fourteenth Amendment, see id. at 197 n.3 (citing Yick Wo v. Hopkins, 118 U.S. 356 (1886)); Freeman v. Ferguson, 911 F.2d 52, 55 (8th Cir. 1990) (citation omitted); Watson v. Kansas City, 857 F.2d 690, 694 (10th Cir. 1988) (citation omitted).

81. See Sinthasomphone v. Milwaukee, 785 F. Supp. 1343, 1347 (E.D. Wis. 1993) (complaint alleges that City of Milwaukee "has a longstanding practice of intentional discrimination against and reckless disregard of the rights of racial minorities and homosexuals."). In order to prevail on a claim of discrimination against a municipality under Section 1983, a plaintiff must demonstrate that the constitutional deprivation was made pursuant to an official municipal policy or custom. See Monell, 436 U.S. at 690-91.

The complaint also alleges that the officers violated Konerak's rights under the Due Process Clause of the Fourteenth Amendment by failing to protect him. See Sinthasomphone 838 F. Supp. at 1328 . The court, however, relying upon DeShaney, held that the officers were entilled to "qualified immunity" and granted them summary judgment on plaintiffs" due process claim. See Sinthasomphone, 838 F. Supp. at 1327-28. The qualified immunity defense shiclds state officials from liability unless the officials' conduct violates "clearly established statutory or constitutional rights of which a reasonable person would have known." Harlow v. Fitzgerald, 457 U.S. 800, 818 (1982). Shockingly, the court attached semi-nude photos of Konerak, taken by Dahmer, to its opinion granting summary judgment, and West Publishing Co. reprinted them in the Federal Supplement. The police officers submitted the photographs into evidence to support their claim that they believed Dahmer and Konerak were lovers. Sin/hasomphone, 838 F. Supp. at 1323. The court based its finding of qualified immunity on its conclusion that "one does not inevitably know that getting a naked person off the streets, taking him to an apartment where his clothes and near-naked pictures of him are present, and leaving him there with a person who convincingly presents himself as a friend will result in death and dismem- 
of the few reported discrimination cases brought by actual or perceived as gay or lesbian people of color, in which the racially and sexually subordinate statuses of the plaintiff is mentioned in the opinion. ${ }^{82}$ It is also the only reported case in which the court found as "factually viable" a multidimensional claim of sexual and racial discrimination. Therefore, although the case overall lacks controversy ${ }^{83}$ and any particularly groundbreaking judicial analysis, it nevertheless merits some attention in this Article.

After conducting discovery, the officers and the City of Milwaukee moved for summary judgment, but the court denied both of these motions. In the affidavits accompanying their motion, the officers disputed that they acted with discriminatory intent ${ }^{84}$ The court, however, held that the undisputed facts would permit a jury to infer that they acted with discriminatory intent. ${ }^{85}$ Discriminatory intent may be shown with direct or indirect evidence. ${ }^{86}$ In this case, the officers' intent, as in most discrimination cases, is subject to proof by circumstantial evidence. ${ }^{87}$ Because plaintiffs' discrimination claim requires proof of the officers' intent or motive through inferences from the surrounding-and compelling-evidence of bias, the claim does not lend itself to summary judgment. ${ }^{88}$ Thus, the court appropriately denied the officers' mo-

berment" Id. at 1328 . The court's decision to attach the photographs to its opinion and West's decision to reprint them further marginalized Konerake.

82. See, e.g., Williamson v. A.G. Edwards \& Sons, Inc, 876 F.2d 69 (8th Cir. 1989) (affirming award of summary judgment to defendant in Title VIl and Section 1981 meial discrimination suit, brought by black gay male plaintiff, on the grounds that plaintiff's allegations related to "homosexuality" a status not protecled by Title VII or Section 1981, rather than race); Watkins v. United States, 837 F2d 1428 (9th Cir. 1988), amended, 847 F.2d 1329, different results reached on reh'g, 875 F.2d 699 (9th Cir. 1989) (en banc), cert. denled, 498 U.S. 957 (1990) (finding military estopped from discharging black gay plaintiff on the basis of his admitted gay status); Rhyne v. Perry, 1995 WL 77970 (S.D.N.Y. Feb. 24, 1995) (dismissing, for failure to exhaust administrative remedies, Tille VI complaint alleging discrimination due to plaintiff's status as a "black male homosexual"). For a criticism of the courts' essentialist treatment of race and sexual orientation in the Hilliamson and Ifatkins cases, see Eaton, Homosexual Unmodified, supra note 12.

83. But see supra note 81 (arguing that the court further marginalized Konerak).

84. See Sinthasomphone v. Milwaukec, 878 F. Supp. 147, 151 (ED. Wis. 1995). In order to prevail on their equal protection claim against the police, the Sinthusomphone estate and family must demonstrate that the officers acted with "discriminatory intent" See Village of Arlington Heights v. Metropolitan Hous. Dev. Corp., 429 U.S. 252, 256 (1977); Washington v. Davis, 426 U.S. 229, 241-42 (1976).

85. See Sinthasomphone, 878 F. Supp. at 151.

86. See Batson v. Kentucky, 476 U.S. 79, 93 (1985); Village of Arlington Helghts, 429 U.S. at 266.

87. See Sinthasomphone, 878 F. Supp. at 151.

88. See id. (citation omitted). See also National Union Fire Ins. Co. v. Turtur, 892 F2d 
tion.

The City of Milwaukee moved for summary judgment on the grounds that in 1991-the same year Konerak was murdered-it allegedly implemented official measures to correct any problems of bias within its police department. ${ }^{89}$ The City of Milwaukee thus argued that the only relevant evidence for determining whether it has a policy of discrimination was its conduct subsequent to 1991 and that this evidence demonstrated that no such policy existed. ${ }^{90}$ The court rejected this argument and held that the police department's pre-1991 history of discrimination was relevant for determining whether the City of Milwaukee had an unwritten "policy" of discrimination against people of color and gays and lesbians at the time of Konerak's death. ${ }^{11}$ The court's ruling is consistent with legal precedent. As the Supreme Court has held, a custom or policy of discrimination may arise in the Section 1983 context when "practices of state officials could well be so permanent and well settled as to constitute a 'custom or usage' with the force of law.",22 Thus, evidence of the department's pre-1991 history is necessary for the trier of fact to determine whether the police department had been engaging in a pattern of discriminatory practices at the time the officers returned Konerak to Dahmer's apartment and whether these practices were "so permanent and well settled" so as to carry "the force of law. 993

199, 205 (2d Cir. 1989) (citing Wechsler v. Steinberg, 733 F.2d 1054, 1058-59 (2d Cir. 1984)); Suydam v. Reed Stenhouse, Inc., 820 F.2d 1506, 1509 (9th Cir. 1987); CharLeS A. WRIGHT \& ARTHUR R. MILLER, 10A FEDERAL PRACTICE AND PROCEDURE (CTVIL) 2d \& 2730, at 236-38 (2d ed. 1983). Often, civil rights actions will involve a question of fact regarding the defendant's intent or motive, thereby precluding summary judgment. See WRIGHT \& MILLER, supra \$ 2732.2, at 349-50. There is, however, no general bar to granting summary judgment in civil rights actions, and courts will grant summary judgment in these actions when the material facts are not in dispute or when there is no legal basis for the relief a plaintiff seeks. See id. at 362-65.

89. In particular, the City of Milwaukee argued that in 1991 it hired a new police chief who was an advocate of "community-oriented policing." Sinthasomphone, 878 F. Supp. at 150. Nevertheless, the City of Milwaukee conceded that the police department had "problems" with discrimination prior to 1991 . See id. at 149.

90. See id.

91. See id. at 150-51. The court, however, held that the City of Milwaukee could rely on evidence of corrective measures so that a jury could determine whether these measures remedied any policy of discrimination that existed prior to Konerak's murder. See id. at 151 .

92. Monell, 436 U.S. at 691 (citing Adickes v. S.H. Kress \& Co., 398 U.S. 144, 167-68 (1970) (emphasis added)). See also St. Louis v. Praprotnik, 485 U.S. 112, 127 (1987) (citing Adickes, supra).

93. The court's opinion lists a "few" of the "many" historic signs of a possible policy of discrimination by the police department. They include: (1) a 1984 opinion by the Court of 
The court's rulings regarding the factual viability of plaintiffs' discrimination claims are consistent with my argument that both racial and sexual subordination informed the police's improper response to Konerak's subjugation. This case also demonstrates that multidimensionality need not remain exclusively a creature of legal scholarship, but that it may (and should) influence civil rights cases brought to remedy acts of discrimination.

One final aspect of the Dahmer tragedy merits attention. The officers' racial and sexual bias not only subordinated Konerak but also privileged Dahmer. Affirming racial privilege, the officers accorded Dahmer deference and credibility-allowing him to settle his "spat" alone. Thus, the police subjected Konerak to further "domestic abuse. ${ }^{3924}$ Dahmer, meanwhile, negotiated a favorable resolution, from

Appeals for the Seventh Circuit upholding a jury verdict, which found that Mitwakee police officers conspired for twenty years to "cover up" a racially motivated shooting of a black man by white officess; (2) a 1972 finding by the Wisconsin Advisory Commission to the United States Commission on Civil Rights ("WAC") that "[t]he change of racism among policemen [wa]s not a new one, nor one foreign to Milwaukee"; (3) a 1979 finding by the Olfiec of Revenue Sharing that the Milwaukee Police Department "had engaged in procedures and policies that adversely affected employment opportunities for bleck police officers"; (\$) a 1981 conclusion by "consultants" that "a substantial degree of racial polarization [exists] vithin the [Milwaukee] police department"; (5) a 1991 study by the Wisconsin Fire and Police Commission "report[ingl overt racism and sexism at the Police Academy"; (6) a 1991 finding by the Milwaukee Citizen's Commission on Police-Community Relations "that several [Milwaukee] residents complained of 'racist and homophobic attitudes and a general lack of respect' from police officess"; (6) a 1993 finding by the Police Foundation, with which the Milwaukee mayor and chair of the Wisconsin Fire and Police Commission agree, that "institutionalized racism and sexism" in the Milwaukee Police Department "needs to be openly discussed and dealt with"; (7) a 1994 finding by the WAC that the "Milwaukee Police Department has for the past two decades 'manifested a police culture unsympathetic, and even antagonistic, in its dealings with minority communities of the City"'; and (8) a recommendation by the WAC that the Militualkee police department adopt "a clearly stated unambiguous policy against discriminatory practices." Sinthasomphone, 878 F. Supp. at 150.

94. The officers' inaction in the wake of Konerak's abuse mirrors the responses of law enforcement to male-female domestic violence cases where police have often failed to protect women from their battering husbands and lovers. See generally Susanne ML. Browne, Note, Due Process and Equal Protection Challenges 10 the Inadequate Response of the Pollee in Domestic Violence Situations, 68 S. CAL. L. REv. 1295 (1995); Developments in the Law: Legal Responses to Domestic Violence, 106 HaRV. L. REv. 1501 (1993); Amy Eppler, Note, Baltered Women and the Equal Protection Clause: Will the Constitution Help Them When the Police W'or't?, 95 YALE LJ. 788 (1986). In this context, the police inaction affirms gender hiemarchy, and "the state . . . is thus complieit in one of the most fundamental and extreme acts of male domination over promen in contemporary American society." Eppler, supra, at 790 (citing R DOBASH \& R. DOBASH, VIOLENCE AGANST WIVES: A CASE AGANST THE PATRLARCTI (1979); J. FLEAING, STOPPING WIFE ABUSE (1979); R. LANGLEY \& R. LEVY, WIFE BEATING, THE SILENT CrISIS (1977); D. MARTI, BATTEREd WIVES (Ist ed. 1976); E. PLCZEY, SCREAM QUIETYY OR THE NEGHEORS WILl HEAR (1974); S. SCHECHTER, WOMEN AND MALE VIOLERCE (1982)). Several courts have held 
his perspective, of the encounter. He maintained dominion over his home and Konerak, who in this context becomes his sexual property (read "it"). The efforts of Konerak and the black women, on the other hand, proved unavailing. Their attempts to secure protection were met with threats, disregard, slurs, jokes, and inaction. ${ }^{95}$

that police inaction to incidents of male-female domestic violence may support claims of sex discrimination (most of the victims of such abuse are women) in violation of the Equal Protection Clause of the Fourteenth Amendment. See, e.g., Freeman, 911 F.2d at 52; Balistreri v. Pacifica Police Dep't, 901 F.2d 696 (9th Cir. 1990); Pinder v. Comm'rs of Cambridge, 821 F. Supp. 376 (D. Md. 1993); Thurman v. City of Torrington, 595 F. Supp. 1521 (D. Conn. 1984).

95. One might argue, however, that the police responded to Konerak's (and Rivcra's) abuse solely out of anti-gay bias (they did not want to help a couple of "queers"). Indeed, one commentator has made such an observation and claims that "[i]f Konerak Sinthasomphone had been a young woman, the Milwaukee police would have responded very differently ....." Nancy E. Murphy, Note, Queer Justice: Equal Protection for Victims of Same-Sex Domestlc Violence, 30 VAL. U. L. REV. 335, 336 (1995). Not only does this sweeping statement fail to recognize police indifference to female victims of male domestic violence, it also completely rules out race and class as possible factors in the police treatment of Konerak and Dahmer. While I am mindful that heterosexist police, judges, and legislators often fail to treat incidents of gay and lesbian domestic violence seriously, see Carla M. Da Luz, A Legal and Soclal Comparison of Heterosexual and Same-Sex Domestlc Violence: Simllar Inadequacles in Legal Recognition and Response, 4 S. CAL. REV. L. \& WOMEN'S STUD. 251 (1994); Sandra E. Lundy, Abuse That Dare Not Speak Its Name: Assisting Victims of Lesblan and Gary Domestic Violence in Massachusetls, 28 NEW ENG. L. REV. 273 (1993); Ruthann Robson, Lavender Bruises: IntraLesbian Violence, Law and Lesbian Legal Theory, 20 GOLDEN GATE U. L. REV. 567 (1990); Denise Bricker, Note, Fatal Defense: An Analysis of Battered Woman's Syndrome Expert Tesllmony for Gay Men and Lesbians Tho Kill Abusive Partners, 58 BROOK. L. REV. 1379 (1993), Murphy, supra, we must also remain aware that racial and class biases may also influence their responses. Otherwise, we may suggest that race and class have no importance in the lives of gay people of color-that a homosexual orientation eclipses or otherwise overshadows racial and class statuses. The persistence of racial and class inequality speaks against such a conclusion. Furthermore, it is likely that the results of this scenario would have differed if the race of Dahmer and Konerak had been reversed or if the two women were white and upper-class. Indeed, the fact that "a large number of hate-motivated criminals tend to be young middle-class white males," Zwerling, supra note 21, at 545 (citing David Chang, Beyond Uncompromising Positions: Hate Crimes Legislation and the Common Ground Between Conservative Republicans and Gay Rights Advocates, 21 FORDHAM URB. LJ. 1097, 1101 (1994)); see also COMSTOCK, supra note 22, at 60 ("Regardless of the gender or race of the victim, perpetrators [of homophobic violence] are more likely to be white than of color . . . .'), provides an additional reason (besides homophobia) for law enforcement officers to treat anti-gay violence lightly. If the case, however, involves a person of color as the assailant and a white victim, racial biases might bring it greater attention. Therefore, both the Rivera and Dahmer cases could have had different results if the races of the assailants and the victims were inverted.

During the completion of this Article, the City of Milwaukee settled the suit with Konerak's estate and family, agreeing to pay them \$850,000. See Milwaukee to Pay $\$ 850,000$ to Family of Dahmer Victim, WASH. POST, Apr. 26, 1995, at A6. In a final show of "diplomacy" toward the Sinthasomphone family, the County of Milwaukee, upon discovering the terms of the settlement, asked Konerak's family to repay $\$ 65,000$ (of a total of $\$ 106,368$ ) in welfare 
As the Rivera, Venus Xtravaganza, and Dahmer tragedies illustrate, racial, class, and sexual subordination are interrelated. Several of these forces may contribute to a single act of discrimination, as the killing of Rivera and the police behavior in the Rivera and Dahmer tragedies reveal. These sources of disempowerment may also combine to limit an individual's life choices, as the short lives of Rivera, Venus, and the Dahmer victims demonstrate. Moreover, because race and class also create privilege, these statuses may offer some insulation from forces of oppression. ${ }^{96}$ For instance, the police deferred to Dahmer, who was white (and male), although they believed he was gay. Despite the multidimensional nature of social reality, prevailing gay and lesbian legal and political responses to sexual subordination, as Part III illustrates, omit racial and class inequality from analysis and, instead, focus almost exclusively upon the experiences of race- and class-privileged individuals. Consequently, gay and lesbian legal theory and political discourse fail to reflect the complexity of gay and lesbian experiences and exclude people of color and the poor from equality debates.

In this great gay mecca,

I was an invisible man, still

I had no shadow, no substance

No history, no place

No reflection ${ }^{97}$

\section{EsSentialist Legal THEORY aNd POLITCAL ACTON}

Although race, class, and sexual subordination actively interact in the lives of gay and lesbian people, gay and lesbian equality discourse invariably excludes racial and class inequity from analysis. The exclusion of race typically occurs when it is treated as analogous to-hence separate from-sexual orientation. For example, one gay theorist, William Paul, has specifically endeavored to determine whether "homosexuals are a minority group with issues identical to the movements for

benefits the family received during the past ten years. See Give Back Welfare, County Tells Family, WIS. ST. J., Apr. 27, 1995, at 3B. A "county spokesman" stated thal such demands are routinely made when families receive "windfalls" from other sources. See id.

96. See infra. pp. 605-08 (discussing how class privileges gays and lesbians).

97. Riggs, Tongues Untied, in BROTHER TO BROTHER, supra note 2, at 203. 
racial and ethnic minority civil rights. ${ }^{998}$ To reach his conclusion that "people with a homosexual orientation do constitute a minority group," Paul purports to analyze the "differences in the discrimination directed by the majority toward Lesbians and Gay men on the one hand and toward racial and ethnic minorities on the other."100 Although Paul acknowledges passively that gays and lesbians "are members of all races, both sexes, and all socioeconomic groups,"101 his analogy of racial "minorities" to gays and lesbians treats the two as mutually exclusive groups, thereby omitting gays and lesbians of color. A statement by Benjamin Schatz, the Executive Director of the American Association of Physicians for Human Rights, captures, rather strikingly, the essentializing effects of analogical reasoning in gay and lesbian political discourse. During an interview in which Schatz explains how the AIDS epidemic has forced gay and bisexual men to reveal their sexual identities, Schatz states that "AIDS [has] de-invisibilized us . . . . The biggest difference between $u s$ and blacks was that we were invisible."102 Clearly, Schatz excludes "blacks" from his population of "gays" ("us" and "we"). Thus, black gays are "invisible" under Schatz's analogy. ${ }^{103}$

Race and sexuality analogies, as this Part demonstrates, also preclude an examination of the ways in which racial domination and privilege impact gay and lesbian people. By omitting people of color and ignoring white racial privilege, the analogies obscure the potent social role of race. ${ }^{104}$

98. William Paul, Minority Status for Gay People, in HOMOSEXUALITY: SOCLAL, PSYCHOLOGICAL, AND BIOLOGICAI ISSUES 351, 353 (William Paul et al. eds., 1982).

99. Id. at 368.

100. Id. at 355.

101. Id. at 353.

102. Jeffrey Schmalz, Gay Politics Goes Mainstream, N.Y. TMES, Oct. 11, 1992 (Magazine), at 29 (emphasis added).

103. Mary Eaton has observed that:

analogical reasoning inserts a space between the things analogized that may be narrowed according to degrees of logical correspondence, but remains ultimately unbridgeable. The effect of this is plain: The possibility of cross-identification or consubstantial oppression is utterly unintelligible in a mode of reasoning that depends upon a separation between identities of oppressions. "Black homosexual" is therefore an oxymoron in an analogical comparison of blacks and homosexuals.

Eaton, Homosexual Unmodified, supra note 12, at 62.

104. See Jane S. Schacter, The Gay Civil Rights Debate in the States: Decoding the Dlscourse of Equivalents, 29 HARV. C.R.C.L. L. REV. 283, 297 (1994) (attempts to compare homosexuals and other groups "erases 'vertical' differences within a group . . . [and] 'horizontal' differences across the spectrum of legally protected groups"). Cf. Trina Grillo \& Stephanic $M$. 


\section{A. The Exclusion of Race and Class from Gay and Lesbian Legal Theory}

\section{Essentialist Legal Solutions to Gay and Lesbian Inequality}

Gay and lesbian legal theorists embrace essentialism by excluding issues of race from analysis. ${ }^{105}$ As a result, the legal theories and solu-

Wildman, Obscuring the Importance of Race: The Implicalion of Mfaking Comparisors Betreen Racism and Sexism (or Other-Isms), 1991 DUNE LJ. 397, 401 (1991) ("Comparing sexism to racism perpetuates patterns of racial domination by marginalizing and obscuring the different roles that race plays in the lives of people of color and of whites."). Comparisons of recial and sexusl subordination abound in both gay legal theory and politieal discourse. See, e.g. Robert Dawidoff \& Michael Nava, Why Martin Luther King, Jr. Is a Gaj-Rights Hero: HLs Life and His Message Resonate Bejond the Flght Against Racial Prejudlce, LA. TuEs, Jan. 16, 1994, at M5; William Eskridge, Race and Serual Orfentallon in the Anlitary. Ending the Apartheid of the Closet, RECONSTRUCTION, No. 2, at 52 (1993); Gerald Gillerman, Dred Seott Revisited: A Comment On Bowers v. Hardwick, 30 Bost. BAR J. 4 (1986); Note, The Constihstional Status of Sexual Orientation: Homosexuality as a Suspect Clossification, 98 HARV. L. REV. 1285 (1985). These comparisons separate racial privilege and subordination from sexual orientation and thereby preclude discussions of power differentials created by recial hierarchy writhin the population of gays and lesbians and between white gay people and people of color. 105. Before I develop this argument, I wish to note, preliminarily, that lesbian theorists have already criticized gay male and feminist legal theorists and, more so, political ectivists for failing to acknowledge the intersection of sexism and homophobia, equating lesbian and gay male experience, and omitting lesbian issues from analysis. See, e.g., RUTHuNoN ROBsoN, LesbLaN (OUT)LAW: SURVIVAL UNDER THE RULE OF LAW 21-22 (1992). Some theorists, most notably Robson, are attempting to construct a more specific, lesbian-centered "lesbian legal theory." See, e.g., id; Paula L. Ettelbrick, Who Is a Parent?: The Need to Devalop a Lesbian Conscious Family Law, 10 N.Y.L. SCH. J. HUM. RTS. 513 (1993); Ruthann Robson, Embadimen(s): The Possibilities of Lesbian Legal Theory in Bodies Problentatied by Postmodemisms and Feminisms, 2 LAW \& SEXUALTY 37 (1992); Ruthann Robson \& S.E. Valentine, Lov(f)ers: Lesbians as Intimate Partners and Lesbian Legal Theory, 63 TEMPLE L. REV. 511 (1990); Ruthann Robson, The Specter of a Lesbian Supreme Court Justice: Problems of Identiby in Lesbian Legal Theorizing, 5 ST. THOMAS L. REv. 433 (1993). Hence, there is a history of anti-essentinlist criticism, focusing on "gender," in gay and lesbian legal theory and politieal discourse that predates the scholarship exploring race and sexual orientation.

Although lesbian theorists have correctly criticized the respective "male-centered" and heterosexist nature of gay and feminist theory and political action, they too have foced criticism for failing to consider how race informs lesbian experience. See Shane Pheran, Germig Spe-

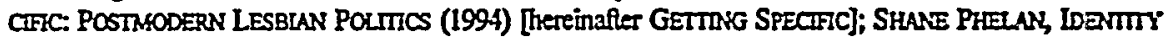
POLITICS: LESBIAN FEMINISM AND THE LIMITS OF COMaMUNTY 161-66 (1989) [hereinufter IDENTITY Potmcs]; Arriola, Gendered Inequality, supra note 12, at 132-35; Jnelsic Goldsby, Queen for 307 Days, in AFREKEIE, supra note 9, at 165-88; LORDE, Man Child: A Black Lesbian Feminist's Response, in SISTER OUTSIDER, supra note 9, at 72; LORDE, An Open Letter to Hany Dab; in SISTER OUTSIDER, supra note 9, at 66; Eaton, At the Intersection, supra note 12, at 212-18; Petersen, supra note 12 at 118-37; Barbara Smith \& Beverly Smith, Across the Kifchan Table: 
tions they propose for "gay" and "lesbian" inequality may have limited benefits-if any-for people of color and the poor. Recent works by William Eskridge on same-sex marriage ${ }^{106}$ serve as a perfect example of gay and lesbian essentialism and the problematic impact it has upon theory. In these publications, Eskridge advocates legal recognition of same-sex marriage. ${ }^{107}$ A significant portion of Eskridge's analysis attempts to dispose of the concems of lesbian theorists who argue that achieving legal legitimacy for gay and lesbian unions would actually affirm traditional power differences supplied by gender, assimilate gays and lesbians into middle-class society, and divide the gay and lesbian community along race, class, and gender lines. ${ }^{108}$ The lesbian critiques of the pursuit of same-sex marriage have been the site of the most contentious anti-essentialism debate-primarily around issues of "gender"-in gay and lesbian legal theory and politics. ${ }^{109}$ As my discussion

A Sister to Sister Dialogue, in THIS BRJDGE CALLED MY BACK, supra note 1, at 120-24;. Thus, while the gender-based lesbian feminist critiques of gay and lesbian legal theory and politics support my thesis that gay and lesbian equality theory and activism are essentialist, they generally have not provided much illumination on issues of race in lesbian experience. I note, however, that most of the racial critics in gay and lesbian legal theory are lesbian.

106. See WILLIAM N. ESKRIDGe, JR, THE CASE fOR SAMESEX MARRIAGE: FROM SEXUAL LIBERTY TO CIVllzed COMMmiment (1996) [hereinafter THE CASE fOR SAME-SEx MARRIAGE]; William N. Eskridge, Jr., A History of Same-Sex Marriage, 79 VA. L. REv. 1419 (1993). This Article initially addressed arguments Eskridge makes in A History of Same-Sex Marriage. I have extended my analysis to focus upon arguments Eskridge develops in The Case for Same-Sex Marriage, which was published during the completion of this Article.

107. See generally sources cited supra note 106.

108. For a survey of these criticisms, see generally Paula Ettelbrick, Since When Is Marriage a Path to Liberation?, in LESBIANS, GAY MEN, AND THE LAW 401 (William B. Rubenstein ed., 1993) [hereinafter LESBIANS, GAY MEN AND THE LAW]; Nancy D. Polikoff, We Will Get What We Ask For: Why Legalizing Gay and Lesbian Marriage Will Not "Dismantle the Legal Structure of Gender in Every Marriage," 79 VA. L. REv. 1535 (1993); Robson \& Valentine, supra note 105.

109. In addition to the debates cited supra, note 108, Law and Sexuality: A Review of Gay and Lesbian Legal Issues, a joumal produced by students at Tulane Law School, has sponsored a symposium on the issue and published the papers presented at the forum. See Nitya Duclos, Some Complicating Thoughts on Same-Sex Marriage, 1 L. \& SEXUALITY 31 (1991) (arguing that members of the gay and lesbian community will not uniformly benefit from the legalization of same-sex marriage due to racial and class differences); Mary C. Dunlap, The Lesbian and Gay Marriage Debate: A Microcosm of Our Hopes and Troubles in the Nineties, 1 L. \& SExuALITY 63 (1991) (arguing that the legalization of same-sex marriage will help counter societal homophobia); Nan D. Hunter, Marriage, Law and Gender: A Feminist Inquin, 1 L. \& SExuAuITY 9 (1991) (arguing that same-sex marriage will help subvert gender-based distinctions in marriage). Other scholars and attomeys have also contributed to the debate. See ESKRJDGE, THE CASE FOR SAME-SEX MARRIAGE, supra note 106, at 51-85 (1996) (defending efforts to legalize same-sex marriage and responding to lesbian critiques); Ruth Colker, Marriage, 3 YAlE J.L. \& FEMINISM 321 (1991) (arguing that gays and lesbians should seek to make the private and govemmental 
benefits of marriage available for everyone); Eskridge, \& History of Same-Sex Mfarioge, supra note 106, at 1419 (defending efforts to legalize same-sex marriage and responding to lesbinn critiques); Thomes Stoddard, Why Gay People Should Seek the Right to Mam; in LesBunts, GAY MEN, AND THE LAW, supra note 108, at 398 (same); Evan Wollson, Crossing the Threshold: Equal Marriage Rights for Lesbians and Gay Men and the Intra-Community Crillque, 21 N.Y.U. REv. L. \& SOC. ChaNGE 567 (1995) (same).

Outside of these contentious debates, gay and Iesbian legal theorists, civil rights attomeys, and other commentators have extensively explored legal issues pertaining to same-sex marriage, giving gay and lesbian marriage extreme priority in the contemporary legal struggle for gay and lesbian equality. For a survey of the voluminous scholarship on same-sex maniage, see generaily sources cited supra and supra note 108; Jennifer Gerarda Brown, Competitive Federalism and the Legislative Incentives to Recogrize Same-Sex Marrloge, 68 S. CAL L. REV. 745 (1995); Anne M. Burton, Gay Marrioge-A Modern Proposal: Apphing Bachr v. Lewin to the International Covenant on Civil and Political Rights, 3 IND. J. GLOBAL LEGAL STUD. 177 (1995); Robert L. Cordell, II, Same-Sex Marriage: The Fundamental Right of Marriage and an Examination of Conflict of Laws and the Full Fallh and Credit Clause, 26 Coluns. HuM. RTS. Lo REv. 247 (1994); Barbara J. Cox, Same-Sex Marriage and Cholce-of-Law: If He Mamy in Hawril, Are Whe Still Married When We Retum Home?, 1994 Wis. L. REv. 1033 (1994); Jonathon Dietriech, The Lessons of the Lawr Same-Sex Marrloge and Bathr v. Lewin, 78 MARQ. L. REV. 121 (1994); Lisa Farabee, Marriage, Equal Protection, and New Judiclal Federallsm: A hew From the States, 14 YALE L. \& POL'Y REv. 237 (1990); Andrew H. Friedman, Same-Sex Mfarriage and the Right to Privacy: Abandoning Seriphural, Cononical, and Nohural Law Based Definitions of Marriage, 35 How. LJ. 173 (1992); Vincent C. Green, Same-Ser Adoptlon: An Alfernative Approach to Gay Marriage in New York, 62 BRook. L. REv. 399 (1996); Joseph W. Hovermill, A Conflict of Laws and Morals: The Choice of Law Implicallons of Harali's Recogniltion of Same-Sex Marriages, 53 MD. L. REv. 450 (1994); Christine Jax, Same-Sex Marriage-Hhy Not? 4 WIDENER J. PUB. L. 461 (1995); Nancy Lingeman \& Kenneth May, For Better or for Worse, In Sichness and in Healh, Until Dealh Do Us Parl: A Look at Same-Ser Marriage in Hawail, 16 U. HAw. L. REv. 447 (1994); Richard D. Mohr, The Case for Gay" Marriage, 9 Notre DAME J.L. EthICS \& PUB. PoL'Y 215 (1995); William B. Rubenstein, We Are Family: A Reflection on the Search for Legal Recognilion of Lesblan and Goy Relatlonships, 8 J.L. \& POL. 89 (1991); Edward A. Slavin, Jr., What Mfakes a Mfarioge Legal: Here Is the Case for Legalizing Gay Relationships, 18 HUM. RTS. Q. 16 (1991); Jeffrey J. Swart, The Hedding Luat-Who Is Inviled?: Hawail, Same-Sex Marriage, and Emerging Realities, 43 ExoRY LJ. 1577 (1994); Erik J. Toulon, Call the Caterer: Hawail to Host First Same-Sex Mlariage, 3 S. CAL. REv. L. \& WoMen's STUD. 109 (1993); Kevin A. Zambrowicz, "To Love and Honor All the Days of Your Life": A Corstitutional Right to Same-Sex Marrlage?, 43 CATt. L. REv. 907 (1994); Marty K. Courson, Note, Baehr v. Lewin: Hawall Takes a Tentative Step 10 Legalize Same-Sex Marriage, 24 GoLden GATE U. L. REV. 41 (1994); Anthony Dominic D'Amato, Note, Conflict of Laws Rules and the Interstate Recognillon of Same-Sex Marriages, $1995 \mathrm{U}$. ILL. L. REV. 911 (1995); Otis R. Damslet, Note, Same-Sex Marrloge, 10 N.Y.L. SCr. J. HuR. RTS. 555 (1993); William M. Hohengarten, Note, Same-Sex Marriage and the Right of Privacy; 103 YALE LJ. 1495 (1994); Note, In Sichness and in Health. In Howall and There Else?: Conflict of Laws and Recognition of Same-Sex Marrlages, 109 HARV. L. REY. 2038 (1S96); Edward J. Juel, Note, Non-Traditional Family Values: Providing Quasl-Afarllal Rights to SameSex Couples, 13 B.C. TuRD WoRLD LJ. 317 (1993); Thomos M. Keane, Note, Aloha, Marrloge? Constitutional and Choice of Law Arguments for Recognition of Same-Sex Marrigges, 47 STAN. L. Rev. 499 (1995); Scott K. Kozuma, Note, Bachr v. Lewin and Same-Sex Mlarrlage: The Continued Struggle for Political and Human Legitimacy, 30 WILLAMETIE L. REV. 891 (1994); Note, The Legality of Homosexual Marriage, 82 YALE LJ. 573 (1973); Claudia A. Lewis, Note, 
will reveal, however, the lesbian feminist critiques themselves have also, at times, suffered from a lack of racial analysis.

Eskridge criticizes lesbian feminists who argue that gays and lesbians should not pursue marriage because that institution has traditionally subordinated women. ${ }^{10}$ Eskridge argues that the fact

[t] hat Western marriages have traditionally been the social instrument by which women have been subordinated does not mean that marriage "causes" that subordination. Women's subordination may be more deeply related to social attitudes about gender differences than to the formal construct of marriage per se. If that is true, same-sex marriage does not buy into a rotten institution; it only buys into an institution that is changing, as women's roles and status are changing in our society. ${ }^{11}$

Eskridge further notes that the feminist critique of marriage as a major source of women's oppression "comes perilously close to essentializing marriage as an inherently regressive institution ....'112 Eskridge's general observation regarding the essentialist nature of the lesbian feminist critique is correct. In particular, the negative feminist

From This Day Forward: A Feminine Moral Discourse on Homosexual Marriage, 97 YALE LJ. 1783 (1988); Candace L. Sage, Note, Sister-State Recognilion of Valid Same-Sex Marriages: Baehr v. Lewin-How Will It Play in Peoria?, 28 IND. L. REV. 115 (1994); James Trosino, Note, American Wedding: Same-Sex Marriage and the Miscegenation Analogy, 73 B.U. L. REV. 93 (1993).

In addition, same-sex marriage has been the subject of substantial litigation and scrutiny by state legal authorities. See ESKRIDGE, THE CASE FOR SAME-SEX MARRIAGE, supra note 106, at 232-33 \& n.24 (listing numerous cases rejecting same-sex couples' petitions for equal marriage rights), and $248-49$ \& n.18 (same; listing opinions of attomeys general of several states who have argued that their states' marriage laws can constitutionally prohibit same-sex marriage).

110. See, e.g., Ettelbrick, supra note 108, at 402 (stating that marriage is "steeped in a patriarchal system that looks to ownership, property, and dominance of men over women as its basis . . . ."); Polikoff, supra note 108, at 1536 ("desire to marry . . . betrays the promise of .. . radical feminism"); Robson \& Valentine, supra note 105, at 535 ("Marriage has remained interwoven with both the development and the perpetuation of patriarchy and women's status within patriarchy."). The lesbian, gender-based opposition to marriage arises out of feminist criticism. Robson \& Valentine, supra note 105 at 535 ("Underlying the lesbian critique of marriage is the gendered perspective on marriage developed by feminists."). For a sampling of feminist critiques of mamiage see MICHELE BARRETT \& MARY MCINTOSH, THE ANT-SOCLAL FAMALY (1982); SHULAMTH FIRESTONE, THE DIALECTIC OF SEX: THE CASE FOR FemINIST REVOLUTION (1970); PATEMAN, The SEXUAL CONIRACT (1988); Sheila Cronan, Marriage, in RADICAL FEMINISM 213-21 (Anne Koedt et al. eds., 1973). See also Alice Echols, Daring to Be Bad: Radical FEMmISM IN AMERICA 1967-75 (1989) (cataloguing feminist anti-marriage politics).

111. See Eskridge, A History of Same-Sex Marriage, supra note 106, at 1488. 112. Id. 
depiction of marriage contrasts with the portrait of marriage advanced by feminist legal scholars and social theorists of color. Feminists of color have challenged this negative portrait of marriage (and the privacy sphere more broadly), noting that women of color often view marriage and family life as a "site of solace and resistance against racial oppression." 113

Eskridge, however, covers the narrow feminist critique of marriage with his own overlay of essentialism by failing to examine the impact, and even dismissing the importance, of racism and poverty on the claims he makes. For example, Eskridge opposes the contention that the pursuit of same-sex marriage is a negative attempt to "assimilate" mainstream norms, which gay and lesbian politics should seek to undermine. ${ }^{114}$ Eskridge argues that gays and lesbians "are gender rebels because that role has been thrust upon us by oppressive dividing practices, including legal discriminations like the exclusion from marriage. If those dividing practices were to collapse, we might tend to meld back into society's mainstream, which does not inevitably strike me as baleful."115 Assume for the sake of argument that gays and lesbians are "gender rebels" and that "dividing practices" of "gender" exclusion exist apart from other forms of social inequality. Even under these assumptions, the people who would likely benefit from social change limited to gender-linked "dividing practices," in particular the exclusion from marriage, and quietly "meld back into society's mainstream" prob-

113. Roberts, supra note 13, at 1470-71; see also HOOKs, FROM MAARG TO CENTE, supra note 13, at 37 (family life and marriage allow black women to "experience dignity, self-worth, and a humanization that is not experienced in the outside rorld."). This observation, hoviever, is not without its problems. Because women of color may view the home as a sanetuary against racist oppression, they may decline to seek state assistance (which they approach with distrust), when they suffer domestic abuse from their male partners. See Crenshaw, Bopping the Mrargins, supra note 13, at 1257; Miriam H. Ruttenberg, A Feminist Crillque of Mandaton' Arrest: An Analysis of Race and Gender in Domestic Violence, 2 AM. U. J. GeNDER \& L. 171, 182-84 (1994). In addition, lesbians of color may face homophobic violence and marginalization in the home and battering from their intimate partners.

114. Eskridge, A History of Same-Sex Marrloge, supre note 106, at 1488. Again, lesbian theorists have been the primary source of this criticism. Paula Ettelbrick, for example, argues that "[t]he thought of emphasizing our sameness to mantied heterosexuals in order to obtain [the right to marry] terrifies me . . . . We end up mimicking all that is bad about the institution of marriage in our effort to appear to be the same as straight couples." Ettelbrick, supro note 108, at 403. Similariy, Robson and Valentine argue that "[p]ursuing state approval of [lesbian] relationships . . . forces lesbian partners into potentially damaging attempts to calibmite their lives to conform to heterosexual models." Robson \& Valentine, supra note 10S, at S39. See also Polikoff, supra note 108, at 1536 ("desire to many . . . is an attempt to minic the worst of mainstream society, an effort to fit into an inherently problematic instiation.").

115. Eskridge, A History of Same-Sex Marriage, supra note 106, af 1490 (emphasis added). 
ably do not face multiple forms of social and economic oppression. Also, poor gays and lesbians and gays and lesbians of color, unlike the white and affluent, are excluded from society before they ever discover their sexual orientation. Therefore, they cannot meld back into the mainstream-they have never been part of it. ${ }^{116}$ Furthermore, both sides of the assimilation debate obscure the extent to which many gays and lesbians, due to race, class and gender privileges, are already closely linked to and "assimilated" within mainstream social power structures.

Eskridge also confronts lesbian theorists who argue that the legalization of same-sex marriage will benefit primarily "affluent white male couples"117 and divide the gay and lesbian community among racial, class, and gender lines. Lesbian theorist Paula Ettelbrick has most vigorously stated this argument. Ettelbrick believes that legal and political efforts aimed at legalizing same-sex marriage reflect a universal "need to be accepted by the broader society."118 She, nevertheless, contends that

[t]hose closer to the norm or to power in this country are more likely to see marriage as a principle of freedom and equality. Those who are more acceptable to the mainstream because of race, gender and economic status are more likely to want the right to marry. It is the final acceptance, the ultimate affirmation of identity.

On the other hand, more marginal members of the lesbian and gay community (women, people of color, working class and poor) are less likely to see marriage as having relevance to our struggles for survival. After all, what good is the affirmation of our relationships (that is, marital relationships) if we are

\section{As James Baldwin poignantiy stated:}

A black gay person who is a sexual conundrum to society is already, long before the question of sexuality comes into it, menaced and marked because he's black or she's black. The sexual question comes after [temporally] the question of color; it's simply one more aspect of the danger in which all black people live.

Richard Goldstein, "Go the Way Your Blood Beats": An Interview Wilh James Baldiwin, in LESBIANS, GAY MEN, AND THE LAW, supra note 108, at 43. See also Jewelle Gomez, Repeat After Me: We Are Different. We Are the Same., 14 N.Y.U. REv. L. \& SOC. CHANGE 935, 938 (1986) ("B]y the time I leamed that being gay was a reality with which I would have to reckon, I was already struggling with another reality-black skir-that was immensely more devastating in my daily life." $)$.

117. Eskridge, A History of Same-Sex Marriage, supra note 106, at 1491-93.

118. Ettelbrick, supra note 108, at 403. 
rejected as women, black, or working class? ${ }^{119}$

Ettelbrick's argument is compelling. Because most gays and lesbians of color remain invisible and marginalized within the larger gay and lesbian community, ${ }^{120}$ it is extremely unlikely that a marriage license will close much of the gulf between them and the center of a heterosexual society that is stratified by race, class, gender, and sexuality. On the other hand, gays and lesbians who are privileged by interlocking racism, sexism, and class inequality stand a greater chance of blending - if they have not already-into this multi-oppressive society. As a result, persons who face multiple oppressions and those who possess social privileges will likely have disparate views on the ability of marriage to place them within structures of power and acceptability and to transform radically their lives.

Eskridge calls this assertion the "new insiders argument" "321 because it suggests that privileged gays and lesbians can marry and create a class of "insiders" who fit neatly within the larger non-gay and lesbian community. 122 The "new insiders argument" "underwhelms"123-even "baffles"124_Professor Eskridge. Eskridge dismisses this racial, gender, and class critique by noting that "there is no evidence-neither polls, surveys nor theoretical models-suggesting that the marriage option would be disproportionately exercised by rich gay men as compared to people of color or lesbians or less affluent homosexuals."125 The lack of "evidence" documenting the opinions of men of color, lesbians, and the poor regarding the gay marriage movement, versus those of white affluent gay men, may have less to do with their tacit acceptance of and excitement for the movement than with their exclusion from and invisibility within gay and lesbian political discourse. ${ }^{126}$

119. Ettelbrick, supra note 108, at 403-04. See also Duclos, supra note 109, at 51 n.75 ("Lesbians and gay men who are oppressed because of their race, culture, and/or disability will probably not find that the respectability marriage confers is adequale to ameliorate these kinds of discrimination.").

120. See supra p. 562; see also infra pp. 604-05.

121. Eskridge, 1 History of Same-Sex Marriage, supra note 106, at 1491.

122. See id. Again, many gays and lesbians may already fit neatly within structures of porier.

123. Id. at 1492.

124. Eskridge, THE CASE For SaMe-Sex Marpuage, supra note 106, at 82-83.

125. Id. at 83.

126. Reflecting on the invisibility of black men in gay political discourse, Joseph Beam commented that "[m]ore and more each day, as I looked around the riell-stocked shelves of Giovanni's Room, Philadelphia's gay, lesbian, and feminist bookstore where I rorked, I won- 
Moreover, substantial sociological, historical, and anthropological research demonstrates that Africans, American blacks, and other nonwhite cultures place tremendous importance on "extended families,"127 rather than rigid nuclear bodies, as a means of social organization and child rearing. ${ }^{128}$ These patterns result from economic necessity and cultural practice. ${ }^{129}$ Furthermore, Census data and significant sociological studies indicate that heterosexual blacks "exercise the marriage option" less often than their white counterparts. ${ }^{130}$

Although this family structure research and statistical data do not explicitly focus on gays and lesbians, it is possible that gays and lesbians of color who grew up in this tradition and who have similar economic backgrounds, will replicate these family structures. Indeed,

dered where was the work of Black gay men." Beam, Introduction to IN THE LIFE, supra note 9, at 14.

127. "An extended family is one in which individual relationships extend beyond the conjugal family-spouses and children-and include daily interaction with, and responsibilities for, other family members such as aunts, uncles, grandparents, and cousins." Gilbert A. Holmes, The Extended Family System in the Black Community: A Child Centered Model for Adoption Pollay, 68 TEMP. L. REV. 1649, 1658 (1995).

128. See id. at 1658-67. See also ANDREW BLLINGSLEY, ClMmEng JACOB'S LADDER: THE ENDURINO LEGACY OF AFRICAN-AMERICAN FAMILIES 94-95 (1992); ELMER P. MARTIN \& JOANNE MARTIN, THE BLACK EXTENDED FAMILY (1978); THE EXTENDED FAMILY IN BLACK SOCIETIES (Demitri B. Shimkin ct al eds., 1978); CAROL B. STACK, ALL OUR KIN: STRATEGIES FOR SURVIVAL IN A BLACK COMMUNITY (1974); Madeleine L. Kurtz, The Purchase of Families into Foster Care: Two Case Studies and the Lessons They Teach, 26 CONN. L. REV. 1453, $1467-68$ (1994) ("Extended kinship networks are found to be particularly prevalent and important within African-American communitics."); Dorothy E. Roberts, Motherhood and Crime, 79 IOWA L. REV. 95, 132-33 ("mothering" in black community involves "a rich tradition of women-centered, communal childcare. These cooperative networks include members of the extended family ... as well as nonblood kin and neighbors."); Note, Into the Mouths of Babes: La Familia Latina and Federally Funded Child Welfare, 105 HARV. L. REV. 1319, 1322-23 (1992) ("To Latinos, familia brings to mind much more than the nuclear family; familia encompasses broad, extended family ties including many generations of aunts, uncles, grandparents, and cousins.") (citing ANGELA L. CARRASQUILLO, HISPANIC CHILDREN AND YOUTH IN THE UNTED STATES 70, $72-73$ (1991)); William A. Vega, Note, Hispanic Families in the 1980s: A Decade of Research, 52 J. MARRIAGE \& FAM. 1015, 1016-17; .

129. See generally sources cited supra note 128. See also Jean Koh Peters, The Roles and Content of Best Interests in Client-Directed Lawyering for Children in Child Protective Proceedings, 64 FORD. L. REV. 1505, 1546 (1996) ("shared parenting responsibilities among kin' predominate in many Caribbean, African, and African American contexts, in long-standing cultural patterns, and as a hedge against poverty.") (citing Carol B. Stack, Cultural Perspectives on Child Welfare, 12 N.Y.U. REv. L. \& SOC. CHANGE 539, 541 (1983)).

130. See generally ANDREH CHERLI, MARRIAGE, DNORCE AND RE-MARRIAGE (2d ed. 1992). Several sociological studies have attributed this disparity to class differences. Specifically, these studies argue that individuals seek partners with financial and economic resources. These studies therefore conclude that the prevalence and persistence of poverty among blacks renders marriage less beneficial or attractive to many of them. See generally WiLLLAM JULuUs WILSON, THE DECLINING SigmifCANCE OF RACE (1978). 
many gays and lesbians of color have documented the significance of extended family networks in their writings. ${ }^{131}$ Noticeably absent from their scholarship, however, are vigorous arguments in support of samesex marriage and nuclear family models. Also, several gays and lesbians of color have recently voiced criticism of the gay and lesbian marriage movement. ${ }^{132}$

Thus, under a multidimensional analysis the argument that gay and lesbian interest in and benefits from same-sex marriage may vary under different racial, class, and ethnic contexts is not "baffling." Rather, it speaks to the cultural differences and the incongruent dispersal of social and economic power within the population of gays and lesbians. Accordingly, lesbians, men of color, and the poor may place less stock in marriage as a means of ending, or substantially reducing, their oppression. Gays and lesbians of color, if their writings are a reliable indication, have been generally ambivalent towards the same-sex marriage issue. Furthermore, Eskridge himself concedes that "lesbians . . . contribute more than their share of marriage critics."

131. See, e.g., GOMEZ, I Lost It at the Movles, in FORTY-THREE SEPTEMERS, supra note 9, at 9 (describing importance of author's relationship with her grandmother and mother, with whom she grew up, and relating the process of coming out to them); HeaphIL, Allss Emily's Grandson Fron't Hush His Mouth, in CEREMONIES, supra note 9, at 43-46 (describing Hemphill's relationship with his grandmother and the process of revealing his sexual orientation to her). The prevalence and importance of extended family networks in communities of color does not mean, however, that people of color do not many or wish to marry. Rather, it suggests that people of color may place less reliance upon marriage as an institution of social organization, child rearing, and freedom.

132. See David Dunlap, Some Gay Rights Advocales Question Drtie to Defend Same-Sex Marriage, N.Y. TIMES, June 7, 1996, at A12 ('there [ere] several causes "more fundamental to survival' for gay men and lesbians .... .") (quoting black lesbian activist); $l d$. (reporting view of Keith Boykin, executive director of the National Black Gay and Lesbian Leadership Fonum, that marriage movement is "marching down the wrong path and running a disastrous course" given divisions within the gay and lesbian community, lack of public support, and the pervasiveness of other forms of discrimination against gays and lesbiuns).

133. ESKRIDGE, THE CASE FOR SAME-SEX MAARRIAGE, supra note 106, at 83. Eshridge also dismisses the lesbian critiques by citing recent surveys in gay and lesbian periodicals that purport to indicate overwhelming support for same-sex marriage among lesbians and gays. See lid at 78-79 (citing Janet Lever, Sertal Revelations, THE ADVOCATE, Aug. 1994, at 17, 24; Readers Favor Legal Marriage, PARTNERS MAGAZINE FOR GAY AND LESBIAN COUPLES, July/Aug. 1990, at 1; Elizabeth Rhodes, New Ties That Bind: Same-Sex Couples Challenge the System to Goin Legal Recognition of Their Commitments to Each Other, SEATTE TmiES, July 21, 1991, $\S \mathrm{K}$, at 1). Polls taken by gay and lesbian magazines, however, tend to be extremeby poor predictors of gay and lesbian opinion because these polls are invariably based on biased samples that exclude the poor and people of color. See infra pp. 605-08. Accordingly, the surreys Eskridge cites likely tell us more about the desire for same sex-marriage among the while and affluent, rather than the views held by people of color and the poor.

Eskridge also notes that "lesbians of color in 1920 s Harlem" passed as "men" in order to 
By stark contrast, several white and economically advantaged gay male legal and political commentators consider the legalization of samesex marriage crucial to the(ir) struggle(s) for legal, political, and social equality. Eskridge, for example, claims that "[m]arriage is the most important right the state has to offer ...."134 He argues that once gay marriages have "slowly blossom[ed] . . . like dandelions in springtime,"135 they will spawn a multitude of dramatic benefits for gays and lesbians. In particular, Eskridge contends that same-sex marriage will "undermine social homophobia,"136 render the "insider-outsider issue . . . almost irrelevant" for the "next generations of homosexual youth,"137 provide "discipline" for gay men, ${ }^{138}$ and help working-class lesbians

obtain marriage licenses. ESKRIDGE, THE CASE FOR SAME-SEX MARRIAGE, supra note 106, at 83. Eskridge's "evidence" misses the point. The mere fact that some black lesbian couples "legally" married in the 1920 s does not tell us much about general attitudes of gay and lesbian people of color toward same-sex marriage in the 1920 s or, more relevantly, in the 1990s. Second, the occurrence of gay or lesbian marriage standing alone does not prove its importance as a vital liberation tool, nor does it demonstrate the comparative views and gains of people of color and affuent gay white men towards and from marriage.

134. Id. at 8 (emphasis added).

135. Id. at 81 .

136. Id. at 82 .

137. Id. Even if same-sex marriage could undermine homophobia, this limited change would not eliminate the "insider-outsider" issue for young gays who are poor, female, or of color.

138. Id. at 83. Eskridge states that

[i]n order to achieve committed relationships gay men need the discipline of marriage more than lesbians do. Gay men are like Ulysses, who directed that he be bound to the ship's mast as it passed the Sirens, sea creatures whose seductive voices enticed men to their deaths. Likewise, gay men realize that they tend to lose their balance Id. and succumb to private sirens if they are not socially and even legally constrained.

Eskridge argues that lesbians, by contrast "have achieved a balance of sexual freedom and interpersonal commitment" and that same-sex marriage will "civilize】 gay men by making them more like lesbians." Id. at 83-84.

Eskridge overstates the power of law. He fails to demonstrate how "legal constraints" can push gay men toward (rather than repel them from) committed relationships. It is interesting to note that the "law" in some states outlaws gay male sexual practice but has not stopped many gay men from engaging in sex. According to Eskridge, their sexual lives are in fact wanton-cunbalanced" and "uncivilized."

Furthermore, Eskridge's Homerian metaphor seems to accept, though possibly unintentionally, caustic stereotypes regarding gay male sexual practice. Even if such stereotypes were true, Eskridge's argument, extended to its logical conclusion, implies a false dichotomy between heterosexual and gay men. Under Eskridge's analysis, gay men, who cannot legally marry, are vulnerable to "seductive voices"; heterosexual males, for whom marriage is available, are seemingly immune from-or "deaf" to-these forces, supposedly, by the "social" and "legal" "constraint" of marriage. The prevalence of infidelity, rape, incest, pomography, and use of female sex workers by heterosexual males (married and unmarried) speaks against such a dichotomy 


\section{gain custody of their children. ${ }^{139}$ Furthermore, Thomas Stoddard,}

and against a conclusion that marriage "tames" male sexuality. Finally, Eskridge does not explain why we should view unmarried, non-monogamous (and even promiscuous) males as "uncivilized."

139. See id. at 84. Specifically, Eskridge argues that the outcome of Bottoms v Bottoms, 444 S.E.2d 276 (Va. Ct. App. 1994), rev'd, 457 S.E.2d 102 (Va 1995), might have differed if Virginia recognized same-sex marriages. In the Bottoms case, Sharon Bottoms, a working-class lesbian, lost custody of her child after the court granted a custody petition brought by Kay Bottoms-Sharon Bottoms' mother.

The decisions in Bottoms are replete with gender and class hostility and homophobia. For a more extensive analysis of this point see Stephen B. Pershing, "Entreat Rfe Not 10 Leave Thee": Bottoms v. Bottoms and the Custady Rights of Gay and Lesblan Parents, 3 WM. \& MARY BuL RTS. J. 289 (1994); Amy D. Ronner, Bottoms v. Bottoms: The Lesblan hother and the Judicial Perpetuation of Damaging Stereotypes, 7 YAlE J.L. \& FeanisM 341 (1995). For a general discussion of the difficulties gays and lesblans fece in custody battles due to judicial bias, see Julie Shapiro, Custady and Conduct: How the Law Falls Lesbian ard Gay Parents and Their Children, 71 IND. LJ. 623 (1996). The trial judge, for example, based the ariard of custody to Kay Bottoms on the following:

Sharon Bottoms has admitted that she is living in an homosexual relationship. She is sharing her bed with her female lover. Examples given were kissing, patting, all of this in the presence of the child .... I will tell you first that the mother's conduct is illegal. I will tell you that it is the opinion of the court that her conduct is immoral. And it is the opinion of this court that the conduct of Sharon Bottoms renders her an unfit parent.

Bottoms, 444 S.E2d at 279 (quoting ruling of the trial court) (numerous ellipses omitted). Sharon Bottoms appealed, and the appellate court reversed the decision, finding that "[t]he fact that a parent is homosexual does not per se render a parent unfit to have custody of his or her child." Id. at 281 (citing Doe v. Doe, 284 S.E2d 799, 806 (Va. 1981)).

Kay Bottoms appealed to the Supreme Court of Virginis, which reversed the appellate decision and remanded the case for the trial court to reinstate the order of custody. See Botoms, 457 S.E.2d at 102. The court's "reasoning" reinforees, and is informed by, class, gender, and sexual biases. The court declared Sharon Bottoms unworthy of custody because it found that she

moves her residence from place to place, relying on others for support, and uses welfare funds to "do" her fingernails before buying food for the child. She has participated in illicil relationships with numerous men, aequiring a disease from one, and "sleeping" with men in the same room where the child's crib was located.

Id. at 108. The court also reasoned that "active lesbianism preticed in the home may impose a burden upon a child by reason of the 'social condemnation' attached to such an armengement . . . Id. (citing Roe v. Roe, 324 S.E.2d 691, 694 (Va 1985)).

Eskridge correctly notes that the Bottoms case reflects judicial homophobia. ESKRIDGE, THE CASE FOR SAME-SEX MARRIAGE, supra note 106, at 84. Eskridge, however, argues that "most judges would still have been reluetant to terminate marred parental custody. Sharon was vulnerable because she was lesbian and working-class and unmarried." Id (emphasis in origina). Eskridge therefore concludes that legal "recognition for same-sex marriages rould have insulating ripple effects for working-class lesbians like Sharon Bottoms." Id

Eskridges conclusion places too much importance on marital status mether then interwoven class, gender and sexual subordination. Eskridge's "argument rests on the assumption that possession of a marriage certificate will legitimize the [lesbian or gay] sexual relationship . . . so that the judge will not consider the ... relationship . . . a threat to the 'best inlerests of the 
lawyer and former Executive Director of Lambda Legal Defense and Education Fund (a gay and lesbian civil rights organization), "would like to see the [same-sex marriage] issue rise to the top of the agenda of every gay organization .....140 Stoddard believes that "marriage is ... the political issue that most fully tests the dedication of people who are not gay to full equality for gay people, and also the issue most likely to lead ultimately to a world free from discrimination against lesbians and gay men."141 Similarly, Evan Wolfson, a senior attorney at Lambda, argues that Baehr v. Lewin is "the most important gay rights victory that we have ever had ...."142 Wolfson contends

children' . . . Duclos, supra note 109, at 55-56 (challenging assumption that marriage will aid gays and lesbians in custody disputes). Marriage will likely have little impact on homophobia in gay and lesbian custody cases. See id. at 56 " "The history of judicial treatment of same-sex relationships in the custody context constitutes such appalling evidence of deep-seated and visceral anti-lesbian and anti-gay feeling ... that it seems naive to think such attitudes can be wiped out by a marriage certificate."). Even if marriage will blunt homophobla, it will not diminish the gender, class and racial subordination issues that also arise in gay and lesbian custody cases.

140. Stoddard, supra note 109 , at 400 .

141. Id. (emphasis in original).

142. Maria De La O, Profile: Evan Wolfson; The Fight for Same-Sex Marriage, 21 HUM. RTS. 22 (1994) (emphasis added). In Baehr v. Lewin, 852 P.2d 44 (Haw. 1993), the Hawail Supreme Court ruled that Hawaii's prohibition of same-sex marriage constitutes unlawful gender discrimination, subject to strict scrutiny, under Hawaii's constitution. The court remanded the case to the trial court for the state to offer a compelling interest for its policy. Id. During the completion of this Article, the trial court held, on remand, after a bench trial, that the state had failed to offer a compelling interest for the policy. This decision has been stayed pending an appeal by the state. See Baehr v. Miike Civ. No. 91-1394, 1996 WL 694235 (Haw. Cir. Ct.) (1996).

Since the decision in Baehr, gay and lesbian legal theorists, political activists, and other commentators have engaged in extensive debates over whether the full faith and credit clause should compel other states to recognize same-sex marriages that may occur in Hawail (if the courts ultimately reject the state's "compelling" reasons for prohibiting same-sex marriage). See, e.g., Cordell, supra note 109; Cox, supra note 109; d'Amato, supra note 109; Keane, supra note 109; Sage, supra note 109. The enormous attention paid this issue by gay and lesbian theorists underscores the class differences that exist among gays and lesbians and the class assumptions that underlie pro-same-sex marriage arguments. Only individuals with ample economic resources could leave their homes, travel to Hawaii for a wedding (and perhaps honeymoon), and return to their resident state to battle legal authorities for recognition of their marriages. As a further indication of the class-based assumptions that inform the same-sex marriage issue, Professor Jennifer Gerrarda Brown has argued that same-sex maniage could become an economic "cash cow"-due to the formation of gay and lesbian matrimonial markets-in states that give it legal recognition. Brown, supra note 109 . Brown concedes that her argument is subject to the criticism that "it assumes wealth among gay men and lesbians. This seems to leave out poorer people, or at least conditions the right of marriage upon a couple's ability to travel." Id. at 748 n.10. Brown reasons however, that economically disadvantaged gays and lesbians "might take solace from the hope that" a greater number of states will legalize same-sex marriage once they discover the economic benefits reaped by "first-mov- 
that the Baehr decision "shifted the very ground underlying gay people's second-class status, and one of the, if not the major, barriers to our full and equal citizenship has cracked wide open."143 Wolfson also believes that "marriage is the central legal and social issue of our society."144

Perhaps the most extreme example of the emphasis placed on samesex marriage comes from Andrew Sullivan, a conservative gay writer and former Editor-in-Chief of the New Republic. In his recently released book, Virtually Normal, Sullivan argues that same-sex marriage should be the "centerpiece" of a "new gay politics" 45 - a narrow politics limited only to combatting "state" discrimination against "homosexuals." Sullivan believes that "denying [marriage] to homosexuals is the most public affront possible to their public dignity."147 Sullivan thus places the utmost reliance upon legal marriage as an instrument of sexual freedom and equality. He contends that

[g]ay marriage . . . is the first step in any resolution of the homosexual question ... . If nothing else were done at all, and gay marriage were legalized, ninety percent of the political

er" states. Id. Although poor gays and lesbians can probably wait for marringe to spread across the mainland, they would likely derive greater benefit from direet policies aimed at improving their economic situalions.

Congress has responded to the Hawail litigation by enacting the "Defense of Manriage Act" See Defense of Marriage Act, Pub. L. No. 104-199, 110 Stat, 2419 (1996). The legislation adopts a federal, opposite-sex definition of marriage. Id. The legislation also purports to grant states permission to decline recognition of same-sex marriages performed in other stales. Id. Several states have also moved to adopt opposite-sex marital statutes. See Eric Schmith, Senators Reject Both Job-Bias Ban and Gay Marriage, N.Y. Tumes, Sept. 10, 1996, at Al.

143. Wolfson, supra note 109, at 581 (emphasis added).

144. Joseph Hanania, The Debate Over Gay Marrioges: No Unity, LA. TMIES, June 13, 1996, at El (emphasis added).

145. ARDREW SULLIVAN, VIRTUALLY NORMLAL: AN ARGRENT ABOUT HOMOSENUALTT 178 (1995).

146. Id. at 169-87. Sullivan's emphosis on fighting "state" discrimination stems from his adherence to traditional liberalism and its opposition to state interference with "individual" liberty and "private" affairs. See id. at 171 ("I]t is the only polities that . . . fully respects liberalism's public-private distinction ...."). This position, hoviever, directly confliets with Sullivan's vigorous support of marriage (both same- and opposite-sex), because by recognizing marriage, the state attaches certain duties and economic incentives to traditionally "privale" relationships. See EsKRIDGE, The CASE FOR SAME-SEX MARRIAGE, supra note 106, at 66-72 (discussing state-imposed duties and benefits of mantiage). See also Bradley P. Smilh, No, I'll Calegorize You, 105 YALE LJ. 2025, 2030 (1996) (noting Sullivan's conflicting positions and anguing that "[g]overnment recognition of any marriage is an inherently nonneutral ect, as it encounges binary, exclusive coupling through a variety of economic incentives. Marriage also infuses a variety of public rights and duties into the most private of human relationships.").

147. SuLLivan, supre note 145, at 179 (emphasis added). 
work necessary to achieve gay and lesbian equality would have been achieved. It is ultimately the only reform that truly matters. $^{148}$

Only those individuals buffered from racial, class, and gender oppression and who, but for their (homo)sexual orientation are "virtually normal," could reasonably expect as narrow a reform as legal marriage to bring them almost complete ("ninety percent") equality and liberation. Women, men of color, and the economically disadvantaged (including many white gay men) need much broader and deeper social change to improve their lives. ${ }^{149}$ Thus, the disparate responses of white men, women, and gay men of color to the same-sex marriage movement likely evidence that they are unequally affected by social power and, therefore, would benefit differently-if at all-from state recognition of their relationships. ${ }^{150}$

Ultimately, however, the true issue for legal scholars and civil rights attorneys involyed in the same-sex marriage debates is not whether some gays and lesbians of color (or white lesbians or the poor) desire marriage. These populations are large and diverse. Some of these individuals will find marriage important; ${ }^{151}$ others will not. Rath-

148. Id. at 185 (emphasis added).

149. See Smith, supra note 146, at 2029 (arguing that Sullivan's disapproval of political and legal challenges to "private" discrimination against gays and lesbians is "pragmatically questionable" and unprincipled).

150. Eskridge's own explanation for the recent explosion of interest in same-sex marriage among gays and lesbians actually confims the anti-essentialist concern that marriage is driven by white, upper-class interests. Eskridge attributes the marriage movement, in part, to the following 1980 s demographic pattems:

The "queer boomers" were aging, making more money than love, and settling down with partmers. The guppie (gay urban professional) with a partner and a Porsche was replacing the free love advocate with a placard and a toke. The new Generation Xers were open to the diverse sexuality offered by gay liberation but more skeptical of its early bam-burning radicalism.

ESKRIDGE, THE CASE FOR SAME-SEX MARRIAGE, supra note 106, at 58. Clearly, marginalized segments of the gay and lesbian community do not reside within this exclusive, Porsche-owning, urban, professional, marriage-seeking community.

151. In fact, despite their general ambivalence toward the issue, several people of color-both gay and heterosexual-have voiced support for same-sex marriage. Michelle Garcia, Altered States: Same-Sex Marriage and Civil Rights, ETHNIC NewsWATCH, Apr. 30, 1996, at 16 (describing support for marriage among gays and lesbians of color); Deb Price, Japanese-American Group Backs Gay Marriages, STAR TRIB., Oct. 5, 1994 (reporting support for same-sex marriage by the Japanese American Citizens League, a racial civil rights organization); Liz Spayd \& Brigid Quinn, The Gay Marriage Trap: We Fell Into a Right-Wing Ambush, WASH. POST, June 16,1996 , at $\mathrm{Cl}$ (noting that black gay activist Keith Boykin supports same-sex marriage, though critical of its priority in gay and lesbian politics and of the movement's political strate- 
er, gay and lesbian legal theorists, given the multidimensional nature of heterosexism, must continue to problematize and rethink grand claims that gay and lesbian marriages will "undermine social homophobia," place gays and lesbians into "society's mainstream," eliminate "insideroutsider issues," and "fully test" society's commitment to complete equality for gays and lesbians. They certainly need to question the troubling assertion that same-sex marriage is "the only reform that truly matters." When we consider race, class, and gender inequality-and the virulence of homophobia-these lofty claims tumble, regardless of the interest individual gays and lesbians of color may have in marriage. Venus Xtravaganza, for example, wanted desperately to marry. ${ }^{152}$ Marriage alone, however, would likely have provided her few-if any-material benefits" ${ }^{153}$ and surely would not have thrust her into "society's mainstream"- due precisely to the persistence of racism, poverty, and hostility toward transgendered people. ${ }^{154}$ Thus, racial, class, and gender

gies). Also, people of color have brought legal challenges to prohibitions of same-sex marriage. See ESKRIDGE, THE CASE FOR SAME-SEx MARPLAGE, supra nole 106, at 55-56 (discussing "first" black lesbian couple to bring suit challenging same-sex marringe prohibition); Carcy Goldberg, Couple Who Stirred Issue of Same-Sex Mamlage Silll Hopeful, N.Y. ThIES, July 28, 1996, § 1, at 12 (reporting that Patrick Lagon, a Baehr litigart, is of Filipino descent); Fem Shen, A Same-Sex Couple Married to the Cause: H'omen Entbrace Natlonal Fight They Helped Spur Over Wedlock, WASH. POST, Sept. 10, 1996, at Al (reporting that Genor Dancel, a Baehr litigant, is of Hawaiian descent).

152. HEMPHLL, supra note 54 , at 118.

153. Eskridge and other proponents of gay and lesbian marriage argue that married couples may take advantage of an array of economic and other preferences including inheritance and tax law benefits and health insurance coverage from their partners' employers. See, e.g., ESKRIDGE, THE CASE FOR SAIE-SEX MARRIAGE, supra note 106, at 66-70; Mohr, supra note 109, at 227; Stoddard, supra note 109, at 399-400. Many of these benefits, however, will primarily affect employed and economically privileged individuals, not the poor. See Colker, supra note 109 , at 325 (discussing unequal class distribution of marriage's economic benefits); Duclos, supra note 109, at 52-55 (same); Ettelbrick; supra note 108, at $402-05$ (5ame); Robson, supra note 12, at 182 ("Marriage will not be an advantage for lesbians in all classes. The very availability of marriage could economically disadvantage lesbians receiving public entitlements because the state imputes the income of one 'partner' to the other, thus disqualifying a partner who might otherwise be eligible for "welfare' benefits."). Furthermore, legal scholars have failed to explain why the state should deny unmarried gays and lesbians (and heterosexuals) these benefits. See Colker, supra note 109, at 324 ("It makes more sense to change institutions so that their benefits are not marriage dependant rather than make lesbian and gay people eligible for those benefits only by getting married."); Polikoff, supra note 108, al 1549 ("Ia]dvocating lesbian and gay marriage will detract from, even contradich, efrorts to unhook economic benefits from marriage and make basic health care and other necessities available to all").

154. Venus' desire for marriage, wealth, and white female status actually affirms-not chyllenges-racial, gender, and class hierarchy. See HenpHLL, supra note 54, at 116 (the longing to be white, wealthy, and female reflects a desire to be "in collusion with white supremacy"); 
inequities destabilize essentialist claims regarding the potential "mainstreaming" effects of same-sex marriage-regardless of whether individual people of color wish to pursue it.

Despite his essentialism, Eskridge actually concedes that "[t]he legitimate concern of the new insiders argument is that prejudice is multilayered and synergistic in America."155 $\mathrm{He}$, nevertheless, fails to contend with-and dismisses-the reality of mulitidensional oppression because "the availability or nonavailability of same-sex marriage does not affect that reality. The gay man on average is still in a better position, whether he can get married or not."156 Thus, Eskridge acknowledges the existence of a privileged "gay man." This gay man, however, seemingly represents the positionality of all gay men-his experiences reflect "the" gay male experience. Eskridge also dismisses the factors-race, class, and gender hierarchies-that create this man of privilege. As Eskridge states,

[t]he gay man is less likely to commit himself to gender and race discrimination issues than is the lesbian or the person of color, again whether or not he can get married. The gay man is already more likely to be an insider. Allowing him to marry another man will not change that. ${ }^{157}$

Eskridge's gay man, who is- "more likely"-an insider apathetic toward issues of race and gender inequity, is also "likely" white and economically privileged.

Ironically, Eskridge implies that feminist critics should cease challenging efforts to allow "the gay man" to marry because he will not, after all, develop a strong commitment to "gender . . . discrimination issues" and will retain his "better position," "whether or not he can get married." At the same time, however, Eskridge strenuously argues that because the denial of same-sex marriage precludes "the gay man" from marrying another man-an act a woman could do-and affirms pernicious gender-role stereotypes and hierarchies, it is a form of invidious sex discrimination under the Constitution. ${ }^{158}$ Eskridge neglects to ex-

HoOKs, supra note 57 , at 148 ("mf the class, race, and gender aspirations expressed by tho drag queens . . . is always the longing to be in the position of the ruling-class woman then . .. there is also the desire to act in partnership with the ruling-class white male . . . . This combination of class and race longing that privileges the 'femininity' of the ruling-class white woman, adored and kept, shrouded in luxury, does not imply a critique of patriarchy.").

155. Eskridge, A History of Same-Sex Marriage, supra note 106, at 1492 (emphasis added).

156. Id. at 1492-93.

157. Id. at 1493.

158. See ESKRIDGE, THE CASE FOR SAME-SEX MARRIAGE, supra note 106, at 162-72; Eskridge, $A$ 
plain why "the gay man's" gender discrimination claim should have priority over several lesbians' claims that marriage, as an institution, oppresses them "as women"-particularly when "the gay man," as Eskridge states, has no interest in "gender discrimination issues" and will maintain "his" patriarchal privilege under marriage.

Eskridge then advances legal arguments for same-sex marriage although, as he concedes, it will neither affect the reality of multilayered oppression nor change the forces that make "the gay man" an insider. ${ }^{159}$ If gay marriage does not challenge racial, class, and gender inequality, then we should-in light of the "multilayered and synergistic" nature of sexual subordination-continue to question its high priority, ${ }^{160}$ and even legitimacy, as an instrument of gay and lesbian liberation. At a minimum, we should examine-given the adverse impact poverty may have on the level of benefits and attractiveness of marriage-what other legal and policy reforms must occur in order to make marriage and family life accessible to and meaningful for poor gays and lesbians.

History of Same-Sex Marrioge, supra note 106, at 1510. The Baekr court also applied this reasoning. See Baehr, 852 P.2d at 44. Furthermore, several commentators have extensively developed the theory, in same-sex marriage and other contexts, that discrimination against lesbians and gay men is sex discrimination. See, e.g., Andrew Koppelman, The Mflsegenalion Analogy: Sodomy Law as Sex Discriminallon, 98 Yale LJ. 145 (1988) Thereinafter The Miscegenation Analogy]; Andrew Koppelman, Why Discriminatlon Against Lesbians and Gay Men Is Sex Discrimination, 69 N.Y.U. L. REV. 197 (1994); Sylvia A Law, Homosersaliby and the Social Meaning of Gender, 1988 Wis. L Rev. 187; Francisco Valdes, Queers, Sissles, Dykes, and Tomboys: Deconstructing the Conflation of "Ser," "Gender," and "Sexual Orientafion" in Euro-American Law and Socieby, 83 CAL. L. REV. 1 (1995); I. Bennett Capers, Note, Sex(tual Orientation) and Title VII, 91 COLUM. L. REV. 1158 (1991). These scholars argue that sexual orientation discrimination is "sex" discrimination because it prohibits a roman, for example, from engaging in an activity (e.g. marriage to a vioman) in which a man could lawfully engage. This reasoning often extends, by analogy, the Supreme Court's ruling in Lowing : $h i r$ ginia, 388 U.S. I (1967), which found antimiscegenation statutes unconstitutional on the grounds that they prohibit blacks, for example, from marying whiles-something a while person could Iawfully do-and that they reinforee white supremacy. For a more extensive discussion of this analogy, see Koppelman, The Anscegenation Aralogy, supra. See also Es:RuDGe, THE CASE FOR SAME-SEX MARRIAGE, supra, at 153-63.

159. See Eskridge, A History of Same-Sex Marrlage, supra note 106, at 1492-93.

160. See Colker, supra note 109, at 326 ("I would not encourage the lesbian and gay community to make [same-sex marriage] legislation a high priority item."); Dunlap, supra note 132, at A12 (reporting view of black lesbian activist that health and anti-violence issues are "more fundamental to [gay and lesbian] survival"); Hanania, supra note 144, at El (same-sex mariage issue is "diverting limited resources and energies from other priorities desperntely in need of tending") (quoting Martin Duberman, a gay historien and Director of the Center for Gay and Lesbian Studies at City University of New York); Spayd \& Quinn, supra note 151, at Cl (gays and lesbians should "focus on rights fundamental to the gay movement's survival, like combating workplace discrimination, AIDS and reproductive cancers, whose incidence is partieularly high among lesbians"). 
Because he fails to consider, and even dismisses, the fact that racial and economic subordination affect gay and lesbian experience, ${ }^{161}$ Eskridge overstates the value of legalized same-sex marriage as an instrument of social transformation and equality for all gay and lesbian people and nullifies the diverse cultural practices and experiences of people of color and the poor.

\section{Focusing on "Commonality"}

a. "Common," "Essentializing," and "Monolithic" Assumptions

In addition to rejecting the importance of racial and class privilege and subordination in gay and lesbian lives, gay and lesbian legal theorists also marginalize racial and class differences by attempting to articulate "common" experiences of or assumptions about all gay and lesbian people. These common experiences and assumptions, however, may obscure the realities of people of color and the poor. For example, Marc Fajer, in a provocative analysis, endeavors to "re-tell" personal narratives of gay and lesbian people in order to "counter and demonstrate" homophobic stereotypes. ${ }^{162}$ Fajer compellingly argues, as have other commentators, that these negative stereotypes affect judicial decisionmaking in cases involving questions of gay and lesbian equality and that their deconstruction is, therefore, an important task for legal scholars and civil rights attorneys. ${ }^{163}$ To begin the important project of countering negative gay and lesbian constructs, Fajer borrows the "storytelling" technique from critical race scholars such as Richard Delgado $^{164}$ and Mari Matsuda. ${ }^{165}$ Fajer notes that his attraction to this

161. It is in his legal arguments for same-sex marriage that Eskrioge analyzes racial subordination. Race enters his analysis, however, only by analogy. ESKRJDGE, THE CASE FOR SAMESEX MARRIAGE, supra note 106, at 153-63. Eskridge likens bans on same-sex marriage to antimiscegenation statutes, declared unconstitutional on Equal Protection grounds in Loving, 388 U.S. at 1. Eskridge claims that both racial and gender exclusions in marriage perpetuate harmful social hierarchies. Eskridge develops this reasoning from arguments Koppelman makes in the sodomy context. See generally Koppelman, The Miscegenation Analogy, supra note 158.

Eskridge's racial analogy treats race and sexual orientation as unconnected and unrelated identities. Eskridge's distancing of race from sexuality through analogy, however, does not diminish the importance of race and class in gay and lesbian lives or in his analysis. Rather, by neglecting to interrogate issues of racial and economic subordination, Eskridge advances arguments, e.g., that same-sex marriage will eradicate "insider-outsider" issues, based on racial and class privilege.

162. Marc A. Fajer, Can Two Real Men Eat Quiche Together?: Storytelling, Gender-Role Stereotypes, and Legal Protection for Lesbians and Gay Men, 46 U. MLAMI L. REV. 511, 515 (1992).

163. See generally id.

164. See Richard Delgado, Storytelling for Oppositionists and Others: A Plea for Narrative, 
jurisprudential method stems from its powerful ability to offer "new perspectives" into legal discourse. ${ }^{166}$ Fajer's analysis introduces to legal theory an important dialogue, grounded on "gay and lesbian" experiences, regarding issues of sexual subordination. His analysis, however, could have benefitted from some consideration of the racial and class complexity of homophobic stereotypes and the impact this complexity has upon people of color.

As an initial matter, Fajer does not discuss the racial backgrounds of the individuals whose stories he re-tells. This omission implies a unitary gay experience, one unaffected by racial differences. ${ }^{167}$ Fajer's omission of race also directly impacts his analysis. For example, Fajer characterizes "coming out"-or the "process of telling other people we are gay"168 -as "perhaps the central events in gay lives today."169 Such a characterization blurs race and class differences. Because race- and class-subordinate individuals are burdened by multiple forms of social and economic exclusion, they can likely point to other, perhaps more "central" and "traumatic"170 experiences in their "gay lives"-such as racial discrimination and economic deprivation. ${ }^{171}$

Fajer also argues that coming out is "liberating and emotionally helpful"172 and that "concealment" of one's gay identity, on the other hand, "interferes with the creation and cohesion of a gay community."173 The coming out process, however, does not necessarily or automatically "liberate" people of color, who, by revealing their sexual orientation and attempting to integrate themselves within white gay and lesbian communities, may encounter racial hierarchy. Thus, racial hierarchy prevents the formation of a "cohesive" gay community-even

87 MICH. L. REV. 2411 (1989).

165. See Mari J. Matsuda, Looking to the Bottom: Crilical Legal Studles and Reparations, 22 HARV. C.R-C.L. L. REV. 323 (1987).

166. See Fajer, supra note 162, at 517. Fajer argues that "[s]lories from previously excluded voices enrich our understanding of how the law operates and suggest new approzches to many legal issues." Id. at 519 (citations omitted).

167. See Rosenblum, supra note 12, at 88 (10 label "parties in [litigation) as lesbian or gay without specifying other aspects of their social position implies that they occupy a universal position. The effect of these false universals is to erase other queers and to ignore their very different experiences.").

168. Fajer, supra note 162 , at 520 .

169. Id (emphasis added).

170. See id.

171. See sources cited supra note 116 (describing sexual orientation as an additional burden for gays and lesbians of color).

172. Fajer, supra note 162 , at 596 (citation omitted).

173. Id. at 598 . 
among those gays and lesbians who do not "conceal" their sexual orientation. Marlon Riggs' experiences with racism in the predominately white San Francisco gay and lesbian community demonstrate this aspect of the coming out process. South Asian gays and lesbians have also documented the racial and cultural marginalization they encounter in gay and lesbian communities:

Once some of us entered the lesbian and gay subculture of the West, our feeling of isolation did not fade as we had assumed it would; it only changed face . . . None of our newly found gay or lesbian friends and acquaintances spoke our languages, shared our history, or really understood our culture. ${ }^{174}$

These comments expose a fundamental weakness in the formation of "gay" and "lesbian" communities. As lesbians of color have observed in the context of lesbian separatism, these communities coalesce around the singular issue of sexual identity, thereby denying racial and class inequality and cultural differences. ${ }^{175}$ A narrow portrayal of the coming out process similarly blurs the racial complexity of sexual identity. ${ }^{176}$

Fajer's tendency to emphasize the experiences of class-privileged individuals is further illustrated by his discussion of "romantic images and symbols" invoked by gays and lesbians to describe their relationships. ${ }^{177}$ Seeking to demonstrate the "long-term" and monogamous nature of gay and lesbian romances, Fajer lists, among other items, "candlelight dinners, flowers, and Niagara Falls" as symbols of "love"

174. Introduction to LOTUS OF ANOTHER COLOR, supra note 9, at 12. See also id. at 14 (The gay and lesbian "subculture does not acknowledge that South Asians and other ethnically distinct groups have a different life experience, different societal and familial influences, and different needs . . ...").

175. See, e.g., Combahee River Collective, A Black Feminist Statement, in THIS BRIDGE CALLED MY BACK, supra note 1, at 214 (questioning "whether lesbian separatism is an adequate and progressive political analysis and strategy, even for those who practice it, since it so completely denies any but the sexual sources of women's oppression, negating the facts of race and class"); Smith \& Smith, supra note 105, at 120-23 (discussing racial and class csscntialism of lesbian separatism). See also PFELEN, IDENTIYY POLmCS, supra note 105, at 161-66 (discussing racial and class critiques of lesbian separatism).

176. Compare Introduction to A LOTUS OF ANOTHER COLOR, supra note 9, at 12, 14 (discussing marginalization of South Asians within larger gay and lesbian community) with Gregory J. Herek, Myths About Sexual Orientation: A Lawyer's Guide to Social Science Research, 1 LAW \& SEXUALITY 133, 145-46 (1991) (asserting that "Iesbians and gay men probably maintain self esteem most effectively when they identify with and are integrated into the larger lesbian and gay community.").

177. See Fajer, supra note 162 , at 552 . 
in gay and lesbian relationships. ${ }^{178} \mathrm{He}$ also re-tells the story of one "male couple [that] returned to Europe to find the place they had [first] met ...."179 Such images subtly unveil the existence of economic privilege among gays and lesbians by portraying the notion of "romance" in middle and upper-class terms. Fajer's conclusion that "[t]he prohibition of gay marriage may be the most significant form of discrimination against gay couples,"180 may also reflect a presumption of racial and class privilege in gay and lesbian relationships. ${ }^{181}$

The "exploitation" of economic privilege in the gay and lesbian community has had a significant, negative effect on gay and lesbian legal and political reform efforts and on heterosexual society's perceptions of gays and lesbians. Several surveys have fostered the development of a stereotype that "all" gay men and lesbians are wealthy-relative to the "heterosexual" population. ${ }^{182}$ These surveys are based on data compiled from reading lists of gay and lesbian magazines, mailing lists of gay and lesbian political organizations, and polls of persons attending gay and lesbian cultural events. ${ }^{183}$ Gay and lesbian magazines have "exploited" these surveys in order to solicit corporate advertisements. ${ }^{184}$ Anti-gay and lesbian groups, however, have appropriated the surveys-in order to depict the gay and lesbian community as wealthy and privileged and, therefore, undeserving of civil rights protection. ${ }^{185}$

178. Id.

179. Id. at 553.

180. Id. at 577 (emphasis added).

181. See supra pp. 589-602. Even if middle- and upper-class romantic ideals were desired by poor people of color, the result would not be unproblematic. The linkage of personal satisfaction and self-worth with upper-class status has led to consumerism and nihilism annong the poor of color. See CORNELL WEST, RACE MATtERS 17-31 (1993). Indeed, the desire to echieve upper-class status proved detrimental for both Rivera and Yenus Xtravagarze. See supra pp. 572-73 (describing Rivera's fatal quest to escape poverty); Hearkul, supra note 54, at 118 (noting Venus' desire to have a "car" and "nice home" in "Peekskill" or "Florids" among other things; describing how attempt to actualize this desire helps create circumstances surrounding her murder).

182. See, e.g., Samuel A Marcosson, The "Special Rights" Caraard in the Debate Orar Lesbian and Gay Rights, 9 NOTRE DARE J.L. ETHICS \& PUB. POL'Y 137, 160 n.69 (1995) (discussing studies apparently indicating gay wealth); Margaret M. Russell, Lesblan, Gaj and Bisexual Rights and "The Civil Rights Agenda," 1 AFR. AN. L. \& POL'Y REP. 33, 45 \& n.48 (1994) (discussing use of data apparently indicating gay wealth to bolster anti-gay politieal agendas); Karen De Witt, Gay Presence Leads Reviral of Declining Nelghborhoods, N.Y. TMES, Sept 6, 1994, at Al4 (discussing "notion that all homosexuals are rich"); Stuart Ellioth, A Shorper hiew of Gay Consumers, N.Y. TmEs, June 9, 1994, at DI ("it has become conventional wisdom to consider homosexuals far more affluent than the general population").

183. See VAID, supra note 9, at 252-53.

184. See id. at 252.

185. See id. at 250-52. See generally, Schacter, supra note 104, at 291-94. Pcrhaps the 
These surveys, however, overstate gay and lesbian income levels. First, the poor are less likely than the wealthy to hold magazine subscriptions $^{186}$ or to join mailing lists of political organizations (a step typically taken after making a financial contribution to the organizations). Consequently, the surveys tend to exclude the poor and, therefore, produce a biased sample of gays and lesbians. Furthermore, as Samuel Marcosson observes,

[t]he lesbians and gay men most apt to respond to such surveys

most damaging use of these surveys was by the organization "Colorado for Family Values" during the campaign to pass "Amendment 2" to the Colorado constitution. Amendment 2, which passed on November 3, 1992, prohibited the state and its subdivisions from enacting legislation or regulations which give gays and lesbians a "protected status or claim of discrimination." Evans v. Romer, 882 P.2d 1335, 1338 (Colo. 1994), affd sub nom, Romer v. Evans, 116 S. Ct. 1620 (1996). The Supreme Coust subsequently declared Amendment 2 unconstitutional, reasoning that it targeted homosexuals for discrimination and lacked a rational relationship to a legitimate governmental purpose, in violation of the Equal Protection Clause of the Fourteenth Amendment. See Evans, 116 S.Ct at 1620. The Supreme Court invalidated the amendment on different grounds than the Colorado Supreme Court. The latter court found that the amendment violated the "fundamanetal righ" of gays and lesbians to participate in the political process. See Evans, 882 P.2d at 1335.

To help garner political support for Amendment 2, Colorado for Family Valucs distributed highly effective literature which asked "[a]re homosexuals 'disadvantaged' economically? You decide! Records show that even now, not only are gays not economically disadvantaged, they'se actually one of the most affluent groups in America!" VAID, supra note 9, at 252 (quoting organization's literature). See also Schacter, supra note 104, at 292 (reporting organization's view that "militant gays would create a whole new protected class of affluent, well-educated, sexually deviant political power brokers. The true meaning of civil rights would never be the same.") (citing Will Perkins, Views on Gay Rights Conflict, DENVER POST, Oct. 11, 1992, at ID (opinion letter authored by the Executive Chairman of the Board of Colorado for Family Values)).

This position has also been advanced in legal scholarship. Richard F. Duncan, for example, attempts to distinguish discrimination against "racial and ethnic minorities" from discrimination against "homosexuals." Relying on the gay wealth studies, Duncan argues that "the available evidence indicates that [discrimination against homosexuals] is nether pervasive nor economically devastating. Not only are homosexuals an affluent and a highly educated class, they are also politically powerful." Richard F. Duncan, Who Wants to Stop the Church: Homosexual Rights Legislation, Public Policy, and Religious Freedom, 69 NOTRE DAME L. REv. 393, 409 (1994). Justice Scalia's dissent in Evans, in which Chief Justice Renquist and Justice Thomas join, also portrays gays and lesbians as disproportionately wealthy and powerful and, therefore, undeserving of even rational basis protection. See Evans, 116 S.Ct. at 1634 ("[T]hose who engage in homosexual conduct tend to ... have high disposable income ... [and] they posess political power much greater than their numbers."). Justice Scalia characterizes Amendment 2 as an "unimpeachable," "modest attempt by seemingly tolerant Coloradans to preservo traditional sexual mores against the efforts of a politically powerful minority to revise those mores through the use of the laws." Id. at 1629.

186. See VAID, supra note 9, at 254 (citing study finding income levels of periodical subscribers exceed national average). 
are those who are in a position of relative comfort and security, and not those in a position of relative economic insecurity, for whom the loss of their job or home if their sexual orientation became known would be most catastrophic. If relatively poor gay men and lesbians are less willing to state their sexual orientation in response to surveys, or simply do not participate in them, the results will overstate the affluence of the overall gay community. ${ }^{187}$

Therefore, even if the poor have access to such surveys, they are less likely than the wealthy to reveal their sexual orientation. Thus, Marcosson's critique suggests a positive relationship between wealth and the ability to come out-or to identify oneself publicly as "lesbian" or "gay." 188

Researchers are attempting to conduct studies that conect the sampling bias of the earlier surveys and that more accurately portray the economic condition of gay and lesbian people. One recent survey, controlling for gender, has found "little noticeable difference" between gay and heterosexual incomes. ${ }^{189}$ In addition, a University of Maryland researcher has conducted a survey that focuses on the participants' "sexual behavior" as opposed to requiring participants to identify themselves as "gay" or "lesbian." This study finds that the incomes of "behaviorally" gay and lesbian individuals are lower than their heterosexual counterparts-when education, occupation, and gender factors are controlled. ${ }^{190}$

The connection between economic security and the opportunity to lead an openly gay or lesbian lifestyle means that gays and lesbians of color, who are disproportionately poor, will face greater obstacles com-

187. Marcosson, supra note 182, at 160 n.69 (citing Gay' Horkers Eam Less in Same Job, University of Maryland Study Finds, Daily Lab. Rep. (BNA) No. 156, at A9 (Aug. 16, 1994)). See also De Witt, supra note 182, at A14 (assumption of gay riealth "based on market research that had focused on white, high-income homosexuals") (quoting conductor of suricy that found gay and lesbian incomes less than heterosexual incomes); Ellioh supra note 182, at D1 (controlling for gender, study found "little noticeable difference" in incomes of gays, lesbians and heterosexuals); Russell, supra note 182 , at 45 n.48.

188. Cf. VAID, supra note 9, at 256 ("middle-class and tiealthy gay people are far mose likeIy to be visible than are wotking-class and poor queers").

189. Elliot, supra note 182 , at D1.

190. VAID, supra note 9, at 255 (citing M.V. Lee Badgett, Economic Evidence of Sexual Orientation Discrimination (Nov. 1993) (unpublished manuscript)); Marcosson, supra note 182, at 160-61. Additional surveys are required to determine the full impact of class on sexual orientation discrimination and vice yersa. 
ing out. Indeed, gays and lesbians of color have stated that racial, gender, and class oppression force them to conceal their sexual orientation because they fear the "horrible risk ... [ [of] further disenfranchise[ment]."191 Their testimony underscores the need for multidimensional gay and lesbian liberation theory and political action. Moreover, because the notion of gay and lesbian wealth renders appeals for "gay rights" hollow in some circles, gay and lesbian legal theorists must be careful not to affirm-and must make it a priority to deconstruct-this perception in their work. ${ }^{122}$ Furthermore, because the "gay and lesbian" wealth stereotype evolves from race- and class-biased statistics-statistics that are often contrasted with the low-income levels of the presumedly distinct population of "people of color" subtly reflect society's views of white gays and lesbians or a perception that all gays and lesbians are white. In either event, gay and lesbian legal scholars must analyze and discuss both racism and poverty, and how these forces constrain one's ability to "come out," in order to challenge effectively this harmful construct.

In addition to discussing gay and lesbian romance, Fajer attempts to support his argument that gays and lesbians form long-term relationships by stating that "in the last several years, gay male sexual practices have altered dramatically as more accurate information about the transmission of HIV has become available."194 This statement ignores the experiences of many gay and bisexual men of color, who have persistently lacked access to effective sources of ADS prevention information (particularly during the early history of the epidemic when Fajer's article was published) and, thus, have not "dramatically" changed their sexual behavior-specifically by failing to adopt "safesex" techniques. ${ }^{195}$

191. Marta A. Navarto, Interview with Ana Castillo, in CIICANA LESBlANs, supra nole 9, at 122 (quoting Ana Castillo). See also Patrice Gaines-Carter, Festival Will Celebrate the Pride of Being Black and Gay, WASH. POST, May 24, 1991, at Cl (black gays and lesbians express "fear that a public acknowledgement of homosexuality would add to the discrimination they routinely face as blacks in employment and other areas'); Dorothy Gilliam, Coming Out of Closet Is Tougher for Blacks, WASH. POST, July 14, 1980, at $\mathrm{Cl}$ (citing black homophobia and employment concerns as reasons why black gays and lesbians remain in the closet).

192. See Robson, supra note 12, at 182 (criticizing gay and lesbian legal theorists for failing to "effectively counter $\square$ " the perception of gay and lesbian wealth).

193. See, e.g., Duncan, supra note 185, at 406-09.

194. Fajer, supra note 162 , at 561 .

195. In 1990, a study conducted by the National Task Force on ADS Prevention found that nearly one-half of gay and bisexual black men continued to engage in anal intercourse without condoms. See Malcolm Gladwell, Many Black Goys Missing Message on "Safe Sex," Wasu. 
The stated purpose of Fajer's discussion of long-term, monogamous gay and lesbian relationships is to counter the stereotype of "gay people as being empty and promiscuous, devoid of love, warmth, commitment, or stability."196 Fajer, however, fails to consider the impact of racism and class inequality upon this and other "gay" stereotypes. Fajer also does not question whether racism and class inequality may limit, or even preclude, gays and lesbians of color and the poor from escaping negative "gay" constructs or, as a threshold matter, whether these stereotypes even apply to them. Such an examination of race and class, even if only brief and tentative, would have enriched Fajer's analysis because racial and class hierarchies create numerous stereotypes that impact gays and lesbians of color and that inform heterosexual-and gay-society's perception of them. ${ }^{197}$ For example, under racial hierarchy, blacks are considered sexually deviant-promiscuous and predatory. This racial stereotype may interact with and reinforce notions of gay promiscuity. As a result, the "common" assumption of "gay" promiscuity may have particularized effects on people of color. It may, therefore, require an analysis of racism-rather than generalized claims problematizing "gay" promiscuity-to be disarmed.

For example, the negative reaction to Riggs' film Tongues Untied was particularly vitriolic and racially charged. Many of the responses arose after the film's broadcast by the Public Television Service. ${ }^{198}$ For instance, one journalist offered the following editorial:

The program twice declares, "Black men loving black men is the revolutionary act"....

It proceeds to show us how, with a trip through society's sewers. Its actors and the producer, Marlon T. Riggs, preen to rap music, preach in free verse and dance. They also climb

POST, June 14, 1990, at A17. That figure was more than 2.5 times higher than that of the gay male population as a whole. Id. The conductors of the study stated that their findings ademonstrate[ that the traditional methods of promoting 'safer sex,' which have led mam' while gays to change their behavior dramatically, hove failed to reach the black communily." Id. (cmphasis added). The conductors also cited "an urgent need for more culturally specific edueation, risk seduction training and ongoing support ...." Id.

196. Fajer, supra note 162 , at 550 .

197. Gays and lesbians of color face homophobic stereotyping by heterosexuals (of all reces) and racist stereotyping by whites (of all sexualities).

198. See generally Veme Gay, "Tongues" Showing Splits PBS Slallons, NEwSDAY, July 16, 1991, at 46; David Mills, Cry of "Tongues Uniled": Controversial Documentary" on Ga' Blacks, WaSH. POST, July 19, 1991, at Bl; Frank J. Prial, TH Film About Gay Black Men Is Under Attack, N.Y. TIMES, June 25, 1991, at Cl3. 
into bed together naked. ${ }^{199}$

To this viewer, black "rap music," poetry, dance, and sexual diversity are threatening and connected-they all exist within "society's sewers." Together, they render Tongues Untied "the most explicit, profane program ever broadcast by a television network."200 Thus, both racial and sexual bias, instead of an isolated notion of "gay" promiscuity, frame this viewer's disapprobation of the film.

In addition, Patrick Buchanan appropriated images from Tongues Untied for use in a 1992 presidential campaign advertisement. The advertisement criticized then President George Bush and the National Endowment for the Arts, which awarded Riggs a $\$ 5,000$ grant to produce the film. ${ }^{201}$ The advertisement presented men dancing in slowmotion. ${ }^{202} \mathrm{~A}$ voice accompanying the altered scene ${ }^{203}$ announced that "[t]his so-called art has glorified homosexuality, exploited children and perverted the images of Jesus Christ."204 Interestingly, the advertisement presented one of the few scenes from the film that features white men. ${ }^{205}$ Given Buchanan's negative record on issues of racial and sexual subordination, ${ }^{206}$ it is likely that he whitened Tongues Untied to

199. Dick Williams, PBS Fare Tonight Shatters Bounds of Taste, Morality, ATLANTA CONST., July 16, 1991, at 17 (emphasis added). The references in Tongues Untied to "black men loving black men" as a "revolutionary act" are not directly related, or limited, to sexuality-but to broader notions of black male mutual support, collective responsibility, and resistance to negative racial constructs and disempowerment. The phrase is taken from an essay by the late Joseph Beam who characterized "love" between black males as a necessary response to the social and economic "barriers to our loving" and as "an autonomous agenda ... Which is not rooted in any particular sexual, political, or class affiliation, but in our mutual survival." Joseph Beam, Brother to Brother: Words from the Heart, in IN THE LIFE, supra note 9, at 242. 200. Williams, supra note 199 , at 17.

201. See Renee Loth, Buchanan Says Bush Funded Obscene Art; Ad Uses Clip From Film on Gay Blacks, BOSTON GLOBE, Feb. 27, 1992, at 14.

202. See Susan Yoachum, Buchanan Calls AIDS "Retribution," S.F. CHRON., Feb. 28, 1992, at A1.

203. The original scene was not in slow-motion.

204. Yoachum, supra note 202, at Al.

205. This fact was not frequently noted in the media, and when it was, it was dismissed without a discussion of its possible relevance. See, e.g., National Public Radio Transcripls, Mar. 20, 1992 ("You know, the segments of the ad that are shown on the air are not black homosexuals. They're white homosexuals, but that aside ... .").

206. Buchanan has made several statements and supported policies evidencing his animosity toward racial and sexual diversity. During a 1991 interview on This Week With David Brinkley, Buchanan expressed hostility toward the immigration of people of color into the United States: "I think God made all people good. But if we had to take a million immigrants in, say, Zulus next year, or Englishmen, and put them up in Virginia, what group would be easier to assimilate and would cause less problems for the people of Virginia?" Maureen Dowd, 
prevent the public from perceiving his criticism of the film as a product of both racial and sexual intolerance. Buchanan's advertisement visually manipulated society's fear and hatred of a "white male homosexual" in order to suppress black gay cultural expression. Buchanan effectively employed homophobia to marginalize and subordinate black people and to reinforce racism and homophobia. In response, Riggs criticized Buchanan for "exploit[ing] . . . race and sexuality to win high public office."207 Riggs argued that "[b]ecause . . . Tongues $U n$ tied affirms the lives and dignity of black gay men, conservatives have found it a convenient target, despite the awards and popular and critical acclaim it received after its broadcast . . . on public television. ${ }^{3208}$

The homophobic and racist responses to Tongues Untied demonstrate the varying application, diverse impact, and multiple layers of seemingly "common" gay and lesbian stereotypes. The racial complexity of sexual stereotypes may require gay and lesbian legal theorists and civil rights attorneys to challenge racial hierarchy when they analyze and litigate discrimination claims of gays and lesbians of color.

In a subsequent article, Fajer recognizes and explores the dangers of essentialism in legal theory. ${ }^{209}$ He argues that essentialism can be avoided if

[w]e ... tell stories about ourselves, not so much to show how we are representative of our group, but how the society makes

Buchanan's Altemative: Not Kinder or Gentler, N.Y. ThIES, Jan. 15, 1992, at Al; EJ. Dionne Jr., Is Buchanan Courting Bias? Equivocations on Duke Pose Questions About Attiude, WASH. POST, Feb. 29, 1992, at Al. Buchanan also stated that Jack F. Kemp, former Secretnry of Housing and Urban Development and 1996 Republican Vice Presidential candidate, had "gone nstive," mocking Kemp's policies on behalf of people of color and the poor. Dowd, supra. See also (Buchanan called Chinese leader Deng Xizoping an "85-year-old chain-smoking Communist dwarf"; Buchanan referred to Bush campaign stralegist who lobbled on behalf of Japanese trade consortium as a "geisha gitl of the new rorld order"); Dionne, supra (reporting charges of anti-semitism made against Buchanan). Buchanan has also claimed that AlDS is nature's "awful retribution" against gays, Dowd, supra, and has called gays "sodomites" and "the pederast proletariat," Dionne, supra.

Buchanan also emerged as a candidate in the 1996 presidential election. He sparked more controversy over racism following reports that several members of his campaign staff had ties to white supremacist organizations. See Douglas Frantz \& Micheal Janofsky, Bucharan Drowing Extremist Support, and Problems, Too, N.Y. TMES, Feb. 23, 1996, at Al. The co-chair of Buchanan's campaign, Lany Pratt, resigned amidst such allegations. See Richard L. Berke, Buchanan Co-Leader Quits Under Fire, N.Y. TIMES, Feb. 16, 1996, at A27.

207. Marlon T. Riggs, Meet the New Fillie Horton, N.Y. Times, Mar. 6, 1992, at A33. 208. Id.

209. See Marc A. Fajer, Authority, Credibillty; and Pre-Understanding. A Defense of Outsider Narratives in Legal Scholarship, 82 GEO. LJ. 1845, 1853-55 (1994). 
essentializing assumptions about us because of the groups to which we belong. These stories do not purport to show that all members of the group behave a certain way. Instead, they demonstrate that people commonly believe members of a group behave in specific ways . . . 210

Although Fajer acknowledges that people within groups do not necessarily "behave a certain way," he focuses on countering the "common beliefs" about members of these groups $s^{211}$ and on challenging the "monolithic view of gay life." Fi2 Fajer's emphasis on "common beliefs," "essentializing assumptions," and "monolithic views" of "gay" life, and his silence on issues of race, distort the culturally, racially, and class contingent nature of these assumptions and the different ways in which heterosexuals treat and perceive gays and lesbians due to race, class, gender, and other inequities. The notion of gay and lesbian wealth (versus a "common" image of impoverished communities of color) and the collision between Julio Rivera's Latino ("macho") and gay ("effeminate") statuses, for example, demonstrate the shifting nature of these seemingly "essentializing" assumptions and reveal that many of these prejudices may really reflect heterosexual society's negative perceptions of white gays and lesbians (or, possibly, a perception that all gays and lesbians are white). Furthermore, stressing the universality of homophobic assumptions may obscure the fact that these assumptions interact with, rely upon, and reinforce other negative constructs (such as racial stereotypes). ${ }^{213}$ Thus, even if a homophobic society believes "all" gay people are promiscuous, this stereotype may support racial hierarchy and pose particular problems for gays and lesbians of color. Buchanan's use of homophobic images to suppress black gay people and perpetuate racial subordination illustrates this multidimensional aspect of gay and lesbian stereotypes. ${ }^{214}$

The negative assumptions about gays and lesbians rely upon-and are constructed in a context of-racial and class hierarchy. As a result,

210. Id. at 1854 (emphasis added).

211. See id.

212. Fajer, supra note 162 , at 533 n.101 (emphasis added).

213. See Adrienne Rich, Compulsory Heterosexuality and Lesbian Existence, in ThE LESBLAN \& GAY STUDIES READER 239 (Abelove et al. ed., 1993) ("To equate lesbian existence with male homosexuality because each is stigmatized is to deny and erase female reality once again.").

214. The interlocking gender, class, and sexual biases informed the trial court and the Virginia Supreme Court in Bottoms, see supra note 139, further demonstrate the need for a multidimensional deconstruction of homophobic stereotypes. 
they may have particularized racial and class effects. Therefore, narrow theories that stress the "common," "monolithic," or "essentializing" nature of the stereotypes do not adequately depict or confront their complexity. ${ }^{215}$

\section{b. "Core" Experiences}

Even those scholars who generally oppose essentialism in critical legal theory may wish to guard, momentarily, sexuality discourse from racial and class deconstruction. Lesbian theorist Patricia Cain, for example, has criticized feminists for "fall[ing] into the "essentialist trap" by ignoring lesbian reality and attempting "to build a grand or totalizing feminist theory from the perspective of only a few women. ${ }^{2216}$ Cain also recognizes that attempts to develop a "lesbian legal theory" "appear to embrace the concepts of essentialism" that sparked her earlier critique of feminism. ${ }^{217}$ Cain further notes that "[l]esbian perspective and lesbian experience are no more monolithic than woman's perspective and woman's experience."218 Cain, however, feels "much more comfortable challenging the monolithic and universal character of 'woman' than of 'lesbian."'s219 Cain also argues that the category lesbian and lesbian theory "should be protected" from anti-essentialist criticism. ${ }^{220}$ Cain attributes her reluctance to problematize lesbian theory to the following two factors. First, Cain argues that "[t]he category lesbian is too young to be destabilized." ${ }^{2221}$ Second, Cain contends that there is a "core lesbian experience that creates lesbian identity."222 Neither explanation convinces me that lesbian theory should be insulated from a multidimensional analysis.

215. As Audre Lorde has argued:

The white women with hoods on in Ohio handing out $\mathrm{KKK}$ literature on the street may not like what you have to say, but they will shoot me on sight. (If you and I were to walk into a classroom of women in Dismal Gulch, Alabrma, where the only thing they knew about each of us was that we were both Lesbian/Radical/Feminist, you would see exactly what I mean).

.LORDE, An Open Letter to Mary Daly, in SISTER OUTSIDER, supra note 9, at 70:

216. Patricia A. Cain, Lesbian Perspective, Lesbian Experience, and the Risk of Essentialism, 2 VA. J. SOC. POL'Y \& L. 43 (1994) [hereinafler Risk of Essentlalism]. See also Patricia A. Cain, Feminist Jurisprudence: Grounding the Theories, 4 Berk WOMEN's W. 191, 206-07 (1990) (criticizing feminist essentialism).

217. Cain, Risk of Essentialism, supra note 216, at 43.

218. Id. at $43-44$.

219. Id. at 44.

220. See id. at 68.

221. Id. at 56. See generalby id. at 56-61.

222. Id. at 61. See generally id. at 61-69. 
Cain contends that the category lesbian is a "new" construct, appearing in time after both "woman" and "homosexual."2223 Cain observes that the lesbian subject is currently undergoing a "primary deconstruction" aimed at dismantling the negative lesbian image "created by the heterosexist and homophobic patriarchal systems."224 According to Cain, "[t]he positive image of lesbians that is emerging as a result of this first tier deconstruction is still new and fragile, too new and fragile for me to want to start tearing it up under a second tier deconstruction process, into race and class and other chards. ${ }^{.0225}$ Cain compares the "positive" reconstruction of the category lesbian with blacks' attempts, during the civil rights movement, to redefine blackness in order to dismantle its negative, racist construction. ${ }^{226}$

Although I am sensitive to the need for a non-homophobic image of lesbianism, Cain's arguments do not substantiate her claim that lesbian theory should remain isolated-at least for the moment ${ }^{227}$-from racial and class critiques. First, lesbian theory has already undergone significant racial and class critiques. ${ }^{228}$ Thus, Cain's concerns appear untimely. In any event, Cain fails to explain how a narrow construction of lesbianism-freed from the troubling "fragmentation" of racial and class analysis-produces a "positive image" of lesbians. The construction of an "essential" lesbian is likely a "positive" process only for those women whose life experiences happen to fit within its narrow contours. Furthermore, if women of color and the poor must wait to introduce their "second tier" issues of racial and economic injustice into lesbian theory, then the theory will merely replicate dominant structures of oppression by marginalizing poor women, women of color, and issues of racial and class oppression. Therefore, lesbian theory should

223. See id. at 56-57.

224. Id. at 58 (citing CELIA KMZINGER, THE SOCIAL CONSTRUCTION OF LESBIANISM (1987); E.M. ETTORRE, LESBLANS, WOMEN AND SOCIETY (1980)).

225. Id. at 58-59. "Gay man of color" and "lesbian of color" are even newer "postmodem" categories than "gay" and "lesbian," yet I have not argued that these terms or the growing theories surrounding them should escape deconstruction. In fact, I have "invited" and "encouraged" such criticism. See supra note 14.

226. See Cain, Risk of Essentialism, supra note 216, at 59.

227. Cain does not specify when the door should be opened for racial and class critiques within lesbian theory.

228. See supra note 105. See also Steven Seidman, Identity and Politics in a "Postmodern" Gay Culture: Some Historical and Conceptual Notes, in FEAR OF A QUEER PLANET: QUEER POLITCS AND SOCLAL THEORY 118 (Michael Wamer ed., 1993) (discussing racial critiques of gay and lesbian theory and politics and observing that "lesbian women of color played a pivotal role in [1980s feminist anti-essentialism] and implicated the lesbian community in the race issue"). 
not evolve in separate tiers-with racial and class analysis relegated to a secondary, unspecified, future phase of construction. ${ }^{209}$

Finally, Cain does not advance her argument by comparing the "positive" construction of "lesbian" with the redefinition of blackness during the civil rights movement. Despite its attempt to create an affirming image of blackness, the civil rights movement suffered not only from white resistance, but also because black leadership and members of the black community constructed black politics and identity around sexism, homophobia, and "black heterosexual maleness." As a result, "black power" often became an oppressive concept for black lesbians, gay men, and heterosexual women. ${ }^{231}$ Lesbian and gay legal

229. The false image of gay and lesbian wealth and its negalive impact upon gay and lesbian struggles for legal and political equality, see supra pp. 605-08, provides just one reason why lesbian theory should not delay, even for a moment, class and racial analysis. As Ruthann Robson has observed,

Not only does the dissipation of class analysis in lesbian and "queer" legal theory result in a lack of resistance to commodification and the maintenance of heterosexist structures, it also results in our failure to adequately respond to those who advocate our demise....

The portrait of lesbians and gay men as economically privileged serves New Right rinetoric in at least two ways. First, the depiction taps into class resentments and anxieties. Second, economic advantage counters any claim that lesbians and gay men are discriminated against. Yet our oun rhetoric has ofen not effectiveby coumtered these falsehoods.

Robson, supra note 12, at 183 (emphasis added).

230. See HOOKS, AN'T I A WOMAN?, supra note 13, at $94-99$ (describing failures of civil rights movement due to homophobia and sexism within the black community); LORDE, Leaming from the 60 's, in SISTER OUTSIDER, supra note 9, at 134 (same).

231. HOOKS, AnN'T I A WOMAN?, supra note 13, at 98 "While the 60 s black power movement was a reaction against racism, it was also a movement that allowied black men to overtly announce their support of patriarchy."); LORDE, supra note 230, at 137 ("Black romen riere told that our only useful position in the Black Porier movement was prone. The existence of Black lesbians and gay people was not even allowed to cross the public consciousness of Black america [sic]."). Black gay activist Bayard Rustin, for example, organized the 1963 "March on Washington," but this fact was suppressed by leadership in the civil rights movement. See Henry Louis Gates, Blacklash?, The New Yorker, May 17, 1993, at 44 ("because of his homosexuality . . . Rustin was prevented from being named director of the 1963 march"); Gilmore, supra note 12, at 236 (Rustin "was dismissed by some other leaders of the civil rights movement partly because of his sexual orientation"). Gates attributes the closeting of Rustin's role in the march to a fear that his gayness "would be used to discredit the mobilization." Gates, supra, at 44. See also GOMEz, Because Silence Is Costhy, in FORTY-THree SEPTEmbers, supra note 9, at 71 (discussing Rustin's "trorking quielly" in civil rights movement due to fears of white homophobia). While this "accommodation" might have reflected the fear of a white homophobic backlash, it also evolves from a narrow definition of black liberation-one that excludes sexual freedom and the liberty of black gays and lesbians. Had the civil rights movement not been defined around heterosexual needs, black leaders would not have viewied Rustin's sexuality and white homophobia as potential threats to the valldity of the movement. Rather, 
theorists should not repeat these harmful mistakes.

Cain's second reason for temporarily accommodating lesbian essentialism-that a "core lesbian experience" exists-also fails. By "core" experience, Cain "means an experience that is central to who we are as lesbians, an experience that shapes our individual identities in a way that causes us to identify as lesbians, and that unifies lesbians as a category."232

Cain seeks to discover the core lesbian experience despite her seemingly contradictory challenge against feminist essentialism. Cain has argued that the 'category 'woman' should remain open, should be destabilized, so that all women might claim some piece of it. We should not embrace definitions that are so fixed that we exclude some women. Nor should we require a single core experience of all individuals to be included in the class, because there is no core experience that includes all women."233 If lesbians of color and poor lesbians are in fact "women," then inclusion of their racial and class concerns within feminism and the "open" category woman, compels a concomitant openness of lesbian theory and the category "lesbian."

Cain does not reconcile her conflicting positions. Instead, she defines the core of lesbian experience as "the emotional and erotic attraction to another woman and the recognition that this attraction has occurred." ${ }^{3234}$ Cain contends that this moment of self-discovery is

these issues would have been a central part of racial politics and of blacks' resistance to the many ways in which they were marginalized in American society. The suppression of sexual difference to advance purported racial freedom thus reflects an essentialist view that sexuality is separable from and unconnected to racial identity, subordination, and liberation. A multidimensional racial struggle, by contrast, would have exposed and challenged the potential use of white homophobia to advance racist agendas and to subordinate the march. See Kendall Thomas, "Ain't Nothin' Like the Real Thing": Black Masculinity, Gay Sexuality and the Jargon of Authenticity, in REPRESENTING BLACK MEN 66 (Marcellus Blount \& George Cunningham eds., 1996) ("T]he heteronormative vision of racial identity that would exclude the expression of sexual difference among African-Americans does not exorcise but rather incorporates the idcology of white supremacy into the very body of black America, and with it the phobic conceptions of black sexuality as such that white supremacy has always insinuated.") (emphasis in original). Thus, a multidimensional politics would not have required black gays and lesbians to suffer further marginalization in the name of black racial advancement. Cf. Crenshaw, Mapping the Margins, supra note 13, at 1295 ("Although collective opposition to racist practice has been and continues to be crucially important in protecting Black interests, an empowered Black feminist sensibility would require that the terms of unity no longer reflect priorities premised upon the continued marginalization of Black women.").

232. Cain, Risk of Essentialism, supra note 216 , at 62.

233. Id. (emphasis added).

234. Id. at 66 . Cain reasons that "[i]f a lesbian is someone whose emotional and crotic attention is directed toward another woman, then how can any self-identified lesbian not claim 
transformative because "[o]nce we realize the truth of our attraction, we realize our difference from the rest of the world and our lives are different from that moment on."2335

While it is probably indisputable that all self-identified "lesbians" discover they have a "lesbian" intimate attraction, this fact does not eliminate race and class issues from lesbian experience, nor does it render this process the "central" moment in lesbian lives. Indeed, the centrality of this discovery to lesbian experience will likely depend upon the very race and class factors that Cain believes lesbian theorists should, for the moment, ignore. ${ }^{236}$ For example, while some women may "realize [their] difference from the rest of the world" when they discover their lesbian attraction, lesbians who are poor or of color likely encounter marginalization and exclusion long before this moment occurs. ${ }^{237}$ Consequently, their discovery of same-sex intimacy may not be the event that renders them "differen[t] from the rest of the world." Under a multidimensional framework, the homophobic oppression that results from a woman's self-identification as a lesbian is just one important (or "central") aspect of being a lesbian. ${ }^{238}$ Racial and economic injustice are also core and central experiences of lesbian existence 239 and, thus, require immediate analysis in lesbian theory.

Race and class also impact women after they discover their lesbian identity, and these forces create varying lesbian perspectives. Although Cain acknowledges this point ${ }^{240}$ her desire to shield lesbian theory from racial and class deconstruction means that such differences would indefinitely go untold.

Cain correctly states that "[s]ome degree of generalization is neces-

this core experience of having her own attention be so captured?" Id. at 65.

235. Id.

236. See Spelman, supra note 13, at 139 ("Someone might tell me that re have something in common, but even if I agree, I may find that utterly insignificant in terms of my identity and plans for action.').

237. See Gomez, supra note 116, at 938 (stating that when she discovered the isolation that homophobia causes, she "was already struggling with another reality-black skin-that was immensely more devastating in [her] daily life.").

238. See Arriola, Gendered Inequality, supra note 12 , at 133 ("Women are oppressed in many ways, and sexuality is only one of them.").

239. As this Article has argued, these factors also shape homophobia

240. See Cain, Risk of Essentialism, supra note 216, at 69 ("Once a voman discovers that she is a lesbian, she begins to develop a lesbian perspective on life. That perspective varies based on the life that each individual lesbian lives, her specific circumstances, her geographic location, and her economic security."). 
sary to theorize."241 Cain, however, implies that generalizations and a focus on "commonalities" are critical for the construction of a meaningful-even authentic-lesbian theory. She argues that "[a]lthough we certainly know that there must be differences amongst us, lesbian theory must be based on our commonalities. Otherwise, the theory might be interesting, but it would not be lesbian. .242 $^{242}$

I share Cain's opinion that the discussion of racial and class differences among lesbians is an "interesting" project. I do not believe, however, that discussion of these differences merely adds "color" to lesbian theory. Rather, such a discourse is crucial for the construction of a theory that adequately responds to the needs of women of color and the poor. Furthermore, it is not inconceivable to discuss both differences and similarities concurrently, during the same phase of theorizing. ${ }^{243}$ Nevertheless, because gay and lesbian theorists have focused so extensively on sameness, to the nearly complete exclusion of difference, they probably should intensely focus on issues of racial and class diversity in order to fill the holes in their theories.

Concentrating on these differences, moreover, does not neutralize the "lesbian" character of lesbian theory, as Cain implies. Instead, a multidimensional analysis permits us to examine how racial and economic subordination affect poor lesbians and lesbians of color and how an essentialist lesbian theory is itself grounded upon racial and class privileges and the experiences of white and economically advantaged lesbians. Thus, to theorize about the needs of women of color and the poor is no less "lesbian" than the construction of a theory devoid of racial and class analysis, one that likely reflects whiteness and economic privilege.

Multidimensionality, therefore, does not destroy the category lesbian (or gay) or disturb its usefulness as a basis for theorizing. Instead, it merely attempts to make explicit the multiple dimensions (e.g., race and class) of the category and to examine how these dimensions should (and do) affect gay and lesbian legal theory, public policy, and political agendas. ${ }^{244}$

241. Id. at 50.

242. Id. at 61 (emphasis added).

243. Indeed, this Article discusses both. See supra pp. 567-83 (discussing vulnerability of all gays and lesbians to homophobic violence but highlighting differences supplied by racial and class inequality); supra note 95 (recognizing failure of state to protect gays and lesbians from domestic violence but pinpointing possible racial and class differences in this heterosexist practice); supra pp. 609-12 (discussing assumption of gay and lesbian promiscuity but analyzing racial complexity of this stereotype).

244. See PHELAN, GETING SpECIFIC, supra note 105, at 140 ("Coalition cannot be simply the 


\section{B. Essentialist Political Agendas}

Gay and lesbian legal theorists must also carefully analyze the construction of gay and lesbian political discourse because gay and lesbian civil rights litigation and legal analysis often evolve from and parallel arguments advanced and agendas pursued in gay and lesbian political activism. $^{245}$ My examination of gay and lesbian political discourse reveals that it, like gay and lesbian legal theory, fails to engage critically issues of racial and class subordination and privilege. Consequently, gay and lesbian political agendas may conflict with, or fail to include, the goals of gays and lesbians of color. For example, Martin Omelas, a member of LLEGO, the National Latina/Latino Lesbian and Gay Organization, complains that issues of Latino gays and lesbians are often excluded from mainstream gay and lesbian political agendas. ${ }^{246}$ Ornelas expresses an interest in gay and lesbian agendas that include intersecting issues of racism, poverty, and homophobia, such as substance abuse and the lack of educational opportunities among gay Latinos. $^{247}$

strategic alignment of diverse groups over a single issue, nor can coalition mean finding the real unity behind our apparently diverse struggles. Our politics must be informed by affinity, . . - not simply because we are not all alike, but because we each embody multiple, often conflicting identities and locations.") (citing Donna Haraway, a Monifesto for Cyborgs, in FeanNISM/POSTMODERNISM (Linda J. Nicholson ed., 1990)).

245. See Patricia A. Cain, Litigating for Lesbian and Gay Rights: A Legal Hisforj; 79 VA. L. REV. 1551 (1993) (discussing historical nexus between gay political action and civil rights litigation). The politics of homophobia also constrain gay and lesbian legal refom efforts. See, e.g. infra p. 626 (discussing how societal and state homophobia limited efforts to end the exclusion of gays and lesbians from the military).

246. See David James Rose, Coming Out, Standing Oul: Hispanic American Gajs and Lesblans, HISPANIC, June 1994, at 44.

247. Id. Ornelas also injects issues of race, national origin, and, perhaps, nationalism into the debates surrounding the exclusion of gays and lesbians from the military. He

asks Hispanic gays and lesbians to contemplate whether they are prepared to patrol the Mexican border with the National Guard or shoot dohn their lesbian and gay companteros the next time the U.S. government decides to invade Panama, Nicaragus, or Cubs. "Are we expected to join a prior list of issues that does not reflect our realities?"

Id. Accord TOMAI A. MECCA, BETWEen LITTE ROCK AND A HARD PLACE 125-27 (1993) (criticizing gay military movement and arguing that gays and lesbians should instead advocale for civilian employment, anti-poverty, and social welfare programs); Colman McCarthy, Equally for Harriors: A Phory Gain, WASH. POST, May I1, 1993, at ClO (criticizing feminist and gay efforts to join military on grounds that military supports abusive foreign policy); David Tuller, Some Lesbians, Gays Don'l Like Focus on Mnlitary Ban Issue, S.F. Crro.h. July 12, 1993, at A4 (reporting that some gays and Jesbians oppose struggle to end milltary's anti-gay/lesbian 


\section{Race and Sexuality}

As Ornelas' comments suggest, gay and lesbian political agendas may not fully capture the interests of gays and lesbians of color in racial and economic equality. Indeed, several prominent commentators in gay and lesbian politics have even argued that racial and class struggles should have no role in gay and lesbian liberation.

Richard Mohr, for example, urges "gay organizations" not to "build] coalitions with other groups," including "blacks" and "women."248 Mohr contends that such efforts are "[u]necessary and . . . a wasteful drain on the movement."249 Mohr dismisses the expectation of political success from such strategies as "a communist fantasy."250 Mohr also claims that blacks' and women's "groups' fights are not gays' fights. .2251

Mohr seemingly does not contemplate-or he considers irrelevant-the existence of black gay men, black lesbians, and lesbians in general. To these individuals, feminism and antiracism are not "wasteful" frolic. Rather, these political movements are crucial to their "fight" for liberation. Furthermore, if, as Mohr contends, "[c]oming out is the fundament of gays' existence as political creatures, ",252 then gay and lesbian politics must combat racial and class inequality-because racism and poverty constrain gays and lesbians and limit their ability to reveal publicly their sexual identities. ${ }^{253}$

Mohr attempts to defend his narrow conceptualization of gay politics by claiming that "[t]he black movement achieved its political successes without coalitions of the dispossessed."254 Mohr's assertion mis.states history. Although the civil rights movement responded primarily

policies because of military's "history of supporting authoritarian regimes and of helping overthrow elected leaders in Latin America and other regions"). Thus, Omelas' comments regarding the appropriateness of political challenges to the military's ban on gays and lesbians also reflect a conservative/liberal divide within gay and lesbian politics.

248. RICHARD D. MOHR, GAYS/JUSTICE: A STUDY OF ETHICS, SOCIETY, AND LAW 328 (1988). 249. Id.

250. Id. at 329.

251. Id.

252. Id. at 327. For a discussion of the importance and complexity of "coming out," particularly for people of color, see GOMEZ, supra note 231, at 169 ("[A]n individual's need to come out of the closet and name her/himself sexually is not only part of a political strategy, but is, more fundamentally, at the core of accepting adulthood and validating one's own experience.").

253. See supra pp. 608.

254. MOHR, supra note 248 , at 329 . 
to the oppression of black people, much of the activism it generated involved a coalition of black, Jewish, labor, and Latino groups. ${ }^{255}$ Mohr's statement also ignores the failure of the civil rights movement to advance the particular needs of black lesbians, gay men, and heterosexual women-due to its construction of blackness around heterosexuality and maleness. ${ }^{256}$ A narrow "gay" politics further marginalizes gay and lesbian people of color by repeating the errors of antiracism.

Bruce Bawer, a gay cultural critic, similarly challenges the necessity of multilayered gay political struggle. In his excoriating review of Virtual Equality, Bawer argues that sexism, racism, and economic injustice are "issues yes-but gay issues?"257 In addition, Marshall Kirk and Hunter Madsen consider antiracist, poverty, and feminist concerns "superfluous issues" to "gay" liberation. ${ }^{258}$ To Kirk and Madsen, coalitional and multidimensional politics detract from gay political issues. ${ }^{259}$

Mohr, Bawer, Kirk, and Madsen offer a narrow gay politics-a politics devoid of antiracist, poverty, and feminist concerns. This singular politics responds only to the needs of individuals who do not suffer racial, class, or gender exclusion-namely, white, male, middleand upper-class persons. Although these authors contend that race, class, and gender detract—or are separate-from gay politics, the political vision they prescribe rests firmly upon racial, class, and gender

255. See Anthony E. Cook, God-Talk in a Secular World, 6 YALE J.L. \& HuMaN. 435, 450 (1994) ("[T] he liberal coalition of the Civil Rights movement consisted of a precarious alliance of Blacks, Jewish and Christian progressives, and the progressive wings of labor, white riomen's groups, young white college students, and intellectuals."); Kevin R. Johnson, Corvll Rights and Imutgration: Challenges for the Latino Community in the Trenty-First Century, 8 LA RazA LJ. 42, 56 (1995) ("In the 1960s, many achievements of the civil rights movement were gained through a coalition of African-American, labor, Latino, Jewish and other progressive organizations.").

256. See supra pp. 615-16 \& n. 231.

257. Brice Bawet, Under Glass, N.Y. TIMEs, Oct. 29, 1995, § 7, at 24 (emphasis added). Bawer has also expressed a distaste for gay and lesbian multiculturalism. See Bruce BAwER A PLACE at the TABLE 37 (1993) (describing creation of a "queer people of color medis production company" and the publication of an "anthology of lesbian, gay and bisexual Asian/Pacific writers" as "constricting" and as "Balkanization"); id. at 216 (dismissing scholarly research on the links between gender, class, race, and sexuality as "[p]olitically comect and multiculturalist thetoric"). Bawer is not alone in his dismissal of gay and lesbian multiculturalism. See Andrea Lewis \& Robin Stevens, At the Crossroads: Race, Gender and the Gay Rights Bfovement, EThNIC NEWSWATCH, Apr. 30, 1996, at 22 ("There is more resistance to conscious efforts to integrate [racially] the movement and its organizations. It's somehow become vieried as political correciness rather than as a sound strategy."') (quoting white gay activist Eric Rofes).

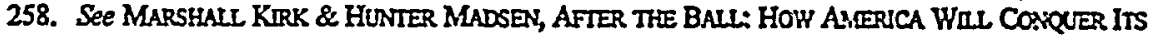
FEAR AND HATRED OF GAYS IN THE 90S 180 (1989).

259. See id. 
privilege. Thus, by portraying coalitional and multidimensional politics as "non-gay," the authors falsely imply that their own essentialist politics is authentic and pure, i.e., not contaminated by race and class; they also deny the racial, class, and gender privileges upon which their own political theories reside. ${ }^{260}$ A multidimensional gay politics that confronts racial, class, and gender subordination is no less valid or "gay" than a politics grounded upon racial, economic, and male privilege.

Although several members of the gay political community explicitly reject the importance of incorporating antiracist and poverty concerns in gay and lesbian politics, issues of racial and class subordination are more often marginalized by omission, silence, and neglect. The white gay political response to the work of white gay photographer Robert Mapplethorpe provides an excellent example of the neglectful absence of racial discourse in gay and lesbian politics. The controversy also illustrates the potential tension between antiracist politics and essentialist gay and lesbian political agendas.

In the late 1980s several museums, members of Congress, and the National Endowment for the Arts attempted to censor Mapplethorpe's work, some of which contained "homoerotic" themes. ${ }^{261}$ Many gay and lesbian activists rallied behind Mapplethorpe, charging the censors with discrimination on the basis of sexual orientation and insensitivity to free expression. ${ }^{262}$ Both prior to and during the conflict with the censors,

260. The authors' denial of the racial basis for their theories perhaps results from a tendency of many whites not to perceive that they even have a "race." HARLON DALTON, RACIAL HEALINo 109 (1996). Dalton explains that "race obliviousness is the natural consequence of being in the driver's seat. We are all much more likely to disregard attributes that seldom produce a ripple than we are those that subject us to discomfort. . . For most whites, race-or more precisely, their own race-is simply part of the unseen, unproblematic background." Id. (emphasis added). See also HOOKS, ANN'T I A WOMAN, supra note 13, at 138 ("[T]he dominant race . . . reserves for itself the luxury of dismissing racial identity while the oppressed race is made daily aware of their racial identity."). Barbara Flagg has also written extensive analyses on "the transparency phenomenon: the tendency of whites not to think about whiteness or about norms, behaviors, experiences or perspectives that are white-specific." Barbara J. Flagg, "Was Blind But Now I See": White Race Consciousness and the Requirement of Discriminatory Intent, 91 MiCH. L. Rev. 953, 956 (1993) (emphasis added). See also Barbara J. Flagg, Changing the Rules: Some Preliminary Thoughts on Doctrinal Reform, Indeterminacy, and Whiteness, 11 Berkeley Women's L.J. 250 (1996); Barbara J. Flagg, Enduring Principle: On Race, Process, and Constitutional Law, 82 CAL. L. REV. 935 (1995); Barbara J. Flagg, Fashioning a Tille III Remedy for Transparently White Decisionmaking, 104 YALE LJ. 2009 (1995); Barbara J. Flagg, On Selecting Black Women as Paradigms for Race Discrimination Anabyses, 10 BERKELEY WomeN's L.J. 40 (1995). These arguments also apply to class, sexuality, and gender. 261. See Alan. Artner, The Eye of the Storm: Mapplethorpe's Unblinking Vision Sparked a Continuing Battle Over Art, N.Y. TMES, Dec. 31, 1989, at C4.

262. Id. See also Christopher Knight, Censorship and Photography's 150th: Controversy Over 
however, political activists in the gay and lesbian community failed to engage in a substantial conversation around the racial issues implicated by Mapplethorpe's work. ${ }^{263}$

A significant dialogue on race did emerge among some black gay activists, however. While they did not align themselves with the censors of Mapplethorpe's work, many black gay men were disturbed by Mapplethorpe's photographic display of black men, which they believed reinforced racist sexual stereotypes. Essex Hemphill, for example, argues that Mapplethorpe's 'work artistically perpetuates racial stereotypes constructed around sexuality and desire. In many of his images, Black males are only shown as parts of the anatomy-genitals, chests, buttocks-close up and close cropped to elicit desire."264 Similarly, Isaac Julien and Kobena Mercer comment that 'Robert Mapplethorpe's catalogue Black Males . . a appropriates the conventions of porn's racialized codes of representation, and by abstracting its stereotypes into 'art, [Mapplethorpe] makes racism's phantasms of desire respectable."265 Pervasive race-sex stereotypes may have dictated that the identity and emotions-elements of personhood-of the black male models in Mapplethorpe's work escape presentation. ${ }^{265}$ Rather, the ste-

Serrano and Mapplethorpe Works Overshadows Obsenvances of the Form's Sesquieentennial, L.A. TIMES, Dec. 17, 1989, at 5; Andrew L. Yarrow, Action Is Condemuned by Artists and Institutions, N.Y. TMMES, July 27, 1989, at C18.

263. By criticizing the absence of a noticeable white gay and lesbian political discussion of the racial aspects of Mapplethorpe's work, I do not intend to suggest that this work should have been censored, nor do I wish to argue that an individual should oppose the content of the work or conclude that Mapplethorpe is "racist" Rather, I wish to argue that by failing to engage in a rigorous discussion of the issues of race and sexual representntion implicated by Mapplethorpe's work, gay and lesbian political leaders marginalized-or trealed as insignificant-issues of race.

264. HeMpHIL, Does Your Mama Krow About Me?, in Cerenones, supra nole 9, at 38 (cmphasis in original).

265. Isaac Julien \& Kobena Mercer, True Confessions: A Dlscourse on Inroges of Black Male Sexuality, in BROTHER TO BROTHER, supra note 9, at 169. Black gay opinion on this issue, however, was not uniform. In fact, one of Mapplethorpe's models, Ken Moody, stated that he did not believe that the artist's work perpetuated the "exploitation" of black men. See Kosank MERCER, Reading RaCial Fetishiom, in WELCONE tO THE JUNGE: NEW POSIMOAS N BLACX CULTURAL STUDIES 197 (1994) (quoting television interview with Moody). Furthermore, Mercer subsequently changed his position and argued that Mapplethorpe and his work do not subordinate, but rather elevate, black men by presenting them in art See id. at 194-204. Moody's opinion and Mercer's flip-flop, however, do not affect my position. I have not argued that Mapplethorpe is racist or that we should condemn his work. Rather, I have only argued that his work presents "issues" of race and that silence on these issues reflects the general marginalization of race in the gay and lesbian political community.

266. See Jane Caputi \& Helen Vann, Imperfect Moments: The Mopplethorpe Debate, S.F. CHRON., Feb. 21, 1990, at A19 (Mapplethorpe's obscuring of the faces of many of his black 
reotypical notion of black male "sexual prowess," presented through phallocentric imagery, assumes centrality. ${ }^{267}$

Thus, black gay criticism of Mapplethorpe's exhibition did not stem from a homophobic drive to censor. Instead, it emanated from an historical concern regarding the negative representation and stereotyping of black male sexuality. Such concerns exist beyond the Mapplethorpe controversy. Julien and Mercer, for example, observe that "in the gay subculture ... [b]lack men ... [are] confined to a narrow repertoire of types - the super-sexual stud and the sexual savage on the one hand, the delicate and exotic 'Oriental' on the other." ${ }^{3268}$ Unless the gay and lesbian community begins to engage in discourse around issues of race and sexual representation, its ability to form political coalitions across racial groups-to the extent that it even considers such coalitions important-will be limited. Mapplethorpe's work provided an excellent opportunity to begin such a dialogue.

\section{Race versus Sexuality}

While the Mapplethorpe controversy exemplifies the potential for conflict around omitted issues of race and sexuality in gay and lesbian communities, the Broadway musical Miss Saigon has engendered direct conflict on these issues. In 1991, the Lambda Legal Defense and Education Fund sponsored a benefit of Miss Saigon, a musical that portrays a romance between a white American soldier and a Vietnamese woman during the Vietnam War. The benefit sparked protests by Asian gay and lesbian groups which believed the play perpetuated stereotypes of Asian men as "villains" and Asian women as "docile" and the sexual objects of white men. ${ }^{269}$ Despite the protests, the benefit took place

subjects reinforces dominant structures of racism).

267. See HeMPHLL, supra note 264, at 38 (in Mapplethorpe's work "[t]he penis becomes the identity of the Black male, which is the classic racist stereotype presented as At in the context of a gay vision") (emphasis in original); Julien \& Mercer, supra note 265, at 169 (in Mapplethorpe's "Man in Polyester Suit' the dialectics of fear and fascination in colonial fantasy are reinscribed by the centrality of the black man's 'monstrous' phallus').

268. Id. at 169. See also Rose, supra note 246, at 44 ("Latino gays are [often] eroticized and ... fetish[ized] by gay white men") (quoting Philadelphia activist and writer Roberto Vasquez-Pacheco).

269. Aileen Jacobson, Protest Planned for "Saigon" Opening, NewSDAY, Apr. 10, 1991, at 57. These protests, however, were not limited to the Asian gay community nor to New York. See Kari Granville, Protests Aside, "Miss Saigon" Show Goes On, L.A. ThMES, Apr. 13, 1991, at F3 (reporting coalition of Asian, theatrical, legal, women's, and anti-racist gay groups opposed to New York Broadway opening); Thomas Walsh, "Saigon" Arrival Brings Storms of Protest and Anger, BACK STAGE, Apr. 19, 1991, at 3 (same); Mike Steele, The Other Side of the Slory; "Miss Saigon" Hits a Nerve Among Asians, STAR TRIB., Jan. 9, 1994, at IF (reporting criticism 
because, as Thomas Stoddard, then the Executive Director of Lambda, explained, the organization "was too far along in ticket sales . . . . Canceling . . . would have resulted in 'a diminution of our program, our ability to fight discrimination directly."'270 Thus, the Asian groups' interests in racial equality threatened to diminish the "fight" against gay and lesbian discrimination-essentially constructed. The true aim of the Asian groups' protests was to challenge negative racial and gender constructs of Asian men and women. Under a framework that views racial liberation necessary for, rather than separate from, complete sexual equality, this antiracist goal does not threaten to "diminish," but rather strengthens, the "fight" against gay and lesbian discrimination. Had gay and lesbian advocates developed a greater consciousness of, and sensitivity towards, issues of racial and gender subordination (and if Asians had greater representation within gay and lesbian organizations), the Miss Saigon conflict would likely have not occurred. ${ }^{271}$

Recently, the most volatile public conflict between race and sexuality has occurred in political discourse surrounding the military's discriminatory policy against gays and lesbians. During the 1992 presidential campaign, candidate Bill Clinton promised to repeal the policy. ${ }^{272}$

surrounding opening of show in Minneapolis).

The Brosdway production of the musical, however, generaled racial controyersy before the Lambda benefit. The controversy arose when the play's director cast a caucasian male is the Eurasian lead character without allowing auditions for the role. See Mervyn Rothstein, Equity Brill Reconsider "Miss Salgon" Decision, N.Y. TmIES, Aug. 10, 1990 at C3. People of color claimed that the decision limited acting opportunities for Asians. See, eg., Paul Winfield, Equity Has Right the First Time, N.Y. TMIEs, Aug. 18, 1990, \& 1, at 25. The goveming board of Equity, an actors' union, voted to reject the musical's Brozdway application. See Rothstein, supra. Equity, however, subsequently reversed its decision amidst charges of discrimination. See Mervyn Rothstein, Equity Reverses "Salgon" Vole and Helcomes English Star, N.Y. TMES, Aug. 17, 1990, at A1.

270. Jacobson, supra note 269, at 57 (quoting Thomas Stoddard). A future shoriing to benefit the Lesbian and Gay Community Services Center of New York City, however, was cancelled after the protests. Id.

271. Vaid comments that gay and lesbian organizations need to pay closer attention to how "messages" are interpreted by members of different racial groups. She opines that had Lambda engaged in such an inquiry prior to scheduling the ARss Saigon benefil, this, possibly, "trould have led them early to conversations with the Asian gay and lesbian community. Such conversations, held while the event was still in the planning stages, could have saved the organization a great deal of pain." VAID, supra note 9, at 304. Eventually, after meeting with Asian groups, Lambda stopped selling tickets to the musical, sent ticket holders a statement from the protestors explaining why they believed the musical affirmed racial stereotypes, and offered ticket holders the opportunity for a refund. Jacobson, supra note 269 af 57 . Stoddard stated that the experience was "unbelievably painful." Id.

272. Michsel Isikoff, Gays Mobilizing for Clinton As Rights Become an Issue, Wast. POST, Sept. 28, 1992, at A1. 
Clinton's announcement, during the early days of his presidency, that he would keep his campaign promise sparked outrage and opposition from military officials, members of Congress, and the public. ${ }^{273}$ Gay and lesbian groups countered this criticism by comparing the military's anti-gay policy to its earlier policies of racial exclusion and arguing that both forms of discrimination are unjust. ${ }^{274}$

Many blacks, particularly heterosexual males, criticized the analogies. ${ }^{275}$ Two observations can be made regarding the black responses to the race-sexuality analogies. First, black responses attempt to engage issues of racial hierarchy that the analogies obscure. Second, black responses stem from homophobia and from a disregard for gay and

273. See, e.g., Peter Applebome, Military People Split Over Ban on Homosexuals: Army Ranks Are Split, As in Society, N.Y. TIMES, Jan. 28, 1993, at A16; Jeffrey Schmalz, Gay Groups Regrouping for War on Mililary Ban, N.Y. TMMES, Feb. 7, 1993, at A6; Eric Schmitt, Months After Order on Gay Ban, Military Is Still Resisting Clinton, N.Y. TMMES, Mar. 23, 1993, at Al; Bernard E. Trainor \& Eric L. Chase, Keep Gays Out, N.Y. TMES, Mar. 29, 1993, at A15. President Clinton eventually retreated from his promise and instead implemented a policy dubbed "Don't Ask, Don't Tell, Don't Pursue." Under this policy, "homosexual conduct" remains prohibited; a statement demonstrating a "propensity" to engage in homosexual conduct (e.g., "coming out") gives rise to a presumption of homosexual conduct (and thus a basis for discharge), and the military will, allegedly, no longer actively seek to discover and discharge gay and lesbian troops. See Able v. United States, 880 F. Supp. 968, 976-77 (E.D.N.Y. 1995), rev'd, 88 F. 3d 1280 (2nd Cir. 1996); Thomas L. Friedman, Accord Is Reached on Military Rules for Gay Soldiers, N.Y. TMMES, July 17, 1993, at Al; Michael R. Gordon, Pentagon Spells Out Rules for Ousting Homosexuals; Rights Groups Vow a Fight, N.Y. TIMES, Dec. 23, 1993, at A1. The military, however, has, reportedly, continued to "ask" some of its members to disclose their sexual orientation. See Philip Shenon, Armed Forces Still Question Homosexuals, N.Y. TMMES, Feb. 27, 1996, at A1 (reporting results of intervicws with service members and review of Pentagon documents).

274. See, e.g., Lisa Keen, The Fears Are Unjustified, WASH. Posr, Jan. 31, 1993, at C7; Art Pine, Gay Issue Quietly Spreads Rifis Through Civil Rights Groups, Lobbyists: High Profile Black and Latino Groups Are on Sidelines in Battle to End Military's Ban on Homosexuals, L.A. Times, Jan. 29, 1993, at A20; Eric Schmitt, Pentagon Aides to Study Option of Segregation for Gay Soldiers, N.Y. ThMES, Jan. 31, 1993, at A1.

275. See, e.g., Lynne Duke, Drawing Parallels-Gays and Blacks: Linking Military Ban 10 Integration Fight Stirs Outrage, Sympathy, WASH. POST, Feb. 13, 1993, at A1; Susan Feeney, Echoes from the Past: Sides at Odds over Parallel of Military Integration, Gay Ban, Dallas MORNING News, May 23, 1993, at J1; David Lightman, To Congressman, Military's Gay Ban Not Like Racial Blas, HARTFORD COURANT, Aug. 16, 1993, at Al; Joe Rogers, Spare Us the Comparisons Between Gays and Blacks, WASH. TMMES, July 29, 1994, at A21; Lena Williams, Blacks Reject Gay Rights Fight As Equal to Theirs, N.Y. TuMES, June 28, 1993, at A1. Black opinion on this issue, however, was not uniform. Many individual blacks-including Coretta Scott King and Jesse Jackson-as well as the NAACP, spoke out against the military's anti-gay policy. See Williams, supra, at A1. In fact, a New York Times/CBS News Poll conducted in February 1993-during the height of controversy surrounding the military ban-indicaled that 53 percent of blacks, compared to only 40 percent of whites, supported legislation guarantecing equal rights for gays and lesbians. See id. 
lesbian rights.

A review of the black responses reveals that blacks are troubled that white gays, by comparing their experiences with discrimination to those of blacks, trivialize the impact of racial subordination and privilege in the lives of blacks and white gays. ${ }^{276}$ For example, Joe Rogers, staff counsel to United States Senator Hank Brown, opines that "to the best of my knowledge, no group in America, save Native Americans, can claim comparison to the unfortunate, aching and miserable experience of slavery and segregation suffered by African-Americans."227 Rogers compares "the behavior of homosexuality, which a person may practice or not" to race, which is immutable. ${ }^{278}$ Rogers asserts that gays and lesbians can, much like "chameleons," "pass through life and selectively shield themselves from criticism, praise, negative attitudes or other perceptions. ${ }^{3279}$ Finally, Rogers relies upon misleading statistics which purport to demonstrate that gays and lesbians have much higher levels of wealth and formal education than the general population and, even more so, blacks. ${ }^{280}$ Rogers concludes that "[ $\left.t\right]$ he obvious differences are key and show a hint of the baselessness of the comparisons." 3281

Rogers, like many other blacks, expresses a concern that analogies between racism and homophobia obscure racism and racial privilege. Some blacks, not unlike other Americans, believe that because white gays can conceal, or even change, their sexual orientation, they, unlike blacks, may evade societal exclusion and take advantage of racial hierarchy. Although their statements dangerously overstate the fluidity of sexual orientation and the wealth of the gay and lesbian community and imply a lack of harm in concealing one's sexual orientation, ${ }^{282}$ these critiques, nevertheless, raise legitimate ${ }^{283}$ and important discussions re-

276. VAID, supra note 9, at 187 ("To a large extent, black resentment at our use of the mcial analogy arises from the persistence of racism, despite the best efforts of a seasoned movement to cradicate it"); Gales, supra note 231 at 42.

277. Rogers, supra note 275 , at A21.

278. See id.

279. Id.

280. Id. See supra pp. $605-08$ (discussing misleading nature of surveys that purport to demonstrate "gay" wealth).

281. Rogers, supra note 275 , at A21.

282. See Schacter, supra note 104, at 299 ("Far from the innocuous safe haven pictured by opponents of gay rights, the closet exacts a high price in selfesteem, emotional health, and access to the community.").

283. There is no conflict in my observation that these responses are at the same time inaccurate and "legitimate." I have also argued that gay and lesbian theory is "essentialist" and that 
garding the racial and economic privileges of white gays and lesbians.

A multidimensional framework, however, could challenge Rogers' essentialist assertion that all gays and lesbians are wealthy and, thus, buffered from subordination. Such a framework could also destabilize Rogers' depiction of the black community as a monolith of poverty and oppression-and heterosexuality. Indeed, despite the existence of class stratification and privilege within black communities, all blacks, including Senate Counsel Rogers, are entitled to civil rights protection due to their vulnerability-albeit varying-to racial discrimination. Although privilege exists in gay and lesbian communities, civil rights protection is necessary to secure the interests of the more marginalized (and even privileged) sectors of these communities.

While some of the black responses to the race-sexuality analogies represent a legitimate attempt to problematize gay and lesbian essentialism, some of them flow from a disapprobation of homosexuality and an opposition to gay and lesbian rights. ${ }^{284}$ Rogers' comments, for example, are blatantly homophobic and antagonistic to gay rights. Similarly, former Joint Chiefs of Staff Chairman Colin L. Powell disagrees with both the analogies and the lifting of the military ban because, he argues, "[h]omosexuality is not a benign ... characteristic such as skin color ... It goes to one of the most fundamental aspects of human behavior."285 Powell conflates homosexual status and "behavior" and concludes that "homosexuality" is "threatening" (i.e., not "benign") and, therefore, incompatible with military service. ${ }^{286}$ Moreover, Lieutenant General Calvin A. H. Waller, a retired army officer, believes that there is a "fundamental difference between being black and being gay" and that "[w] $[w e n$ gays want to openly have their lifestyle foisted upon soldiers and airmen ... I I draw the line."'287 Contextually, these homophobic and essentialist responses illuminate the marginalization and invisibility of black gays and lesbians within black communities. ${ }^{288}$

it marginalizes and subordinates people of color, yet I have not dismissed it as completely wasteful.

284. See VAID, supra note 9, at 187 ("[S]ome of the [black community's] anger at the analogies stems from homophobia"). As this Article demonstrates, a critique of gay and lesbian essentialism need not lead to a wholesale rejection of gay and lesbian rights.

285. Duke, supra note 275 , at Al (ellipses in original).

286. See id.

287. Id. (emphasis added). See also Williams, supra note 275, at A1 ("I believe God loves the individual homosexual, but He hates the homosexual lifestyle.") (quoting Lester James, a Washington, D.C. minister).

288. See generally Cheryl Clarke, The Failure to Transform: Homophobia in the Black Community, in HOMEGIRLS, supra note 9, at 197-208; Marlon Riggs, Black Macho Revisiled: Reflec- 
Gay and lesbian rebuttals to the black critiques of the analogies include acceptance of the anti-essentialist portion of the criticisms, ${ }^{289}$ dismissal or disbelief of black rejection of gay rights, ${ }^{250}$ and general assertions that gays and lesbians, despite the incompleteness of the analogies, still deserve civil rights protection. ${ }^{291}$ In none of these retorts, however, do gay and lesbian activists employ a multidimensional lens to frame issues of sexual subordination. For example, throughout the debates on the military's policy, many activists and other opponents of the policy made narrow appeals to patriotism, equal citizenship, and excellency in service to support their opposition to the homophobic policy. ${ }^{292}$ The possible economic impact of the military's anti-gay and lesbian policy, however, was largely omitted from the debates-despite the fact that "[t]o the poor, the working class, and people with moderate means . . . the armed forces represent a chance for a good education, a steady job, a decent income, and health care benefits."2293 Some racial critics have also indicated that the military's "gay" ban may have a disparate impact upon people of color. ${ }^{294}$ Information on the possible

tions of a SNAP! Queen, in BROTHER TO BROTHER, supra nole 9, at 253-57; Thomas, supra note 231, at 55-67.

289. Williams, supra note 275 , at A12 ("I know I've had privileges that black gay men do not have.") (quoting Thomas Stoddard).

290. Responding to an article reporting black criticism of the analogies, Kevin M. Catcheart of Lambda Legal Defense and Education Fund commented that "[t]he inference that a false dichotomy exists between the black and gay communities is misleading and offensive." Kevin M. Cathcart, Goy Cause Is the Same As Black Cause, N.Y. TIMES, July 10, 1993, at Al8.

291. See id. ("Oppression, no matter what its shape, does harm to all of humanity."); Williams, supra note 275, at Al ("oppression has many faces") (quoting Thomas Stoddard).

292. See VaID, supra note 9, at 173 (Campaign for Military Service, a gay political group formed for the purpose of challenging the military's anti-gay policy, "appealed to patriotism, duty, and gay and lesbian valor"); EJ. Dionne, Jr., Isn't Bigotry A Sin?, WASH. POST, Apr. 27, 1993, at A17 (by challenging military policy "homosexuals are [not] demanding . . . protection for 'bizarre' behavior, but the ability to do something vie admire: To put their lives on the line for their country. There is no more basic expression of full citizenship."); Andrew Sullivan, Gay Values, Truly Conservative, N.Y. ThIEs, Feb. 9, 1993, at A21 ("The values that gays in the military are espousing, patriotism and public service, ere treditional values. And the effect that ending the ban could have on the gay community is to embolden the forces of responsibility and integration."); Tracy WJ. Thome, Senate Hearings Milsor a DLtorted Image; Gays in the Mititary: The Crilerion Should Be Conduct, Just As in the Business Horld, LA. TIMES, May 7, 1993, at B7.

293. VAID, supra note 9, at 153.

294. See Eaton, Homosexual Unmodified, supra note 12, at 72 n38 ("[S]cattered accounts suggest that the military's discharge practices may follow a racial pattem.") (citing RANDY

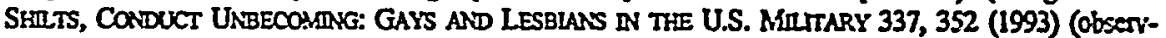
ing that lesbian purge aboard Navy's Norton Sound targeted eight of the ship's nine black Fomen among a total of nineteen women investigated for lesbianism, and noting that three of eight women actually indicted were black)); Lewis \& Stevens, supra note 257, at 22 ("M]f you 
racial effects of the ban was completely missing from the military debates. The absence of an integrated-rather than analogical and external-discussion of racism in the context of the military debates echoes the general lack of knowledge about, animosity for, and ambivalence towards the meaning of race in gay and lesbian politics.

The activists' refusal to challenge racial and class subordination while insisting upon using racial analogies troubles many gays and lesbians of color. Urvashi Vaid has observed that the gay and lesbian community's

use of racial analogies is suspect, coming as it does from a movement deeply splintered over the relevance of racism to the fight against homophobia. Interestingly, even those who believe that the racial justice movement should be completely distinct from the gay rights movement often draw analogies in order to defend gay rights. ${ }^{295}$

Charles Fernandez similarly notes that "it's troubling to witness a white-dominated movement compare its gains and grievances to those of communities of color . ... [O]ne cannot help but appreciate the irony of [sic] white-led movement with limited racial consciousness turning around and appropriating ethnicity and the stigma of race as

watched the media and looked at all of the poster children-the people in the military kicked out because of the ban and filing cases against the military-they were white officers and they were almost all men. But when you look at the numbers, the ban actually disproportionatcly affects enlisted personnel not officers. So there is a class distinction, and it affects people of color and women proportionately more.") (quoting Mike Perez of the Uniled States Students Association, an organization that lobbied against the bar).

295. VAD, supra note 9, at 186. Vaid recounts several instances where her attempts to incorporate an antiracist agenda in gay polities were met with stiff resistarce by white gays and lesbians. See, e.g., id. at 274-306. As this Article argues, such resistance to antiracism and racial diversity is a problem in the gay and lesbian political community. See David W. Dunlap, Three Black Members Quit AIDS Organization Board, N.Y. TIMES, Jan. 11, 1996, at B2 (reporting resignation of three black members from board of directors of Gay Men's Health Crisis, the country's largest AIDS legal and social services organization, due to organization's alleged insensitivity toward people of color and issues of racism); Charles Femandez, Undocumented Aliens in Queer Nation, in LESBLANS, GAY MEN AND THE LAW, supra note 108, at 239 (criticizing racism in the gay and lesbian community); Lewis \& Stevens, supra note 257 (describing racial conflicts within gay and lesbian organizations); Valdes, supra note 158, at 354 n.1252 (discussing dissolution of San Francisco chapter of Queer Nation, a gay and lesbian political organization, due to, among other things, "allegations of racism .....). Vaid is also correct in observing that individuals hostile or opposed to incorporating racial struggle within gay rights may themselves invoke racial suffering in order to defend gay rights. See, e.g., MOHR, supra note 248, at 188-211; BAWER, A PLACE AT THE TABLE, supra note 257, at 85-87. 
legitimating tools."2296 Thus, the lack of an agenda for racial and class equality in gay and lesbian politics may have also influenced the critical black response. ${ }^{297}$

\section{Beyond Analogies}

Clearly, the race-sexuality analogies have failed as a political strategy. This failure results, in part, from the very nature of the analogies. By comparing "blacks" and "gays" (or racism and homophobia), users of the analogies, in addition to omitting black gay people, purport to equate, or to locate similarities between, the historical experiences of the two groups (really, white gays and black heterosexuals). In so doing, they ignore a legacy of racial and class hierarchy-of racial and economic privilege and subordination. Consequently, under the analogies the white gay child of a white slaveowner-or even a white gay slaveowner-occupies the same (or lower) social position as a black heterosexual slave: the former is stripped of his or her racial and class privileges; the suffering of the latter is distorted. Andrew Sullivan, for example, argues that the oppression of (white) gays and lesbians is not

less intense than that against, say, heterosexual blacks. . . . There was no slavery for homosexuals, for example; but even slaves, if they were heterosexual, were occasionally allowed the right to marry the person they loved. That right was often peremptorily taken away, but when it was, the hideousness of the injustice was clear. But that injustice is unavailable to homosexuals, because they haven't even been deemed eligible for the institution of marriage in the first place; they have always been, from one particular perspective, beneath slaves. And they still are. ${ }^{298}$

Sullivan's comparison completely obfuscates the oppression of slav-

296. Fernandez, supra note 295 , at 241.

297. The virtual absence of black gays and lesbians in the military discourse likely results from this narrow focus of gay rights. For example, Perry Watkins, a black soldier riho is one of a few gays to receive a favorable adjudication in a lawsuit challenging the military's antigay policy, see Watkins v. United States, 837 F.2d 1428 (9th Cir. 1988), amended, 847 F2d 1329, different results reached on reh'g, 875 F2d 699 (9th Cir. 1989) (en banc), cert dented, 498 U.S. 957 (1990) (finding military estopped from barring Walkins' re-enlistment solely on basis of sexual orientation), claims that he was not asked by the "anointed Ieadership" of the gay and lesbian community to contribute to the public debate on the ban. Williams, supra note 275 , at Al (quoting Watkins). Watkins also notes that racism within the gay and lesbian community "is a big problem." Id.

298. Sullivan, supra note 145 , at 154-55. 
ery. It also purposefully erases "homosexual" slaves. ${ }^{299}$ Slave marriages, like same-sex unions, had no legal significance. ${ }^{300}$ Thus, from this "particular perspective," white gays and lesbians are not, as Sullivan contends, "beneath slaves." In addition, slave women-whether married or not-were "property" and frequently subjected to sexual assault by white men. ${ }^{301}$ Furthermore, slaves were often compelled to "breed," not to fulfill their own interests in raising children, but to bring economic gain to slaveowners. ${ }^{302}$ Moreover, because slaves and their offspring could readily be sold if their masters so desired, slave families were inherently unstable. Finally, the treacherous institution of slavery persisted for over two centuries in the United States-despite "the hideousness of the injustice." Thus, the concept of a "humanizing" slave marriage seems rather strained and inconceivable. ${ }^{303}$ Accordingly, Sullivan's comparison of white gay experience to slavery distorts the latter's brutality. ${ }^{304}$

In addition to obscuring a history of racial and class hierarchy, the analogies ignore the persistence of racial inequality. By employing the analogies as a plea to obtain civil rights, gay and lesbian political activ-

299. See $t d$. (comparing "homosexuals," for which "there was no slavery" to "heterosexual blacks").

300. See HOOKS, AN'T I A WOMAN, supra note 13, at 43.

301. See id. at $25-43$.

302. Id. at 39-42.

303. Because "married" slaves remained the objects of dehumanization, the social benefits of marriage that Sullivan himself finds most compelling-stable environments for "rearing" children and commitment between two adults, see Andrew Sullivan, Here Comes the Groom: $A$ Conservative Case for Gay Marriage, New Repubulc, Aug. 28, 1989, at 22-were either non-existent or subject to the control and direction of slaveowners, not the slaves.

304. Sullivan is not alone in his comparison of contemporary gay and lesbian experiences to slavery. Several gay and lesbian legal theorists, altomeys and political activists have compared the Supreme Court's decision in Bowrers v. Hardwick, 478 U.S. 1039 (1986) (denying gay male's due process challenge to Georgia's sodomy statute on the grounds that there is no "fundamental right" to engage in "homosexual sodomy"), with its decision in Dred Scolt $v$. Sandford, 60 U.S. (19 How.) 393 (1856) (holding that blacks-whether enslaved or "free"-are not United States citizens and, thus, are entilled to no Constitutional liberties). See, e.g., David Cole \& William N. Eskridge, Jr., From Hand-Holding to Sadomy: First Amendment Protection of Homosexual (Expressive) Conduct, 29 HARV. C.R.C.L. L. REV. 319, 323 (1994) ("Bowers is to the growing gay rights movement what ... Dred Scoll v. Sanford was to the abolitionists."); Gillerman, supra note 104 ("Bowers v. Hardwick should be recognized as the outcomo of a deep and virulent prejudice against homosexuajs, fully equal to the prejudice against blacks exhibited by the Supreme Court in Dred Scott v. Sandford"); Ban on Homosexual Activity Is Upheld, THE RECORD, July 1, 1986, at Al ("Twenty-five years from now, [Bowers] will be viewed as the Dred Scott case of the gay rights movement.") (quoting Thomas Stoddard); Possell Wavered on Sodomy Ruling, CHI. TRIB., July 14, 1986, at A3 ("Opponents of the Bowers raling have compared it to the famous Dred Scolt decision in 1857.'). 
ists and legal theorists imply that blacks, as a group, have attained the political, economic, and legal equality that white gays now seek (e.g., blacks have equality under "the law," but white gays are "beneath slaves").305 Despite some civil rights gains, blacks and whites remain unequal, ${ }^{305}$ and legal remedies to narrow this gulf-at least symbolically-are being rethought, ${ }^{307}$ repealed, $^{308}$ reformed, ${ }^{309}$ and subjected to greater judicial scrutiny. ${ }^{310}$ The analogies overlook this static inequality between blacks and whites and the growing hostility toward public policies enacted to narrow this inequality.

In order to avoid the failures of the analogies, gay and lesbian legal theorists and political activists should advocate sexual equality by addressing the many harms sexual subordination causes. These harms require legal and political remedies for their own sake-without reference to the rights and injuries of black heterosexuals. Furthermore, these harms are not universal but are varied-due to race, class, gender, and other influences. Thus, multidimensionality provides a more effective and accurate framework for discussing these harms. Instead of conceptualizing race as separate from and oppositional to sexuality

305. See Odeara R Neal, The Limits of Legal Discourse: Leaming from the Civll Rights Movement in the Quest for Gay and Lesbian Chyll Rights, 40 N.Y.L. SCH. L. REv. 679, 683 (1996) (discussing the race and sexuality analogies and observing that "[b]ecause the AfricanAmetican civil rights movement has been so metaphorized and removed from its historieal context, the gains of that struggle tend to be exaggerated").

306. For example, in 1992 the poverty rate of whiles and blaciss was $11.6 \%$ and $33.3 \%$ respectively. See Robert Pear, Poverty in U.S. Grew Faster than Population Last Year, N.Y. TIMES, Oct. 5, 1993, at A20 (reporting Census Bureau findings). See generalby ANDREw HACRER, Two NATIOAS: BLACK AND WeITE, SEPARATE, HOSTIE, UNEQUAL (2d ed. 1995) (discussing socinl and economic inequality between blacks and whites).

307. Clinton Plans a Review of Affimative Action Programs, N.Y. ThIEs, Feb. 24, 1995, at A17 (announcing executive review of federal affirmative action programs).

308. B. Drummond Ayres, Ir., Calffomia Baard Ends Preferences in College System, N.Y. Times, July 21, 1995, at Al (reporting decision of Califomia Board of Regents to revole race and gender affirmative action programs for admitting students, hiring professors, and awnding contracts); Pentagon Halts an Affirmative Action Rule, N.Y. ThIEs, Oct 22, 1995, it 22 (reporting revocation of a Department of Defense affirmative action contracting policy for "disadvantaged" and "minority-owned" businesses).

309. Francis X. Clines, Clinton Signs Bill Cutting Welfare; Stales in New Role, N.Y. TMES, Aug. 23, 1996, at Al (reporting enactment of welfare "reform" law that, inter alla, terminales federal guarantee of welfare benefits, shifts spending authority to states in block grant regime, reduces federal welfare funding by $\$ 55$ billion- $\$ 24$ billion of which represents culs in the Food Stamp program-imposes work requirements on recipients, and provides for a five-year lifetime limit on benefils).

310. Adarand Constructors, Inc. v. Pena, 115 S. CL 2097 (1995) (reviewing Congressionally mandated affirmative action programs under "strict scrutiny" rather than intermediate review previously utilized). 
(and, thus, susceptible to comparison), multidimensionality examines the interactions of these statuses to highlight the diverse harms gays and lesbians face. Multidimensionality portrays these harms without diminishing-but rather, acknowledging and emphasizing-the importance of race and other sources of empowerment and disempowerment. Thus, multidimensionality provides a methodology for moving beyond the failed analogies while recognizing-rather than distorting - the true impact of race. ${ }^{311}$

Gay and lesbian legal theory and politics do not evolve from the social realities of Julio Rivera, Venus Xtravaganza, the victims of Dahmer, and the scores of other poor and people of color within the gay and lesbian community. Rather, gay rights discourse arises from an artificial world where racism, sexual subordination, and class oppression resist convergence, or where their convergence is ignored. By excluding issues of racial and class subordination from analysis, gay and lesbian legal theorists and political activists negate the experiences of people of color and the poor and give centrality to the experiences of race- and class-privileged individuals. Consequently, they create harmful conflicts with antiracist agendas and people of color and propose theories that inadequately explain and confront (if at all) the subordination of the poor and racially marginalized. Part IV of this Arti-

311. Professors Jane Schacter and Margaret Russell have written insightful articles on the essentializing nature of the race-sexuality analogies. While Schacter notes that the analogies "erase] 'vertical' differences within a group" (e.g. denies the existence of black gays), Schacter, supra note 104, at 295 , she focuses primarily on how the attempt to equate racism and homophobia "erases 'horizontal' differences across the spectrum of legally protected groups," $i d$., and thereby creates a rigid "singular definition of discrimination," $1 d$. at 298. Schacter concludes, as I have, that the analogies do not "serve... the cause of gay civil rights ...." Id. at 315 .

Margaret Russell recognizes that the analogies may obscure the potency of racism and marginalize gays and lesbians of color. Russell, supra note 186, at 35. Russell, however, believes that the analogies may help build coalitions between people of color and gays and "help to uncover the intersectional experiences of those who are racial and sexual minorities ...." Id. I am not as optomistic on this issue as is Russell. Because gay and lesbian political activists often ignore or even reject the importance of antiracist struggle, it is unlikely that their use of the analogies will lead them to build coalitions with people of color. Furthermore, the "dominant" gay and lesbian community has failed to "uncover" the experiences of gays and lesbians of color directly-by affirmatively seeking to understand their lives and tho general diversity of gay and lesbian existence. Therefore, it is doubtful that the analogies, which actually place a wedge between racial and sexual statuses, will lead them to an integrated understanding of gay and lesbian identity. 
cle urges gay and lesbian legal theorists and political activists to engage in a dialogue regarding the nexus between racial, class, and sexual subordination so that gay and lesbian legal theory and political action may effectively mediate the needs of all gay and lesbian people.

As a Black lesbian feminist comfortable with the many different ingredients of my identity, and a woman committed to racial and sexual freedom from oppression, I find I am constantly being encouraged to pluck out some one aspect of myself and present this as the meaningful whole, eclipsing or denying the other parts of self. But this is a destructive and fragmenting way to live. ${ }^{312}$

312. LORDE, Age, Race, Class, and Ser: Women Redefining Dlfference, in SISTER OUTSIDER, supra note 9 , at 120 . 


\section{CReating A Multidimensional GAY AND LESBIAN LIBERATION DISCOURSE}

\section{A. Confronting the Skeptics}

When I discussed the themes of this Article and the general theme of multidimensionality with colleagues and friends, some of them questioned the need for multidimensional analysis. One such individual raised this issue and suggested, for example, that had the police in the Dahmer and Rivera tragedies acted on sexual bias alone, the same results would likely have occurred. Thus, this person argues that a multidimensional analysis "simply does not matter," or it is just an "interesting," academic enterprise. This criticism is problematic for at least five reasons.

First, as this Article has argued, it is highly unlikely that the results of these scenarios would have been the same if the victims had been white and wealthy and their assailants poor people of color. ${ }^{313}$ Under racial and class hierarchies, poor people of color-particularly black and Latino men-are considered "criminal." Therefore, it is difficult to conceive of them as "victims," rather than predators, and thus worthy of any assistance or protection. ${ }^{314}$ One should not expect this element of racial hierarchy to vanish simply because the individual person of color is gay or lesbian and, therefore, vulnerable to homophobia. Such reasoning implies that sexual orientation eclipses, or otherwise overshadows, race and class statuses and that race and class are irrelevant features of sexual subordination. Accordingly, if the races of the victims and assailants in the Rivera and Dahmer tragedies were inverted, a different police response might have occurred.

Second, legal scholors, as such, must search for "the truth" and present it in their work. To the extent that essentialism distorts reality, it conflicts with this scholarly mission. While essentialism is often necessary in order to contain and focus a discussion, the systematic exclusion of issues of race and class from gay and lesbian legal theory hinders the academic search for truth and renders our theories incomplete and inaccurate. Thus, it is both intellectually dishonest and "unscholarly" to cling to essentialism even if in certain instances the presence of 
multiple forms of discrimination does not affect the outcome of a particular discriminatory act.

Third, by marginalizing issues of race and class, gay and lesbian essentialism replicates patterns of social exclusion-racism, sexism, economic oppression, people of color, women, and the poor remain irrelevant. Scholars who are committed to racial, gender, class, as well as sexual justice, should endeavor not to perpetuate social domination in their work.

Fourth, this criticism centralizes the importance of overt, individual "acts" of discrimination and diminishes the relevance of structural barriers to equality. While an isolated act of discrimination may possibly result from a single form of bias, people's life choices and experiences are undoubtedly shaped by the interaction of numerous structures of power and disempowerment. ${ }^{315}$ Essentialism obscures this reality.

Finally, even if a single source of subordination could have produced the same results in the events detailed in this Article (which I doubt), this fact would not preclude the occurrence of other scenarios that implicate multiple forms of inequality. ${ }^{316}$ When we consider the stark reality of poverty and racism, it becomes troubling-and even impossible-to deny the vulnerability of gays and lesbians of color and the poor to specific harms. For example, poor gay and lesbian people of color face barriers-due to racial and class inequality-in leading openly gay lives and in obtaining physically safe and meaningful opportunities for economic gain. Economic status, in addition to affecting one's ability to "come out" and to lead a life free of violence, impacts a variety of other gay and lesbian legal and political concerns-including access to health care (especially in the midst of an epidemic of AIDS and HIV). Thus, if "coming out" physical safety, and access to healthcare are indeed important issues in gay and lesbian politics and legal equality, gay and lesbian legal theorists and political activists must

315. Indeed, as several critical race and feminist theorists have observed, racial animus (or "discrimination") is not even required for a policy or action to have a negalive impact on an oppressed social group. Rather, the regative impact may result when facially neutral policies perpetuate social inequality caused by past and present acts of discrimination and subjugation. See Ruth Colker, Anti-Subordination Above All: Sex, Race, and Equal Protection, 61 N.Y.U. L. REV. 1003 (1986); Roberts, supra note 13, at 1419.

316. Even if multiple oppressions at times exist in frogments, independent of one enother, I do not believe that analysis of these instances should dominate gay and lesbian theory or preclude multidimensionality-given the prevalence of intertwined oppressions and the fast that we all have multiple identities (e.g., race, gender, sexual identity). In any event, they certainly should not provide the foundation for theories explaining the subordination of gays and lesbians of color and the poor. 
analyze and confront racial and class subordination. ${ }^{317}$

To recognize multidimensional oppression, however, is not to suggest that every negative event in the lives of poor gay people of color results from a plethora of subordinating forces. Rather, it merely acknowledges that in most instances, multiple sources of disempowerment affect their lives in concrete ways. Accordingly, it is imperative that gay and lesbian legal theorists and political activists adopt a multidimensional framework for analyzing and combatting sexual subordination.

B. Sources of Multidimensional Thought: Critical Race Theory and Feminist Legal Theory

Lesbian theorists and a small group of race theorists have introduced anti-essentialism into gay and lesbian legal theory. The most extensive anti-essentialist critiques in equality jurisprudence, however, have occurred in critical race theory and feminist legal theory. ${ }^{318}$ Women of color, and other scholars, writing in these areas have generated a sizeable body of literature that analyzes "intersectional" oppression, specifically racism and sexism, and that exposes the inadequacies of essentialist theories of equality. These critics argue for the development of equality theories that confront multiple forms of disempowerment-theories that respond to the complexity of subordination. Their scholarship has greatly informed this Article and offers gay and lesbian scholars and activists guidance for the task of recentering gay and lesbian political discourse and legal theory away from essentialism and toward multidimensionality.

Kimberle Crenshaw, for example, explores the interactions of race and gender utilizing "intersectionality." Crenshaw states that "[i]n examining the intersections of race and gender, I engage the dominant assumptions that these are essentially separate . . .."319 In addition, Mari Matsuda observes that "working in coalition forces us to look for both the obvious and non-obvious relationships of domination, helping

317. See VAID, supra note 9 , at 271 (gay and lesbian activists must become involved in debates around "raising the minimum wage, welfare reform, AFDC programs, free school lunches, immigration, poverty, and other issues that affect gay and lesbian families and individuals-but do not affect the middle-class people who are most involved in our movement.").

318. See, e.g., sources cited supra note 13.

319. Kimberle Crenshaw, Beyond Racism and Misogyny: Black Feminism and 2 Live Crew, in WORDS THAT WOUND: CrTICAL RACE TFEORY, ASSAUtitve SPEECH, AND tHE FRST AMENDMENT 114 (Gordon et al. eds., 1993) [hereinafter Beyond Racism]. 
us to realize that no form of subordination ever stands alone. ${ }^{2320}$ Matsuda encourages legal scholars to "ask the other question," that is, to examine what multiple forms of subordination a particular act or structure of exclusion may involve. ${ }^{321}$ Similarly, Angela Harris, criticizing "the attempt to extract an essential female self and voice from the diversity of women's experience," argues that the survival of feminist legal theory depends upon its proponents' ability "to root out and examine [their] differences . . . \$322 Harris thus argues that feminist legal scholars must "subvert [legal theory] with . . . accounts of the particular, the different, and the hitherto silenced."323 Finally, Elvia Arriola

rejects the idea of arbitrarily separating out categories to address discrimination in our society. Instead [she] understands discrimination as a problem that arises when multiple traits and stereotypes constructed around them converge in a specific harmful act. Traditional categories then become points of departure for a deeper, more subtle analysis that explores the historical relationships between certain special groups, as well as an individual's experience within each of these groups. ${ }^{324}$

These critics challenge legal scholars and activists to endeavor toward discovering the multiple perspectives of the oppressed by employing "intersectionality,"325 "multiple consciousness," "326 and "holistic"327 liberation theories. They counter, moreover, the notion that we can adequately examine or dismantle any one form of subordination without considering its interaction with other sources of disempowerment. ${ }^{328}$

320. Mari Matsuda, Beside Mfy Sister, Facing the Enemy: Legal Theory Out of Coallilon, 43 STAN. L. REv. 1183, 1189 (1991) (citing SUZANANE PHARR, HOMOPHOBLA: A WEAPON OF SEUSM (1988)).

321. See id. (When I see something that looks racist, I ask, "Where is the patriarchy in this?' When I see something that looks sexist, I ask, 'Where is the heterosexism in this?' When I see something that looks homophobic, I ask, "Where are the class interests in this?").

322. Harris, supra note 13 , at 615 .

323. Id.

324. Arriola, Gendered Inequality, supra note 12 , at 141.

325. See generally Crenshaw, Demarginalizing the Intersection, supra note 13; Crenshaw, Mapping the Margins, supra note 13; Crenshaw, Beyond Raclom, supra note 319, at 111-32.

326. Mari Matsuda, Then the First Quall Calls: Afultiple Consclousness As Jurisprudential Method, 11 WOMEN's RIGirs L. REP. 7, 9 (1989) (multiple consciousness "is not a random ability to see all points of view, but a deliberate choice to see the world from the standpoint of the oppressed').

327. Arriola, Gendered Inequality, supra note 12, at 139-41.

328. See Crenshaw, Mapping the Margins, supra note 13, at 1252; Matsuda, supra note 320 , 
Their scholarship therefore serves as a model for moving gay and lesbian legal theory away from essentialism.

\section{Multidimensionality: An Extension of Intersectional Analysis}

This Article prescribes multidimensionality for gay and lesbian legal theorists. I see multidimensionality as a methodology by which to analyze the impact of racial and class oppression (or other sources of social inequality) upon sexual subordination and gay and lesbian experience and identity and to cease treating these forces as separable, mutually exclusive, or even conflicting phenomena. Multidimensionality exposes the various layers of social power that inform heterosexism and homophobia. Multidimensional analysis also reveals the multiple dimensions of social identity categories and offers a comprehensive framework for conceptualizing sexual subordination that neither "destroys" nor "fragments"329 our lives.

Multidimensionality does not require every piece of scholarship to reflect everyone's personal histories. This is an impossible task. Rather, multidimensionality demands that we make explicit the racial and class (and other) assumptions that undergird our theories, realize these assumptions might (and likely do) limit the application of our theories, strive to discover the vast differences among individuals in oppressed social groups, and learn how these differences should (and do) affect theory and politics. Ultimately, I view multidimensionality as a discursive project aimed at unveiling the complexity of subordination and identity and reshaping legal theory to reflect and respond to this complexity.

The extensive, pre-existing body of anti-essentialist legal scholarship on race and gender and on the general connections between multiple oppressions is most commonly referred to as "intersectionality" by commentators, including Kimberle Crenshaw, its most notable theorist (and, perhaps, founder). Some readers may then wonder why I have chosen a new term-"multidimensionality"- to represent my analysis. I have done so for the following reasons.

First, I believe that the terms "gay," "lesbian," "woman," "person of color," "racism," "sexism," and "homophobia" possess multiple di- 
mensions and contextual layers. "Gay," for example, has racial, gender, and class dimensions. Therefore, "gay" may describe a poor, Latino male, a black, lesbian feminist, or a white, middle-class male-depending on the context of its usage. I also believe that these various dimensions are inextricably and forever intertwined. Multidimensionality accurately captures this reality.

"Intersectionality," by contrast, subtly implies a convergence, particularly in the lives of people of color, of otherwise separate and independent categories. The term "intersectionality" thus suggests a separability of the host of identities and forces that define social groups and social power. I therefore prefer multidimensionality because it more effectively captures the inherent complexity and irreversibly multilayered nature of everyone's identities and of oppression. While the term intersectionality suggests a separability of identities and oppressions, the scholarship in this area has forcefully taught us otherwise. Crenshaw, for example, wishes "ultimately" to "disrupt the tendencies to see race and gender as exclusive or separable categories." views "intersectionality" as a "provisional" or "transilional concept that ... can be replaced as our understanding of each category becomes more multidimensional. ${ }^{3331}$ Viewed in this context, multidimensionality is not a wholly alternative paradigm. Rather it can be seen as drawing upon, extending, and developing intersectionality by pushing legal theorists and political actors toward a "more multidimensional" understanding of social identity categories and subordination.

\section{Reconstructing Gay Rights}

Willing ${ }^{332}$ gay and lesbian scholars and political activists may also

330. Crenshaw, Beyond Racism, supre note 319 , at 114.

331. Id. (emphasis added).

332. Although I hope this Article will educate (and even persuade) gay and lesbian legal theorists and political activists of the need for a broader gay and lesbian liberation, the absence of multidimensional resistance in gay and lesbian politics and legal theory does not result merely from a lack of information on the connections betrieen race, class, and sexual orientation. Rather, racial and class subordination issues are missing from gay and lesbiar liberation discourse because these issues and the people they most directly affect-people of color and the poor-have been historically and continually marginalized and ignored in our society. Narrow equality theories and political resistance also result because theorists and activists fail to acknowledge their own racial and class privileges and how these privileges shape their discourses. Utimately, recognition of privilege and subordination still may not engender changes in theory and politics. See DALTON, supre note 260, at 115 ("It is one thing to recognize that one hes White skin privilege. It is quite another to do something about it."). Multidimensional theory 
adopt multidimensionality and analyze the diverse ways in which race and class frame sexual subordination and how this reality should impact legal analysis. While this Article provides some illumination on the subject, it is intended to serve primarily as the source of a more helpful and accurate jurisprudential paradigm and as an invitation for continued examination and discussion.

The solution to the exclusion of people of color and the poor from gay and lesbian legal theory and political discourse, however, "does not merely entail arguing for the multiplicity of identities or challenging essentialism generally. ${ }^{3333}$ Rather, once gay and lesbian legal scholars and political activists have collected data on the "differences" in gay and lesbian experiences supplied by racial and class hierarchies, they should, ultimately, re-assess their theories and activism and begin to reconstruct them to reflect these differences. ${ }^{334}$

By resting their theories and activism upon difference, gay and lesbian scholars and activists may then conduct a "deeper, more subtle analysis" of power inequality between gays, lesbians, and heterosexuals and within the population of gays and lesbians. For example, a multidimensional framework that examines the links between racial, class, gender, and sexual inequality destabilizes claims that "the gay man" is an "insider." Rather, this supposed "insider" may actually be an "outsider" excluded from structures of power by his race, class, and sexual orientation. Multidimensionality also calls into question the policies and legal remedies hailed by commentators as vital for gay and lesbian equality. Legalized same-sex marriage, for example, may have little impact upon poor gay and lesbian people of color struggling, for economic or other reasons, to conceal their sexual orientation (and therefore hardly thinking about "going to the chapel"). Multidimensionality thus exposes the inefficiencies and domination that result from centering the liberation of all gay men and women around the privileged "insider gay male" experience.

If gay and lesbian legal theorists and activists focus upon difference and upon multiple forms of disempowerment, they will begin the im-

thus cannot answer the difficult political and sociological questions of "whether" and "how" the gay and lesbian community (and society in general) can begin to appreciate, and positively respond to, the need for racial and economic justice, a deeper restructuring of society, and a more egalitarian distribution of power.

333. Crenshaw, Mapping the Margins, supra note 13, at 1298-99.

334. Id.; SPELMAN, supra note 13, at 172 ("[W] should not be surprised if certain assumptions at the heart of much feminist theory will have to be discarded or revised if the experiences of women of color are to be taken as seriously as those of white middle-class women."). 
portant project of including people of color and the poor in gay and lesbian liberation discourse. This process may help ease tensions between white gays and people of color as antiracism is no longer viewed as separate from or threatening to gay and lesbian civil rights. ${ }^{335}$ Finally, a multidimensional gay and lesbian political agenda that seeks to improve the lives and reduce the invisibility of the scores of economically subordinate gay and lesbian people, could destabilize destructive perceptions of a monolithically wealthy (i.e., privileged) gay and lesbian community, one undeserving of civil rights protection.

The process of exploring and giving voice to differences, however, is not without risks. ${ }^{336}$ This process involves an interrogation of repressed, volatile issues-the perpetuation of racial, gender, and class privileges within gay and lesbian communities, the silencing of gays and lesbians of color and the poor, and the inadequacy or extreme limitations of painstakingly planned and well-supported legal and political agendas-such as same-sex marriage. Nevertheless, because these issues limit the effectiveness of gay and lesbian liberation discourse, their discussion must be part of any inquiry undertaken to strengthen it. Only then can we begin to design theories and politics that accurately reflect our multiple needs and experiences. ${ }^{337}$

[S]uddenly she saw her hands and thought with a clarity as simple as it was dazzling, "These hands belong to me. These my hands." Next she felt a knocking in her chest and discovered something else new: her own heartbeat. Had it been there

335. See PHELAN, GETTING SPECIFic, supra note 105, at 145 ("If kie challenge the grand natratives of race, class, gender and sexuality in favor of more loeal and specific analyses, re find that our allies are everywhere.'); Harris, supra note 13, at 615 ("[t]he discovery of shared suffering is a connection more illusory than real; what will truly bring and keep us together is the use of effort and imagination to root out and examine our differences" $\%$. But see Arriola, Gendered Imequality, supra note 12, at 134 ("Giving voice to minority perspectives is a valid, yet delicate and possibly dangerous endeavor."); Matsudb, supra note 320, at 1191 (including "other forms of subordination [within racial struggle] risks breaking coalition").

336. See Arriola, Gendered Inequality, supra note 12, at 134; Matsuda supra note 320, at 1191.

337. As bell hooks opines, "any progressive political movement grows and matures only to the degree that it passionately welcomes and encourages, in theory and practice, diversity of opinion, new ideas, critical exchange, and dissent" BELL hooxs, Censorshlp from Left 10 Right,

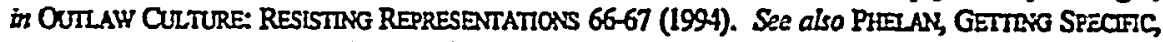
supra note 105, at 145-46 (stating that a "deesentialized identity polities" "privilege[s] no one axis of oppression. Instead, the space is opened simultaneously for a multiplicity of claims and struggies. Without a [universal] theory to tell us what and who belongs where, we herie to begin to talk and listen, to endure conflict and welcome shared achlevements.") (emphnsis added). 
all along? This pounding thing? She felt like a fool and began to laugh out loud....338

\section{CONCLUSION}

The examples of multidimensional oppression presented in this Article will appear extreme to some readers. A sampling of contemporary vital social statistics, however, confirms that in communities burdened by multiple forms of disempowerment, the "wages of sin"-death-are indeed "visible everywhere. ${ }^{1339}$ Although the new and evolving gay and lesbian legal theory has engendered important discussions surrounding power inequality, its proponents' failure to interrogate issues of racial and class subordination makes it impossible for them to propose solutions to the multilayered "sins"-homophobia, racism, economic injustice, and patriarchy-gay and lesbian people face. Ultimately, an essentialist and narrowly focused gay and lesbian liberation de-

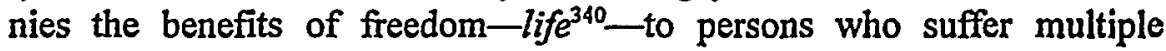
forms of oppression.

While a small number of gay and lesbian activists and scholars in non-legal disciplines are presently constructing a healthy anti-essentialist discourse that continues to develop and unfold, most participants in gay and 'lesbian legal theory have yet to explore substantially how racial

338. TONI MORRISON, BELOVED 141 (1988).

339. BALDWIN, supra note 18, at 20. For example, blacks and Latinos account for ncarly one-half of AIDS cases although they represent only $21 \%$ of the overall population. See NAT'L COAM'N ON AIDS, AIDS: AN EXPANDING TRAGEDY-THE FINAL REPORT OF THE NATIONAL COMMISSION ON AIDS 5 (1993). In addition, the infant mortality rate among blacks is twice the rate for whites, see Death Rates for Minority Infants Were Underestimated, Study Says, N.Y. TIMES, Jan. 8, 1992, at A14 (reporting results of federal study), and among Native Americans and Puerto Ricans, the infant mortality rate exceeds the rate for whiles by $50 \%$ and $40 \%$, respectively, see Malcolm Gladwell, Life Expectancy of Black Males Falls 10 64.9, WASH. POST, Apr. 9, 1991, at A5 (citing Department of Health and Human Services study). Furthermore, due to rising rates of AIDS and homicide, in 1991 the life expectancy of black males declined to 64.9 years, compared to 72.3 years for white men. See id. Also, in 1992, the povcrty rate of whites, blacks, and Latinos was $11.6 \%, 33.3 \%$, and $29.3 \%$, respectively. See Pear, supra note 306, at A20. See also sources cited supra notes $42-44$ (reporting poverty, employment and educational statistics for Latinos). See generally HACKER, supra note 306. Also, I note that several of the writers whose work inspired this Article-Marlon Riggs, Essex Hemphill, and Audre Lorde-suffered untimely deaths.

340. See MORRISON, supra note 338, at 141. This excerpt describes former slave Baby Suggs' passage into freedom. At the moment Baby Suggs enters free territory, she experiences life-her heart starts beating. 
and class subordination and privilege shape gay and lesbian experiences and how these forces should and do inform their analyses. By speaking the theme of multidimensionality into gay and lesbian legal theory, I wish to initiate a dialogue regarding the diversity of gay and lesbian experience, from which a theory more reflective of our social reality might emerge. 
. 